\title{
Ecological Benefits of Mitigation on a Large River Mainstem in an Intensively Mined Appalachian Watershed
}

Eric Mitchell Miller

West Virginia University

Follow this and additional works at: https://researchrepository.wvu.edu/etd

Part of the Environmental Health and Protection Commons, Natural Resources and Conservation Commons, and the Natural Resources Management and Policy Commons

\section{Recommended Citation}

Miller, Eric Mitchell, "Ecological Benefits of Mitigation on a Large River Mainstem in an Intensively Mined Appalachian Watershed" (2011). Graduate Theses, Dissertations, and Problem Reports. 321.

https://researchrepository.wvu.edu/etd/321

This Thesis is protected by copyright and/or related rights. It has been brought to you by the The Research Repository @ WVU with permission from the rights-holder(s). You are free to use this Thesis in any way that is permitted by the copyright and related rights legislation that applies to your use. For other uses you must obtain permission from the rights-holder(s) directly, unless additional rights are indicated by a Creative Commons license in the record and/ or on the work itself. This Thesis has been accepted for inclusion in WVU Graduate Theses, Dissertations, and Problem Reports collection by an authorized administrator of The Research Repository @ WVU. For more information, please contact researchrepository@mail.wvu.edu. 


\title{
Ecological Benefits of Mitigation on a Large River Mainstem in an Intensively Mined Appalachian Watershed
}

\section{Eric Mitchell Miller}

\author{
A Thesis submitted to the \\ Davis College of Agriculture, Natural Resources, and Design \\ at West Virginia University \\ in partial fulfillment of the requirements \\ for the degree of \\ Master of Science in \\ Wildlife and Fisheries Resources
}

\author{
J. Todd Petty, Ph.D., Chair \\ Kyle J. Hartman, Ph.D. \\ J. Steven Kite, Ph.D. \\ Wildlife and Fisheries Resource Program
Division of Forestry and Natural Resources
}

West Virginia University

Morgantown, West Virginia

2011 


\title{
Abstract \\ Ecological Benefits of Mitigation on a Large River Mainstem in an Intensively Mined Appalachian Watershed
}

\author{
Eric Mitchell Miller
}

Large scale surface mining in the central Appalachians causes significant alteration of headwater catchments, and these impacts may be offset through implementation of stream restoration projects. As an example, several habitat enhancement structures (cross-vanes and j-hooks) were constructed along a $13.7 \mathrm{~km}$ section of the Little Coal River as mitigation for mining impacts in the region. The objectives of our study were to: 1-quantify changes in channel morphology, habitat quality, sediment composition, bank stability, biological communities and organic matter processing in response to habitat enhancing structures; 2-relate changes in structural and functional attributes of the Little Coal River mainstem to losses resulting from mining impacts to headwater catchments; and 3-develop a long term restoration monitoring plan for the Little Coal River. The study area included three $1.5-2 \mathrm{~km}$ segments along the Little Coal River mainstem. The upstream segment contained 15 habitat enhancement structures that were constructed between 2005-2006. The downstream segment contained no structures at the beginning of the study (Spring 2009). Twenty structures were then constructed in the downstream segment during late Fall 2009 and Spring 2010. The middle segment contained no structures and served as our reference. Sampling for physical, chemical, and biological attributes occurred seasonally from Spring 2009 - Fall 2010. Our results indicate that the beneficial effects of structures included: increased fish habitat quality and bed complexity, increased substrate diversity, and increased macroinvertebrate biomass and diversity associated with substrate changes. Most measures of fish assemblages did not respond to restoration actions. Poor water quality in the form of elevated sulfates and total dissolved solids (TDS) may be a critical factor limiting ecological benefits of habitat restoration in the Little Coal River. Furthermore, traditional measures of headwater function, such as organic matter decomposition and retention, were not significantly affected by structural enhancement actions. Consequently, effective management of aquatic resources in the central Appalachians must couple habitat restoration projects on larger river mainstems with protection of headwater catchment functions and effective management of water quality at a watershed scale. 


\section{Acknowledgements}

I would like to thank my graduate committee Dr. J. Todd Petty, Dr. Kyle Hartman, and Dr. J. Steven Kite for their assistance during my time at West Virginia University. Particularly, l'd like to give a special thanks to Dr. Petty for his encouragement, insight, and enthusiasm. He truly made this project a joy to work on and his mentoring helped me grow as a person and scientist.

A special thanks to Andy Maraffa, Michael Tincher, Eric Merriam, Alison Anderson, Bill Simmons, and Jason Morgan for their help in the field as well as the laboratory. Without their assistance and the assistance of many others this project would not have been successful.

I am truly indebted to the West Virginia Department of Environmental Protection, not only for the funding of this project, but their commitment and dedication towards it. A special thanks to Dennis Stottlemyer who helped me design the study and brought an enthusiasm that will be unmatched. His insight on mitigation assisted me greatly and the comradery we formed made data collection a pleasure.

Lastly, I would like to thank my family for their support and giving me the motivation I need. Also, I would like to thank Mary Burger for constructive criticism and a different perspective on my research. 


\section{Table of Contents}

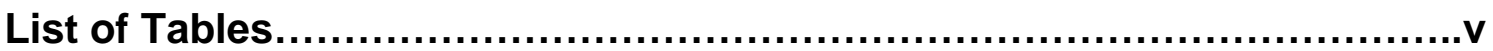

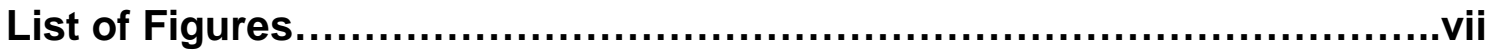

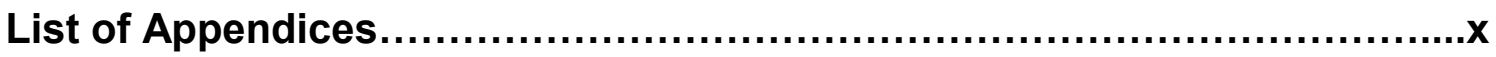

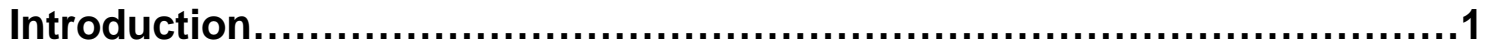

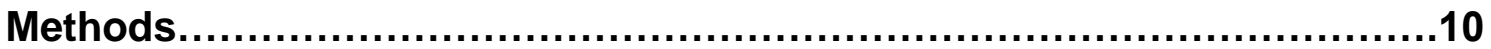

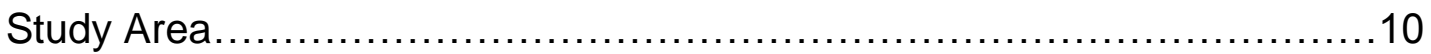

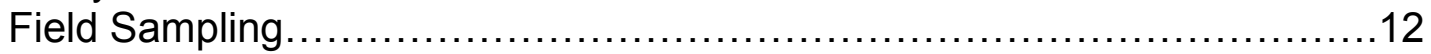

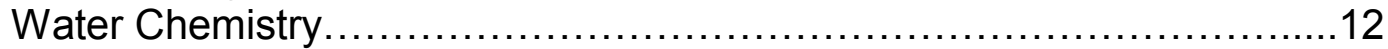

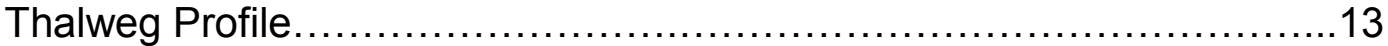

Sediment and Depth Mapping......................................... 14

Cross-section Channel and Longitudinal Profile Geometry................15

Organic Matter Retention............................................... 18

Organic Matter Decomposition............................................ 19

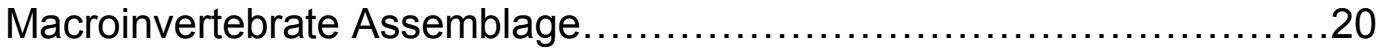

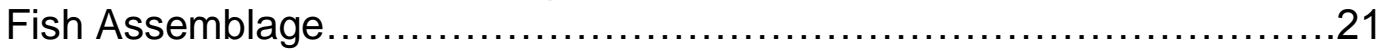

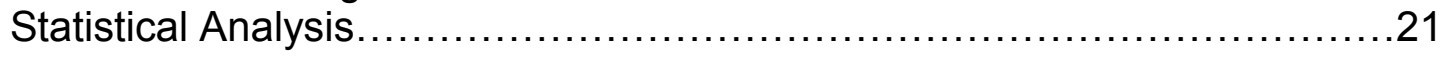

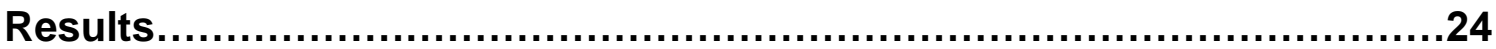

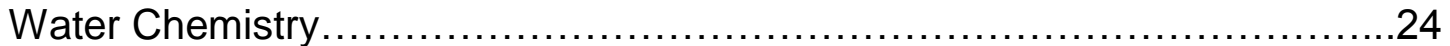

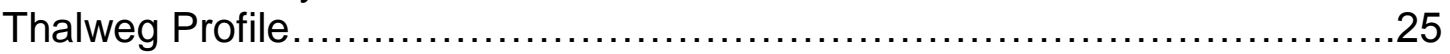

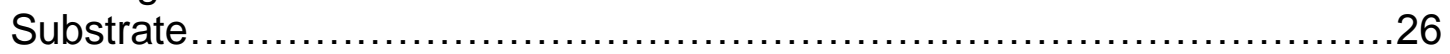

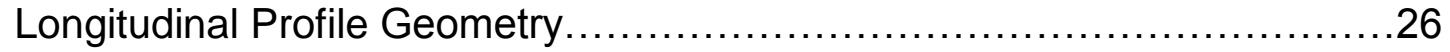

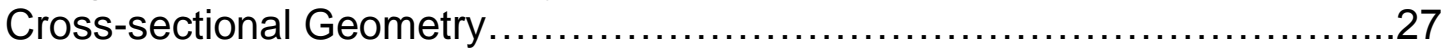

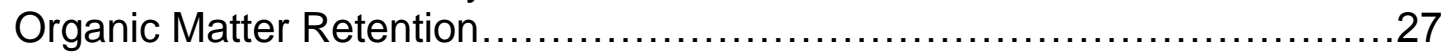

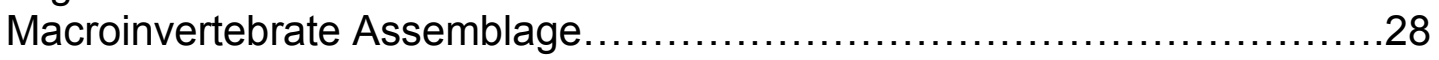

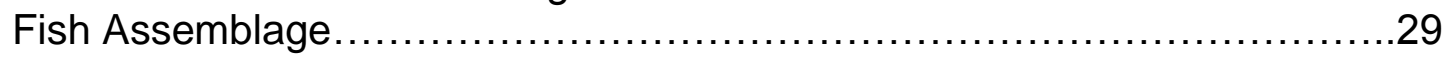

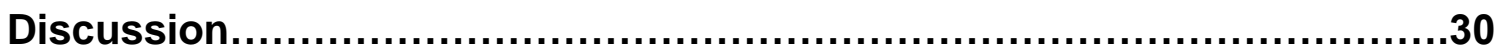

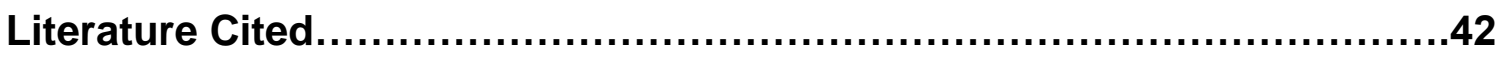

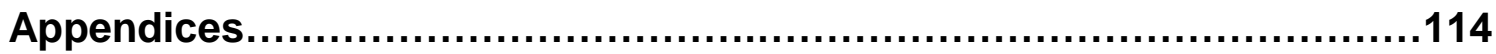




\section{List of Tables}

Table 1: Little Coal River water quality results with respect to year, season, and reach (dots represent missing values)....

Table 2: Mean depth $(\mathrm{m})$, coefficient of variation (CV) of water depth, mean distance to fish cover $(\mathrm{m})$ in 2009 and 2010 of entire study reach and sub-reaches. Standard error is in parenthesis.

Table 3: Percent of substrate type within entire study reach and sub-reaches during pre-construction (2009) and post-construction (2010) period.......75

Table 4: Fishers Exact Test values of substrate type between 2009-2010.

Table 5: Pool attributes (in meters) derived from the longitudinal profiles (mean pool depth was calculated from the monument point at the start of each sub-reach).

Table 6: Pair-wise test statistics for comparisons of cross-sections between years (highlighted values indicate significance differences at the $90 \%$ confidence level).....

Table 7: Global cross section results from $2 \times 3$ factorial analyses of variance (ANOVA) (highlighted values indicate results that are significant at the $90 \%$ confidence level).

Table 8: Tukey's pairwise comparisons results of cross sections (only significant interactions are listed)

Table 9: Retained and not retained dowel rods in each sub-reach and year.

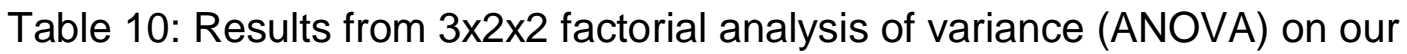
macroinvertebrate community, highlighted values indicate results that are significant at the $90 \%$ confidence level. $m W V S C I$ represent the Modified Stream Condition Index scores; \%EPT is the percent of ephemeroptera, plecoptera, and tricoptera; and total abundance is the abundance of all macroinvertebrates.

Table 11: Tukey's pairwise comparisons results of macroinvertebrate community structure (highlighted values indicate results that are significant at the $90 \%$ confidence level). SS represent sand/silt samples and CG represents cobble/gravel samples. 
Table 12: Fish community structure by year and sub-reach. Percent represents the percentage of the population that comprising that species. Mean \# per $500 \mathrm{~s}$ represents the number of fish collected in 500 of the total 2500 seconds.

Table 13: Dissimilarity analyses based on fish community (highlighted values indicate reaches that are significantly dissimilar at the $90 \%$ confidence level).... 105

Table 14: Fish results of $2 \times 3$ factorial analysis of variance (ANOVA), highlighted values indicate results that are significant at the $90 \%$ confidence level).... 


\section{List of Figures}

Figure 1: Location of study area and upper treatment, lower treatment, and reference reaches.

Figure 2: Diagrammatic representations of habitat enhancing structures

(A. J-hook and B. Cross-vane)

Figure 3: Representative cross-sectional survey conducted in the lower sub-reach (dark line represents the 2009 cross-section before the structure was placed and the light line represents the cross-section in 2010 after the structure was in place; cross-section was conducted "at rootwad.

Figure 4: Change in depth of the lower $13.7 \mathrm{~km}$ of the Little Coal River between 2009-2010.

Figure 5: Depth mapping of the lower $13.7 \mathrm{~km}$ of the Little Coal River in 2009 (lighter colors indicate sallower areas and darker colors indicate the deeper segments.

Figure 6: Depth mapping of the lower 13.7km of the Little Coal River in 2010 (lighter colors indicate shallower areas and darker colors indicate the deeper segments

Figure 7: Distance to nearest fish cover in the lower $13.7 \mathrm{~km}$ of the Little Coal River in 2009 (lighter colors indicate areas with close fish cover and darker colors indicate areas of further fish cover).

Figure 8: Distance to nearest fish cover in the lower $13.7 \mathrm{~km}$ of the Little Coal River in 2010 (lighter colors indicate areas with close fish cover and darker colors indicate areas of further fish cover).

Figure 9: Change in distance to fish cover of the lower $13.7 \mathrm{~km}$ of the Little Coal River between 2009-2010.

Figure 10: Changes in substrate composition between years and sub-reaches.

Figure 11: Substrate mapping of sub-reaches in 2009, lines represent structure locations (lighter colors indicate poor substrate for habitat use and darker colors indicate best substrate type for habitat use)....

Figure 12: Substrate mapping of sub-reaches in 2009, lines represent structure locations (gray indicates sand substrate and black indicates gravel, cobble, and boulder substrates). 
Figure 13: Substrate mapping of sub-reaches in 2010, lines represent structure locations (lighter colors indicate poor substrate for habitat use and darker colors indicate best substrate type for habitat use)

Figure 14: Substrate mapping of sub-reaches in 2010, lines represent structure locations (gray indicates sand substrate and black indicates gravel, cobble, and boulder substrates)

Figure 15: Change in substrate composition of sub-reaches between 2009-2010, lines represent structure locations....

Figure 16: Substrate mapping of the lower $13.7 \mathrm{~km}$ of the Little Coal River in 2009 (lighter colors indicate poor substrate for habitat use and darker colors indicate best substrate type for habitat use).

Figure 17: Substrate mapping of the lower $13.7 \mathrm{~km}$ of the Little Coal River in 2009 (gray indicates sand substrate and black indicates gravel, cobble, and boulder substrates)

Figure 18: Substrate mapping of the lower $13.7 \mathrm{~km}$ of the Little Coal River in 2010 (lighter colors indicate poor substrate for habitat use and darker colors indicate best substrate type for habitat use).

Figure 19: Substrate mapping of the lower $13.7 \mathrm{~km}$ of the Little Coal River in 2010 (gray indicates sand substrate and black indicates gravel, cobble, and boulder substrates)

Figure 20: Change in substrate composition of the lower $13.7 \mathrm{~km}$ of the Little Coal River between 2009-2010.

Figure 21: Longitudinal profile of the upper sub-reach in 2009 (A) and 2010 (B) (Open triangles represent areas where cross-sections were performed).

Figure 22: Longitudinal profile of the reference sub-reach in 2009 (A) and 2010(B)

Figure 23: Longitudinal profile of the lower sub-reach in 2009 (A) and 2010 (B) (the triangles represent areas where cross-sections were performed).....

Figure 24: Dowel rod retention in each sub-reach A) Upper B) Reference and C) Lower with respect to distance traveled (at 920 meters dowel rods had passed through the entire reach unretained) 
Figure 25: A NMDS plot of genus level invertebrate community structure based on substrate type (CG = cobble and gravel, $S S=$ sand and silt substrate, $\mathrm{WVSCl}=$ West Virginia Stream Condition Index, $\mathrm{EPT}=\%$ emphemeroptera, plecoptera and trichoptera, and Abundance $=$ total number of macroinvertabrates)

Figure 26: Macroinvertabrate abundance by year, reach, and substrate 100

Figure 27: Macroinvertebrate habitat weighted abundance by reach and year.101

Figure 28: Mean similarity dendrogram for fish assemblage. The horizontal line is the overall mean between group similarity and the vertical lines are the within-group similarity for each reach and year.... 106

Figure 29: Non-Metric Multidimensional Scaling (NMDS) ordination of fish community similarity matrix (each symbol represents a single site and separation of sites is based on Bray-Curtis distances).

Figure 30: Game fish abundance collected by year and reach with standard error bars..................................................................

Figure 31: Non game fish abundance collected by year and reach with standard error bars.

Figure 32. Total fish abundance collected by year and reach with standard error bars

Figure 33. Shannon-Weiner Index of fish diversity by year and reach with standard error bars

Figure 34. Fish catch per unit effort (fish/minute) by year and reach with standard error bars. 


\section{List of Appendices}

Appendix 1: Genera level macroinvertebrate habitat weighted scores

with respect to year and reach......................................... 113 


\section{Introduction}

Headwater streams are comprised of ephemeral, intermittent, and small perennial systems whose processes sustain downstream aquatic communities (Gomi et al. 2002). These systems serve as the link between the surrounding landscape and larger water bodies and provide vital nutrients for downstream uses (Meyer et al. 2007). Headwater systems are important because they interface the hydrology, geomorphology, and biology of terrestrial and aquatic environments that are, unfortunately, often overlooked in environmental and land use planning (Gomi et al. 2002). Headwaters streams serve multiple functions that are easily negatively impacted by human activities, however the management, conservation, and preservation required as part of sustainable development is highly controversial (Richardson and Danehy 2007 and Bunn and Davis 2000).

Headwater streams comprise a large proportion of the total stream length and are critical areas for nutrient dynamics and habitat for macroinvertebrates, fish, and amphibians (Meyer and Wallace 2001). These systems are partially characterized by the large volume of organic matter relative to stream size (Wipfli et al. 2007). River community infrastructures rely on organic matter inputs to support communities (Wipfli et al. 2007). Headwater processes such as organic matter input, transport, and breakdown are the basis of the food web and support downstream functions (Lake et al. 2007). Headwaters systems comprise greater 
drainage density than larger river systems and are usually confined to steep valleys with different land use types (Gomi et al. 2002). Therefore special care must be taken when protecting and restoring these important headwaters systems (Gomi et al. 2002). In particular, mountain top removal and valley fill (MTR-VF) mining affects numerous headwater streams.

MTR-VF mining in the central Appalachians involves drastic transformations to headwater catchments. These practices alter the topography, surface and substrate properties, and vegetation of these confined systems and can ultimately bury headwater streams (Burns 2005). Alteration of the topography and vegetation negatively impacts hydrologic processes and sediment delivery to downstream systems (Burns 2005). Increasing sediment loading from anthropogenic activity is one problem affecting the quality of American waters and negatively affects fish and macroinvertebrate communities (Sutherland et al. 2002). Excessive sedimentation is higher in disturbed areas such as mine sites, and negatively impacts biota (Zhou et al. 2008). Sediment can be transported downstream in two forms, bed load and suspended load. Bed load sediments, usually comprised of coarser materials such as sand and gravel, are moved along the bottom of the channel, whereas suspended loads are maintained in the water column (Pratt-Situala 2007). Increasing sediment loads negatively affects aquatic communities by decreasing the vital spawning habitat for many fish species and invertebrates by filling spaces among gravel and completely covering habitat (Shaffer et al. 2009). Excessive bed load 
sediment has the tendency to fill pools which allows shallower waters to become warmer in the summer months eliminating important fish refugia (Wiley et al. 2001). Additionally, it covers habitat forcing pool dwelling species to find alternate refugia (Wiley et al. 2001). Excessive sediment is one of the leading causes of stream impairment in West Virginia (Hodel 2004 and Burns 2004). In addition to sedimentation, MTR-VF mining has serious impacts on water quality. The increase of specific conductance is a dominating stressor in streams affected by MTR-VF mining (Hartman et al. 2005, Pond et al. 2008). In addition, specific conductance may be a reliable indicator of mining influences on aquatic ecosystems (Merriam et al. 2011).

The goal of mitigation is to enhance degraded habitats and attempt to improve biological functions (Palmer et al. 2007). During the mining of coal, headwaters are destroyed and ecosystem functions are lost, therefore increasing the need for off-site mitigation, or compensation for lost stream miles. Construction of new stream channels along valley fills is required, but they do not function similarly to the buried stream (Fritz et al. 2010); therefore, off-site mitigation is implemented. Off-site mitigation is the process of mitigating a degraded stream physically removed from the immediately impacted area. For example, the Little Coal River, WV was used as off-site mitigation for headwater stream losses in 2002. This is necessary because the mining process generally buries the stream with overburden, thus precluding any on-site mitigation. 
Stream mitigation is an attempt to recover some lost ecosystem functions in an aesthetic and economical manner (Palmer et al. 2007). This is contrary to stream restoration, which attempts to return a stream ecosystem to its natural historic state after some disturbance. Many people believe that humans cannot recreate natural systems (Hildebrand et al. 2005, Lake et al. 2007) and it is unrealistic to think historic conditions can be re-created by stream mitigation. The fundamental goal of stream mitigation is to provide foundation for natural recuperative processes to build upon, not the immediate re-creation of a system (Palmer et al. 2007). Many of the ecosystem services that are important to society are lost when rivers and streams are degraded such as fresh water inputs, leaf litter inputs, transportation of goods, and recreation (Baron et al. 2002).

Ecosystem restoration involves not only restoration of species and habitat, but also ecosystem processes (Lake et al. 2007). In general, stream health is measured through indexes of biotic integrity (IBI's) or measured against a "pristine" reference condition. (Bunn and Davis 2000). However, less often is the functional integrity and processes (i.e. organic matter retention, organic matter decomposition, downstream facilitation of nutrients) of a stream measured (Bunn and Davies 2000). Functional integrity and process measurements can often reveal otherwise missed indicators of stream health (Bunn and Davies 2000). Lake et al. (2007) argues that ecosystem processes are often neglected in stream restoration. Understanding if there is a relationship between increases in 
biodiversity, through restoration, and increases in ecosystem functioning are necessary to progress the science of stream restoration (Lake et al. 2007).

The goal of stream mitigation projects is to increase ecosystem processes and services in an aesthetic way, while maintain the integrity of the system downstream. (Giller 2005). Restoring processes is as important as habitat and species recovery (Simon et al. 2007). This knowledge has initiated recent efforts to focus on "natural channel design" (NCD) (Simon et al. 2007). NCD uses engineering, geological, and biological principles to improve the hydrology, habitat, and aesthetics of a stream, considering current and future conditions of the watershed and its surrounding landscape (Rosgen 1994).

The NCD approach uses reference streams as the aimed model for restoring and maintaining natural stream functions. (WNRCS 2004). NCD uses bankfull measurements to predict the natural tendencies of the river. Thus, structures designed from natural materials are installed in-stream to stimulate and maintain this behavior. Specifically, the purpose of the structures on the Little Coal River are to facilitate downstream transport of sand, reduce stream channel width/depth ratio, improve structural complexity, increase fish and macroinvertebrate habitat, and improve recreational opportunities (boating and fishing) in the river. These structures include J-hooks, cross vanes, and boulder placements. Altering the width/depth ratio narrows the channel, reconfiguring the morphology of the river at structure locations. The increase of velocity increases 
bedload transport capacity and moves sediment through the structures. The unconsolidated sediment is deposited along the bank below the structure.

Stream and river mitigation may lead to species recovery, improved water quality, increase in recreational activities, and new wildlife refugia (Bernhardt et al. 2005). Over one-third of the rivers in the United States are listed as impaired or polluted, therefore mitigation has to implemented (Bernhardt et al. 2005). Stream restoration is expanding and for the science to grow comprehensive assessments of restoration effectiveness should be performed, however they are rare (McClurg et al. 2007). It is essential that we gather post-reclamation data, so that we can learn from mistakes and resources are used to their fullest potential in the future.

To determine if mitigation or restoration efforts are a success, it is essential to relate the functions of the off-site mitigation to the lost ecosystem functions (Brinson and Rheinhardt 2006). Assessment of restoration work is necessary for management purposes and to improve our understanding of how ecosystems work (Giller 2005). Bernhardt et al. (2005) argued that pre- and post-construction assessments with standardized methods could allow restoration managers to understand which restoration activities are accomplishing their goals and having the broadest impacts; however it is unrealistic to expect that every restoration project will have extensive monitoring. Poorly designed studies have led to much of the uncertainty about the success or 
failure of restoration projects (Jansson et al. 2005 and Roni et al. 2002). Without monitoring, practitioners risk wasting money and never determining which instream enhancement projects and techniques are truly effective (Beechie et al. 2008 and Roni 2005).

There can be many goals for a restoration project, but the most common are enhancement of water quality, improvement of in-stream habitat for fish and macroinvertebrates, restoring riparian zones and bank stabilization (Bernhardt et al. 2007). Although it is unlikely that all the goals will be fulfilled, it is important to monitor mitigation efforts to maximize the likelihood of doing so (Bernhardt et al. 2007). Traditional stream assessment methods can indirectly give us information about biological processes; for example, studying the fish community indirectly assesses substrate because it is directly affected by the presence/absence gravel spawners (Wallace et al. 1982). According to Karr (1999) biological monitoring is essential to identifying biological responses to human actions. Describing the condition of rivers and surrounding landscapes using preconstruction information allows us to diagnose causes of degradation, develop restoration plans, evaluate the ecological threats associated with land use plans in the watershed, or select among multiple development options to reduce river impairment (Roni et al. 2002).

Palmer et al. (2005) discuss five criteria for measuring restoration success. First, the design of the project should incorporate as a guide a concept 
of the healthiest river possible at the site. Second, quantifiable improvements must be made to the condition of the system. Third, the river system's ability to self-regulate must increase as should its ability to cope with disturbance, thus decrease the amount of necessary maintenance. Fourth, damage to the system during construction should be minimized and temporary. Lastly, monitoring must be performed before and after construction and results should accessible to the public (Palmer et al. 2005). These criteria outline the foundation of measuring the success of a restoration project and should be the framework for restoration projects.

Restoration projects require two distinct evaluations (Barmuta 2002). First, restored sites should be compared to their pre-restoration (control) conditions to assess if there was significance in the response variables of interest. Second, restored sites should be compared to target conditions to assess whether the restoration has had biological and functional increases (Lepori et al. 2005). Before beginning a study to evaluate restoration the goals and the objectives should be clearly laid out (Roni 2005). When a restoration plan is implemented there is usually a range of goals, however the objectives are specific and quantifiable (Roni 2005).

There is a demand in the literature for mitigation studies of larger rivers that incorporate before-after-control-impact (BACI) design (Stewart et al. 2009). Most in-stream restoration research has been studied after the construction of 
the structure with little or no pre-construction data and determining success of a project in compromised without this knowledge (Bernhardt et al. 2007). Palmer et al. (2009) performed a comprehensive literature review on studies that quantified the effectiveness of stream restoration. Specifically, they used data from independent restoration projects to determine the success of increasing stream complexity. The reviewed studies ranged from 2-16 years after completion of the restoration project. Palmer et al. (2009) found that the overwhelming majority of stream restoration projects ( 83 of 93 total) produced no significant change in habitat complexity.

Other fields in restoration ecology have adapted $\mathrm{BACl}$ design. Literature on wetland restoration and mitigation has brought $\mathrm{BACl}$ study design to the forefront (Malcom and Radke, 2008, Conway et al., 2010, Palik and Kastendick, 2010). This method gives researcher insight to the full functional lift of a mitigation project. Where most stream mitigation monitoring projects use first year data collection as baseline data, $\mathrm{BACl}$ allows researchers to know preconstruction conditions. Without using BACl study design the project may increase in response however never truly determining project success because pre-construction conditions were unknown.

As a part of off-site mitigation for previously permitted surface mines in the region, 15 in-stream habitat enhancing structures have been installed in the Little 
Coal River for $\sim 5$ years. In 2010 approximately 20 more structures were installed. The objectives of our current study were to:

1) To quantify changes in channel morphology, habitat quality, sediment composition, bank stability, biological communities and organic matter processing to habitat enhancing structures constructed in the Little Coal River;

2) To relate changes in structural and functional attributes of the Little Coal River mainstem to losses resulting from mining impacts to headwater catchments; and

3) To develop a long term management/restoration/monitoring plan for the Little Coal River.

\section{Methods}

Study Area

The Little Coal River watershed drains approximately $994 \mathrm{~km}^{2}$ of mountainous terrain in Lincoln, Boone, and Kanawha Counties in West Virginia and is $\sim 56 \mathrm{~km}$ long. Although mining has occurred in the watershed for more than a century, several mines in the Little Coal River watershed are currently active with a total of more than 1780 hectares of valley fills. Historically, the river was used to barge sand from quarries upstream and used for cleaning coal pre- 
1972. A highway was constructed from $1972-1973$ that follows $\sim 26 \mathrm{~km}$ of the Little Coal River mainstem.

Currently, the Little Coal River has relatively low productivity, caused by excess sulfates and poor habitat quality (Bodkin et al 2007). The river is also listed on the United States Environmental Protection Agencies 303(d) list for fecal coliform. Approximately $12 \%$ of the coal river watershed has previously been mined or is currently being mined. R.E.I Consultants has estimated that $\$ 700,000$ has been spent on the Little Coal River as of 2009 and the WVDEP estimates that $\$ 3,000,000$ will be spent by the end of the entire Little Coal River project (Steelhammer 2010). The WVDEP has plans to install structures upstream to Danville, WV, over the next 10 years, which would span an addition $20 \mathrm{~km}$.

The specific focus of this study is the last $13.7 \mathrm{~km}$ section of the lower Little Coal (Figure 1). The lower Little Coal River and was delineated into three segments: 1 - an upper segment where $3 \mathrm{~J}$-hook and 12 cross vane structures were present prior to beginning the study; 2 - a lower segment where 20 cross vane structures were installed in the summer of 2010; and 3- a middle segment which represents a reference reach, where no structures were constructed. Construction of the lower reach structure was completed in late June 2010. Each of the reaches contained a representative sub-reach that was approximately 40 times the mean stream width (Freund and Petty 2007; Merovich and Petty 2007). 
The three segments started and ended at the head of a riffle. The length of the representative upper, reference, and lower reaches were 915 m, 1278 m, and $1433 \mathrm{~m}$, respectively. These sub-reaches were used for finer scale analysis of substrate type, quantification of organic matter retention, and detailed mapping of the longitudinal profile of the stream channel.

\section{Water Chemistry}

Whole water samples were collected twice a year in the spring and fall of 2009 and 2010 from each of the study reaches. Water samples and field measurements were collected in accordance with standard operating procedures of the West Virginia Department of Environmental Protection Agency (Petty et al. 2010). While collecting water at each site field water quality measurements were collected using a multi-parameter YSI 650 unit fitted with a 600XL snode (Yellow Springs Instruments, Yellow Springs, OH, USA). The YSI measures temperature (ㅇ), $\mathrm{pH}$, specific conductivity ( $\mathrm{uS} / \mathrm{cm})$, dissolved oxygen $(\mathrm{mg} / \mathrm{L})$ and total dissolved solids $(g / L)$.

Twice a year whole-water samples (i.e., unfiltered) and filtered samples were collected within each reach for laboratory analysis. Both of these samples were collected in the middle of the river at the approximate mid-depth of the river. The unfiltered sample was collected by holding a pre-rinsed $500 \mathrm{~mL}$ bottle under water until all the air within the bottle is replaced with water. The cap was then placed onto the bottle under water to ensure that air does not enter the container. 
The filtered sample were collected with a pre-rinsed Nalgene polysulfone filter holder and receiver using fitted cellulose membrane discs ( 0.45 um). Once the filtered sample was collected it was treated with $5 \mathrm{~mL} \mathrm{1:1} \mathrm{nitric} \mathrm{acid} \mathrm{to} \mathrm{prevent}$ the metals from precipitating out of solution. Both samples were kept at $4^{\circ} \mathrm{C}$ until their arrival at the laboratory ( $<24$ hours).

The National Research Center for Coal and Energy at West Virginia University analyzed all water samples. The unfiltered sample was used to estimate alkalinity, acidity, total phosphorus, nitrate, nitrite, ammonium, and sulfate. The filtered sample was used for the total dissolved parameters: aluminum, barium, cadmium, calcium, chloride, chromium, cobalt, copper, iron, magnesium, nickel, selenium, sodium, and zinc.

\section{$\underline{\text { Thalweg Profile }}$}

A thalweg profile is a method for obtaining in-stream measurements of habitat complexity (Petty et al. 2001, Merriam et al. 2011) and was conducted over the entire 13.7 kilometers of the river in 2009 and 2010. Sampling stations were spaced every $1 / 2$ mean stream width along the thalweg. At each sampling station, the following information was collected: channel unit type (sensu Petty et al. 2001), water depth, substrate category (silt, sand, gravel, cobble, boulder, or bedrock), distance to nearest fish cover, and distance to nearest retentive feature. Fish cover is any object large enough to conceal a $20 \mathrm{~cm}$ fish and retentive features are objects large enough to retain organic matter during flows 
that fill the active river channel (i.e., "normal high water events" not "bankfull event").

\section{Sediment and Depth Mapping}

One of the major purposes of the habitat enhancing structures is to facilitate transport of sand and silt through constriction of channel flow. In order to assess the effectiveness of the structures in affecting sediment composition, water depth and sediment composition maps of the entire $14.7 \mathrm{~km}$ study area were constructed. Our assessment was performed by comparing 2009-2010 substrate maps. Although, the reference reach was located between our treatment sites, we will there was sufficient distance between reaches. To construct the maps, two teams of two people started on opposite sides of the river. Five measurements by each team were taken as they walked at a $45^{\circ}$ angle from bank to bank. The teams recorded sediment type and depth measurements at evenly spaced points along that transect. The sediment types were: silt, sand, gravel, cobble, and boulder. These points were at left bank, middle left, center, middle right, and right bank. At each of the bank measurements a GPS point was taken to assist in the map building.

Finer scale sediment and depth maps were created in representative upper, reference and lower sub-reaches, which were $915 \mathrm{~m}, 1278 \mathrm{~m}$, and 1433 $\mathrm{m}$ respectively. These maps allowed us to see localized details that may not be seen in our larger maps. Three people walked the river recording a measurement 
every 3-4 m. Each person has a section of the river, either the left bank, center, or right bank. Within each $1 / 3$ of the river, the individuals synchronously moved to obtain a representative sample spanning the width of their section. At each point depth and sediment type measurements were taken. These data produced a finer scale of substrate change within our representative sub-reaches.

Substrate data allowed the creation of the maps in ArcMap 9.3. We used the kriging ordinary method, an interpolation technique in which surrounding values are weighted to derive a predicted value for unmeasured locations, for sediment type, depth, and distance to fish cover (ERSI 2010). Because the one goal of the structures is to facilitate downstream transport of sand; entire river and sub-reach maps were then reclassified into "sand" and "not sand" maps. Our "not sand" category includes gravel, cobble, and boulder measurements and our "sand" category includes sand and silt. Due to the low count of silt measurements they were combined with sand for all analyses. These maps were then compared to one another in the raster calculator to estimate the change in substrate type and visualize changes in substrate type.

\section{Cross-Sectional Channel and Longitudinal Profile Geometry}

Cross-section surveys and longitudinal profile surveys were conducted in summer 2009 (prior to in-stream structure constructions in the lower segment) and summer 2010 (following in-stream structure construction in the lower 
segment) to provide information on channel geometry within the three study segments of the Little Coal River. If multiple surveys are conducted sequentially over time, then they can be used to quantify changes in the channel morphology and relative channel stability over time (Fraley et al. 2009). The surveys show changes in wetted channel, bankfull channel, and floodplain widths and depths over a given period. All cross sections and longitudinal profiles were bench marked with $80 \mathrm{~d}$ galvanized nails into large trees to maintain stations over time. Channel surveys were conducted using a Spectra LL300 automatic-leveling rotary laser level and receiver (Trimble Navigation Limited, Sunnyvale, Ca.). Eighteen inch rebar stakes were placed into the terraces and bank at bankfull height and flagged, so the study can be duplicated at the exact locations for years to come.

Described by Rosgen (2006) a J-hook consists of natural materials. A large tree or vane arm is attached to the bank facing upstream. The vane arm root wad is set at $1 / 2$ bankfull height. The arm placed at $\sim 30^{\circ}$ (facing upstream) from the bank outwards occupying $1 / 3$ of the river. The "hook" portion of the structure consists of boulders that occupy another $1 / 3$ of the river, leaving the last $1 / 3$ of river free flowing. A cross-vane structure is very similar to the J-hook however the remaining $1 / 3$ of river that was free flowing is occupied by another vane arm. In addition to the second vane arm the cross-vane has another series of boulders creating a second "throat" and between the two throats is a scour pool (Figure 2). In the upper reach, five cross sections were taken at two existing 
structures (total of 10 cross-sectional surveys). At each structure the cross sections the rootwad of the vane arm was our starting point. From that point we conducted cross sectional surveys at $30.5 \mathrm{~m}$ upstream, $15.25 \mathrm{~m}$ upstream, 15.25 $\mathrm{m}$ downstream, and $30.5 \mathrm{~m}$ downstream.

Within the reference reach (i.e. middle segment) a cross-section survey was conducted within a representative pool and a representative riffle. In the lower section three cross-sections were conducted at three proposed structure areas pre-construction. These were taken at $30.5 \mathrm{~m}$ upstream, at the proposed root-wad location, and $30.5 \mathrm{~m}$ downstream. All cross-section surveys were conducted from terrace to terrace. A bankfull measurement and edge of water measurement were taken on both sides of the river. The cross sections were conducted pre- and post-construction so morphological changes due to the habitat enhancement structures can be seen.

Using the Spectra LL300 automatic-leveling rotary laser level and receiver longitudinal profiles were taken within each of the three study segments. The longitudinal profiles were conducted from the head of a riffle to the head of a riffle along the thalweg for a minimum length of 40 times the mean stream width. In the upper section the longitudinal profile was $915 \mathrm{~m}$, the reference reach profile was $1280 \mathrm{~m}$, and in the lower section the longitudinal profile was $1432 \mathrm{~m}$. The longitudinal profiles are different lengths due to the lack of riffles. These profiles allow use to visualize the changes in morphology the structures have made. 
Profiles were created in The Reference Reach Spreadsheet and in accordance with the program they are displayed in feet (Mecklenburg and Ward 2004).

During the construction phase of the structures a deep pool is dug immediately downstream of the second throat of the structure. The substrate is then removed and placed on the outside of the vane arms (this area was once part of the stream channel). Our "at rootwad" cross section fell directly at that point and therefore we were able to see the dramatic difference in cross-section (Figure 3).

\section{Organic Matter Retention}

Organic matter retention rates were quantified within representative reaches within the upper, middle and lower segments. Organic matter retention is the rate at which organic matter (leaves and sticks) are removed from transport and stored within a local stream reach (Entrekin et al. 2008). Stream retention is an important function needed to maintain the local food web and is recognized as a key headwater stream function that may be lost as a result of large scale surface mining (Minter 2009). Within each of our three reaches the first $915 \mathrm{~m}$ section of our longitudinal profile selected to conduct the retention survey. Every $92 \mathrm{~m}$ of the $915 \mathrm{~m}$ was flagged and fifty painted dowel rods were released at the upstream end of the reach. The dowel rods were spread across the full width of the stream and left for 40 minutes. After the 40 minute waiting period, the entire reach was walked, and the locations of the dowel rods were recorded with 
respect to the $92 \mathrm{~m}$ section within which it was found (Minter 2009). We performed our retention study once in 2009 and once after construction in 2010. This data was used to estimate the cumulative distance traveled by each dowel rod and the percentage of dowels retained within each $92 \mathrm{~m}$ sub-section.

\section{Organic Matter Decomposition}

Because organic matter decomposition is an ecological function that may be lost when headwater streams are impacted by mining, we attempted to use leaf litter packs to measure the capacity of this function in the Little Coal River. The leaf packs consist of mesh bags $(10 \mathrm{~mm})$ that were filled with $10 \mathrm{~g}$ of pin oak (Quercus palustris) leaves. Three $10 \mathrm{~g}$ bags were combined to make one leaf pack. Leaf packs were placed into the stream using rebar or existing stable structures (i.e. roots or boulders) at each site. The leaf packs were left in the stream for a period of 45 and 90 days. There were two sites in the upper section, both associated with a structure, two sites in the reference reach, and two sites in the lower reach, pre- and post-construction of a structure. At each site leaf packs were placed in three different velocities: slow, moderate, and fast. Within each velocity regime there were six leaf packs. After 45 days, three leaf packs were removed from the river and take them to the lab for analysis and the other three packs were left for 45 more days. However due to the variability and magnitude in flow of this size river, high flow events washed out our leaf packs and data was never collected. 


\section{Benthic Macroinvertebrate Assemblages}

We sampled benthic macroinvertebrates in our three representative reaches in the spring and fall of 2009 and 2010. In each reach a total of 9 benthic samples were collected from two different types of habitat: sand-silt and cobble-gravel. A total of 27 samples per substrate type per year was collected. We sampled each substrate type using a kick net with a 500um mesh and dimensions of $335 \times 508 \mathrm{~mm}$. Within each area a $0.25 \mathrm{~m}^{2}$ region of stream bed was disturbed to insure that the majority of the macroinvertebrates are collected. Nine samples were collected from each habitat type within each reach; each sample is comprised of three "kicks". A kick consists of placing the net beneath a riffle and vigorously disturbing the substrate. After the completion of three kick samples from one habitat type, the contents of the kick net were preserved in $95 \%$ ethanol. The net was thoroughly cleaned and then the next habitat type will be sampled in the same manor.

Once in the lab, samples were first rinsed into a $2 \mathrm{~mm}$ sieve, the contents of which were all identified. The wash from the $2 \mathrm{~mm}$ sample was rinsed through a 250 um sieve. The 250 um sample was then split into $1 / 8^{\text {th }}$ using a plankton splitter. The remaining $1 / 8^{\text {th }}$ sample was identified, this allowed us to estimate the total number of bugs $2 \mathrm{~mm}-250$ um in size. Macroinvertebrates were identified to the genus or the lowest possible level using Peckarsky et al. (1990) and Merritt and Cummins (2008). 


\section{Fish Assemblages}

Fishes were collected using an electro-fishing boat provided by the West Virginia Department of Environmental Protection. Fish were sampled with respect to structures, proposed structure locations, and channel units. The electro-fishing was quantified with respect to time. Within each study reach, five $92 \mathrm{~m}$ sections were sampled in mid-August of 2009 and 2010. In the upper section five in-stream structures were sampled. In the reference section, two glides, a riffle, a pool, and a run were sampled. In the lower section, five areas prior to structure construction (2009) were sampled and then again in 2010 after construction. We used 500 seconds as our target shock time, with the concentration being on the structures themselves, where applicable, and the banks. Species type, total length, and weight were recorded for all fish. Fish sampling was conducted in the summer 2009 and 2010 in the same locations.

\section{Statistical Analysis}

The central purpose of our analysis was to determine the effect of habitat enhancing structures on stream habitat quality and biological attributes. All analyses were performed in the program $R$ ( $R$ Development Core Team 2008), and a significance level of 0.1 was used in hypothesis testing. An alpha level of 0.1 was used because of the variable nature of the aquatic systems and low sample size (Al-Chokhachy et al. 2010, Miller et al. 2010 and Bryant et al. 2004). 
Contingency table analysis was performed to determine changes in substrate composition between 2009 and 2010. Due to low counts in the boulder category, Fisher's Exact Test was used.

We used paired t-tests on cross-sectional survey data to test for differences in channel geometry between the pre-construction and postconstruction sample periods. Using our cross-section data we calculated an area, perimeter, entrenchment ratio, bank height ratio and perimeter to area ratios for each cross section. Pair-wise testing was performed on treatment and control cross-sections. Control cross-sections were all surveys conducted in the upper and reference sub-reaches. Treatment cross-sectional surveys were conducted in the lower sub-reach. Additionally, we performed a $2 \times 3$ factorial analysis of variance (ANOVA) with reach and year being our independent variables and entrenchment ratio, bank height ratio, area, perimeter, perimeter: area ratio, and coefficient of variation as our response variables to test for differences between pre- and post-construction. Post hoc analysis was performed with Tukey HSD tests to determine which combinations of means were significantly different.

We used paired t-tests on retention data to test for differences in retentiveness between the pre-construction and post-construction sample periods. Due to the nature of the structures and the downstream facilitation of water we expect retention to decrease in the lower reach in 2010. 
For analysis of benthic macroinvertebrates, we use a modified West Virginia Stream Condition Index (mWVSCI) (Merriam et al. 2011). The original WVSCI uses a subsample of 200 individuals and many parameters to calculate a final score (Gerritsen et al. 2000). The WVSCl uses the following metrics, \%EPT, \% dominant individuals, \% mayflies, \%stoneflies, EPT abundance, and EPT family richness. The final result of the WVSCI is an index number that ranges from 0-100 (Gerritsen et al. 2000). The $\mathrm{mWVSCI}$ differs from the WVSCI in that all individuals, not a subsample, are used in the $m \mathrm{WVSCl}$ final calculation. The index score results in a condition of excellent, good, marginal, and poor. These categories correspond to WVSCI scores of $>85.0,85.0-70.0,69.9-55.0$, and $<55.0$, respectively. We used a $3 \times 2 \times 2$ factorial ANOVA with our factors being reach, season, and substrate and our response variables being; \%EPT, $m \mathrm{WVSCl}$ score, and abundance to test the null hypothesis that cobble and sand substrate yield the same macroinvertebrate community.

Reach types were compared based on their overall fish community structure using analysis of similarity (ANOSIM) on Bray-Curtis distance coefficients (Merovich and Petty 2010). ANOSIM is a non-parametric test of significance between two or more groups based on a measure of distance between individual sites (Van Sickle and Hughes 2000). ANOSIM measures classification strength (CS) by subtracting the mean between-group similarity from the mean within-group similarity. Permutation tests $(10,000)$ were used to 
test the null hypothesis that the lower reach fish community remained constant from 2009 to 2010 (Van Sickle 1997). Fish ANOSIM's are displayed in a Nonmetric Multiple Dimensional Scaling (NMDS) ordination. NMDS ordinates sites based on similarities of fish community. In addition to ANSOSIM we used ANOVA to further investigate the Little Coal River fish assemblage. We used a $2 \times 3$ factorial ANOVA with our factors being reach and year and our response variables being; number of game fish, number of non-game fish, fish abundance, and fish diversity. Lastly, Shannon-Weiner Index was calculated for fish diversity.

We expected a difference in physical parameters and biological communities from 2009 and 2010 in the lower reach. Additionally, we expected the morphology and community of the upper and reference reaches to remain constant from 2009-2010. Presumably, we would expect the lower 2010 reach to resemble the upper or reference reaches in community, morphology, and habitat availability.

\section{Results}

\section{Water Chemistry}

Laboratory results of our water samples showed excess levels of total dissolved solids (TDS), conductivity, and sulfates (Table 1). Although all tested metals were within the United States Environmental Protection Agency (USEPA) standards, however the Little Coal River far exceeds an impaired conductivity. 
Conductivity is a direct correlation between TDS and sulfates and is a major constraint on aquatic ecosystems (Kimmel and Argent 2010; Weber-Scannell and Duffey 2007)

\section{$\underline{\text { Thalweg Profile }}$}

Mean water depth remained constant from 2009 to 2010 over the entire study reach (Table 2 and Figure 4). In 2009 the depth ranged from $0.18 \mathrm{~m}$ to $2.02 \mathrm{~m}$ (Figure 5) and in 2010 depth ranged from $0.14 \mathrm{~m}$ to $2.12 \mathrm{~m}$ (Figure 6). Mean depth decreased slightly in the upper reach and reference reach, however increased from $0.75 \mathrm{~m}$ in 2009 to $0.92 \mathrm{~m}$ in 2010 in the lower reach. Coefficient

of variation of depth increased over the entire river from 0.48 to $0.58: 0.46$ to 0.48 in the lower reach; however greatly decreased in the upper reach from 0.92 to 0.52 , and remained constant in the reference reach. Distance to fish cover decreased by $\sim 50 \%$ in the lower reach, increased by $\sim 20 \%$ in the reference reach, and remained constant in the upper reach in 2010 (Table 2). Distance to fish cover increased in the reference reach due to beaver activity. In 2009 distance to fish cover ranged from $1 \mathrm{~m}$ to $50 \mathrm{~m}$ (Figure 7) and from $1 \mathrm{~m}$ to $47 \mathrm{~m}$ in 2010 (Figure 8). A change in distance to fish cover map was created to see the specific areas that had the greatest change (Figure 9). Decreases in depth in the upper reach had no effect on distance to fish cover. However, increases in depth and distance to fish cover were associated with the new construction of structures in the lower reach. 


\section{$\underline{\text { Substrate }}$}

Lower reach structures cause a $+15 \%$ shift in substrate towards cobble/gravel between 2009 and 2010 (Table 3; Figure 10). However, sand in the upper sub-reach substrate changed by $+7 \%$ (Table 3, Figure 10). The entire study area increased in sand substrate by $3 \%$ where the reference sub-reach only changed within gravel, cobble, and boulder substrate (Table 3; Figure 10). The finer scale substrate composition maps in the upper, reference, and lower sub-reaches (Figures 11-15); and of the entire study reach (Figures 16-20) show the change in substrate composition from 2009 to 2010 . Although we detected a measurable difference in substrate between 2009 and 2010 Fisher's exact test results indicate no significant changes in substrate composition (Table 4).

\section{$\underline{\text { Longitudinal profiles }}$}

The longitudinal profiles show the change in stream bed morphology, water depth, and bankfull height. Average pool depth, average distance to pool, number of pools, and average pool length with respect to year and sub-reach were also derived from the longitudinal profiles (Table 5). The number of pools increased in the lower sub-reach from 2 to 5 and the average distance to pools decreased from $373 \mathrm{~m}$ to $159 \mathrm{~m}$. However pools did get shorter in the lower subreach by $\sim 18 \mathrm{~m}$. The upper and reference reaches remained constant in pool attributes between 2009 and 2010. Longitudinal profiles are displayed as scatter plots (Figures 21-23). 


\section{Cross-sectional Geometry}

Pairwise comparisons show treatment cross sectional surveys (i.e., crosssectional surveys associated with new structures in the lower reach) had a significant change in entrenchment ratio $(P>0.001)$, however there were no significant changes in control cross sections from 2009 to 2010 (Table 6). Results of $3 \times 2$ factorial ANOVA revealed reach effects on channel area, perimeter, perimeter:area ratio, coefficient of variation in depth, bank height ratio and entrenchment ratio (Table 7). Also a year effect was detected for coefficient of variation in depth. Tukey's post hoc test results show only the significant interactions of each variable with respect to reach and year (Table 8 ). We found a statistical difference in entrenchment ratio, which was due to the formation of scour pools below HES's. The cross section results revealed no change in area or perimeter, which leads us to believe that bank stability, was consistent between 2009 and 2010.

\section{Organic Matter Retention}

We found no statistical difference in organic matter retention between 2009 and 2010 in the upper, reference, and lower reaches $(p=0.37, p=0.28$, and $p=0.47$ respectively). The upper and reference sub-reaches remained relatively consistent from 2009 to 2010 (Figures 24); however the lower sub-reach retained 18 fewer dowel rods in 2009 than in 2010 (Table 9). There was clearly an 
obstruction in the lower reach at $\sim 200 \mathrm{~m}$ in 2009 that lead to the majority of the dowel rods being retained that was not present in 2010 (Figure 24).

\section{Macroinvertebrate Assemblage}

Our analysis of macroinvertebrate data revealed a significant effect of substrate type $(p=0.0001)$ and season $(p=0.0001)$, on $m W V S C l$, total abundance and \%EPT (Table 10). Additionally, macroinvertebrate abundance and \%EPT responded to a substrate $x$ season interactive effect (Table 10). Tukey's post hoc test revealed this interaction was driven by all but one of the combinations (Table 11). Macroinvertebrate MeanSim is displayed as a NMDS in the first and second dimension with a stress value of 13.6 with macroinvertebrate community vectors fitted to the plot (Figure 25). NMDS shows a clear separation between cobble/gravel and sand/silt samples with $m \mathrm{WVSCl}, \% \mathrm{EPT}$, and abundance strongly correlating with cobble/gravel samples (Figure 25).

The abundance of macroinvertebrates in cobble/gravel substrate was significantly greater than in sand/silt substrate (Figure 26 ). Less than $4 \%$ of macroinvertebrates were collected from sand/silt substrate each year. With our macroinvertebrate abundance and our substrate type we calculated habitat weighted abundance scores for macroinvertebrates (Figure 28). Habitat weighted abundance increased $20 \%$ in 2010 from 2009 due to the localized change in substrate type associated with structure construction (Figure 28). 


\section{Fish Assemblage}

A total of 35 fish species were collected in both the 2009 and 2010 sampling seasons (Table 12). ANOSIM results indicate a significant dissimilarity $(P=0.035)$ in fish community structure between 2009 and 2010 (Table 13). Pairwise comparisons showed that the lower reach in 2010 was significantly dissimilar to the upper and reference reaches in 2009. Additionally, the lower reach in 2009 was significantly dissimilar to the upper and lower reaches in 2010. All other pairwise comparisons indicated similar communities. A mean similarity dendrogram shows that the replicates in the lower and reference reach in 2010 were, on average more similar to the other groups rather than themselves (Figure 28) and the overall average dissimilarity was high with a Bray-Curtis value of 0.84 . We projected our MeanSIM results as a Nonmetric Multiple Dimensional Scaling (NMDS) ordination and displayed is the first and second dimension with a stress value of 14.605 (Figure 29). Although no significant pattern emerged, a separation of post-construction sites can be seen (Figure 29).

We observed a significant $(p=0.019)$ decline in game fish abundance in 2010 in the upper and lower reaches (i.e., in reaches with structures present). In contrast, there was a significant increase in game fish abundance within the reference reach (Figure 30). Although in the upper section in 2010 there was far less non-game fish captured, the reference reach increased in non-game fish abundance, and the lower reach remained constant (Figure 31). Total fish abundance declined significantly in the upper reach in 2010, significantly 
increased in the reference reach, and declined slightly in the lower reach (Figure 32). Shannon-Weiner Index shows that fish diversity remained constant among reaches and between years (Figure 33). Catch per unit effort $(\# / m)$ decreased in the upper reach by $\sim 50 \%$, however remained constant in the other reaches (Figure 34). A $2 \times 3$ factorial ANOVA showed that total diversity responded to a reach effect and game fish abundance responded to a year effect (Table 14). Tukey's post hoc tests revealed no significant interactions.

\section{Discussion}

There is urgent need for river restoration due to anthropogenic impacts, such as coal mining. Consequently, stream and watershed restoration projects are becoming increasingly prevalent in North America (Bash and Ryan 2002, Bernhardt et al. 2005, Palmer et al. 2005). With the increase in restoration activity, skepticism and criticism about the success of such projects has also increased. For example, Lake et al. (2007) argued that stream restoration rarely accounts for ecological theory and ecosystem processes. Also, some scientists believe that stream restoration can only be successful if implemented at the watershed scale, but yet most restoration projects are implemented at scales of 1-2 km (Roper et al. 1997). Additionally, others believe that most aquatic ecosystems cannot be restored through stream channel modification alone (Beschta et al.1994, Thompson and Stull 2002, Pretty et al. 2003). Moerke et al. (2004) argue that restoration on the reach scale may be ineffective in the face of degradation that typically occurs at the scale of an entire watershed. 
Clearly, more research is needed to determine which types of restoration activities are effective and which types are not. In our current study, we evaluated the effectiveness of habitat enhancing structures (HES) constructed in a medium to large sized river in the central Appalachians. Our objectives were to identify the strengths and weaknesses of this restoration method, compare the ecological benefits of HES construction on large rivers to headwater stream losses that occur as a result of large scale surface mining, and to make recommendations for the future.

Several of the physical and biological parameters that we measured demonstrated a positive ecological response to HES construction on the Little Coal River mainstem. Although in many cases statistical tests were not significant, there was a measurable positive change in physical variables such as water depth, distance to fish cover, cobble/gravel substrate composition, number of pools, depth of pools, and entrenchment ratio. Benthic macroinvertebrates exhibited a positive response to HES construction that was mediated by changes in substrate composition; invertebrate densities and community metrics were highest in cobble/gravel substrates. Consequently, benthic macroinvertebrate variables improved following HES construction due to localized shifts in substrate composition from sand to gravel. 
Our results demonstrating positive effects of HES construction on river habitat structure is consistent with several previous studies (Chin et al. 2009, Chin et al. 2010, and van Zyll De Jong et al. 1997). The water became deeper at the structure location due to the large scour pools created below. This is consistent with a comprehensive study performed by Whiteway et al. (2010). Through a literature search of restoration projects, they found that all of the 51 reports investigated had a positive change on pool size and depth due to mitigation (Whiteway et al. 2010). Coefficient of variation (CV) in depth increased over the entire study reach and the lower reach, which demonstrates that the river bed became more complex. The upper reach decreased in CV due to filling in of the upper reach structures with sand. Levell and Chang (2008) found similar results that pools were created and remained at equilibrium in a restored reach of river. However, they also observed that the mean particle size in the restored reach decreased and may lead to aggradation (Levell and Chang 2008). Additionally, Champoux et al. (2003) found that a restoration project in the 1960's increased in pool area from $267 \mathrm{~m}^{2}$ to $625 \mathrm{~m}^{2}$ after restoration, but has since decreased to $488 \mathrm{~m}^{2}$. Therefore, it is unclear if our results will persist over time.

We found that the amount of fish cover in the Little Coal River was increased by boulder placement, vane arm construction, and pool creation in the lower reach in 2010. Because of our study design, which compared pre- and post-construction conditions, improvements in fish habitat quality in the lower 
reach are likely due to HES construction. Pool availability has been directly correlated with abundance and biodiversity of macroinvertebrates and fish (Edwards et al. 1984). Furthermore, Warren et al. (2010) found that pool availability and persistence was correlated with fish abundance in the headwaters of New York and Vermont, USA. They also found that species richness was higher in permanent pools and that pool preservation is just as important as pool creation (Warren et al. 2010). In contrast, Lepori et al. (2005) found that increased structural heterogeneity and pool creation had little effect on fish biodiversity on a Swedish tributary. Lepori et al. (2005) argued that fish species response to local restoration efforts was constrained due to the prevalence of degraded conditions that remained within the watershed as a whole.

Although we did not detect a significant change in substrate composition at the reach scale as a result of HES construction, we did detect a consistent change from sand-silt dominated substrata to cobble-gravel substrata within close proximity of structures. However, in the upper sub-reach where HES construction was completed prior to the start of our study, we found that sand substrate increased from 2009-2010. The same practitioner was used to construct all the structures in the Little Coal River. Through personal correspondence I learned they had never taking on a project of this size and the upper reach structures were experimental in deflection angle and structure height. Before constructing the lower reach structures the practitioners examined, 
through my 2009 data, which structures has the broadest impacts, and replicated those structures in the lower reach. Moreover, stream mitigation is a relatively new science and monitoring has only occurred in the past few decades, the "life expectancy" of HESs is largely unknown (Palmer et al. 2007 and Thompson 2006). It is possible that the function of structures in the Little Coal River may diminish or improve over time.

Similar to our results in the upper reach, Habersack and Nachtnebel (1995) found that just a year after restoration had been implemented fine substrate had deposited in the main channel $\sim 16 \mathrm{~cm}$ deep in the Drau River of south-central Europe. Additionally, Shields et al. (2003) found progressive failure of large woody debris structures in a Northwest Mississippi stream. They noted a $30 \%$ structure failure resulting in bank erosion and sediment deposition. In contrast, Moerke et al. (2004) found that 5 years after a restoration project on a $3^{\text {rd }}$ order Indiana stream, fine sediments remained low relative to an unrestored reach. Continued monitoring of the Little Coal River structures will be required to determine if the positive effects of HES construction on sediment composition persists over time.

Macroinvertebrate assemblages were strongly influenced by substrate composition in the Little Coal River. Macroinvertebrate abundance and diversity was an order of magnitude lower in sand-silt substrates than in cobble-gravel substrates. Substrate-dependent variation in benthic macroinvertebrates is a 
common feature of streams across a wide range of conditions, including small, high gradient streams (Petty and Grossman 2004, Thompson et al. 2001) and larger, low gradient rivers (Benke et al. 1980, Chakona et al. 2008, and Beauger et al. 2006).

Given that HESs resulted in a decrease in the prevalence of sand-silt and an increase in the prevalence of cobble-gravel, then localized increases in macroinvertebrate abundance and diversity can be attributed to HES construction. This result is consistent with several other studies that observed improvements in macroinvertebrate assemblages after restoration (Gortz 1998, Muotka et al. 2002, Miller et al. 2010, and Jungwirth et al. 1993). However, Laasonen et al. (1998) found that macroinvertebrate abundances in a Finnish stream with in-stream structures were comparable to those in unmitigated reference channelized streams. Similarly, Harrison et al. (2004) found that instream structures had no effect on benthic macroinvertebrates, but they attribute these results to larger scale factors constraining benefits of stream habitat rehabilitation.

Our conclusions on the effectiveness of HES construction in improving benthic macroinvertebrate assemblages in the Little Coal River are as follows. First, HES construction can produce measureable, immediate changes in substrate composition within close proximity of the structures. Second, benthic macroinvertebrate assemblages improve as a result of HES construction due to 
strong substrate-dependent distribution patterns (i.e., HESs result in increased cobble-gravel substrata, which is preferred habitat for benthic assemblages). Third, the spatial extent of macroinvertebrate response is constrained, because HES construction only affects substrates within close proximity of the structures. Fourth, it is unclear how long the positive effects of HESs on substrate composition persist, and therefore, the persistence of positive benefits on benthic invertebrate assemblages is unclear. Fifth, the overall benefits of HES construction on benthic macroinvertebrates are likely constrained due to elevated TDS concentration and conductivity within the Little Coal River (Pond et al. 2010, Merriam et al. 2011).

Fish assemblage response to HES construction was measurable, but complex. We observed a significant shift in the lower reach fish assemblage from pre-construction to post-construction. Specifically we observed a notable increase in the shiner and chub community. Approximately $63 \%$ of the fish captured in 2010 were shiners and chubs opposed to $40 \%$ in 2009. Additionally, we saw a decrease in game fish from $\sim 33 \%$ to $20 \%$ in 2010 . This is consistent with Detenbeck et al. (1992) who found that centrarchids and cyprinids were the most resilient to a disturbance and often the first to recolonize an area.

Despite a general shift in fish assemblage structure, we did not observe a significant effect of HES construction on fish abundance or diversity. Although fish abundance and diversity has been shown to increase with the use of artificial 
cover (Feger 2010, Lehtinen et al. 1997, Madejczyk 1998), Sweka et al. (2010) found after 6 years that large woody debris additions had no positive effects on brook trout populations in headwater streams. Additionally, Lepori (2005) found limited recovery of fish after stream restoration. Gravel/cobble substrate is superior to sand substrate for fish habitat (Barlaup et al. 2008, McManamay et al. 2010, and Salas and Synder 2010). HES's are exposing more cobble/gravel, but we have yet to see a localized increase in fish abundance due to HES's. Lund (1976) and Edwards et al. (1984) found that it takes 1-5 years for fish populations to recover from mitigation processes such as boulder placement, pool construction, and artificial riffle construction. Continued monitoring in the Little Coal River will be needed to determine if fish assemblages respond to HES construction over time.

Recreational fishing pressure could be limiting our fish detection at HES's (Paxton and Stevenson1979, Wilber 1978). Increased fishing pressure in restored reaches has been considered the cause of poor study outcomes in other systems (Hunt 1988 and Avery 2004). The Little Coal River project was publicized numerous times in the local media (Dennis Stottlemyer, WVDEP, personal communication). The public was aware of the changes occurring on the river and the recreational opportunities that may accompany these structures. Little Coal River Road parallels the river for $\sim 5 \mathrm{~km}$ and provides easy access to many of the new structures. Numerous studies have shown decreases in fish population due to angling (Blackford 2009, Hesse 1994, and Murawski 2010), 
and this fishing pressure may have offset gains in fish populations from structure placement. In fact, the declines in game fish abundance in the upper reach from 2009-2010 and low game fish abundance associated with the structures relative to the reference reach provide support for this hypothesis in the Little Coal River.

In addition, fish abundances may not be recovering in the immediate area of restoration due to a broader impairment of fish assemblages in this region (Freund and Petty 2007). The Little Coal River is just one segment within a region that is heavily impacted due to mining and other development activities (Merriam et al. 2011). Several studies have shown that a fish community recovery is dependent on the interconnectivity of drainage networks (McClurg et al. 2007, Petty et al. 2005). Consequently, extensive fish community loss within a watershed due to poor habitat and water quality may limit the ability of HES's to fully recover fish populations in localized stream reaches.

We detected no measureable positive change in water chemistry as a result of HES construction. These structures were not designed to address water quality, and therefore these results were expected. Although the structures manage the issue of poor habitat quality, it is paramount that elevated TDS in the Little Coal River be addressed. Studies have shown that regional conditions strongly influence local systems that would otherwise be productive (Freud and Petty 2007, Martin 2004). Ultimately, water quality has to be addressed for the Little Coal River to return to its historic conditions. 
In addition to water quality issues constraining the river we found that organic matter retention declined as a result of HES construction. The structures were designed to facilitate downstream transport of sediments, not retain organic matter. However, a major function of the headwater streams lost due to MTR/VF mining is organic matter retention. Muotka and Laasonen (2002) found that a stream in Finland with in-stream structures had higher retention than its unmitigated counterpart. However, Rosi-Marshall et al. (2006) found that structures in a $3^{\text {rd }}$ order stream in Northern Michigan had no effect on retention and it remained as retentive as the control reaches. The inability of the Little Coal River HESs to perform all of the lost functions supplied by headwater streams suggests that what constitutes mitigation depends on project goals, because restored stream miles may not compensate for lost functions.

The $\mathrm{BACl}$ design has been embraced in fields of ecology, but there is a clear void in aquatic restoration, especially larger rivers (Stewart et al. 2009). Bernhardt et al. (2007) found in a comprehensive survey that $25 \%$ of stream restoration practitioners applied a $\mathrm{BACl}$ design to their monitoring, however it should be noted that this information comes from the practitioners' monitoring plans and not those of researchers. Additionally, Palmer et al. (2009) synthesized stream restoration projects that studied the effects of restoration on habitat heterogeneity and invertebrates. They searched from 1975-2008 and discovered 78 independent studies that met their criteria (Palmer et al. 2009). 
Only 6 of the 78 studies performed pre- and post-construction data collection (Palmer et al. 2009). Lake et al. (2007) argue that determining project success requires pre-restoration data. However, because many studies lack prerestoration data, information from river restoration research is often ambiguous.

Most researchers study stream restoration projects after the construction of the structure with little or no pre-construction data; thus determination of success is compromised (Bernhardt et al. 2007). For example, Stewart et al. (2009) performed a review of salmonid in-stream habitat enhancing structures. They found that less than half of the 179 articles implemented a BACI design. They further explain that the lack of BACI designed studies was the limiting factor in their analysis and yielded equivocal results (Stewart et al. 2009). The demand for stream restoration is apparent worldwide; however, without proper monitoring and study design the science of stream restoration will never evolve and meet its full potential. Stream restoration ecology and other similar fields will greatly benefit from experimental designs, such as the present study, that utilize preimpact information.

Palmer et al. (2005) provided five criteria for restoration success. We have met 4 of those criteria and one has yet to be determined. The design of the project was based on a specific guided image of a more dynamic and productive system that can exist at this site over time. We did measure an improvement of the rivers ecological condition. After construction, river entry areas were 
reseeded and trees were planted to restore the riparian zone to pre-construction conditions. Also, with our BACl study design both pre- and post-construction data was collected and made publically available. The criteria concerning the system being more self-sustaining and resilient to external perturbations that only minimal follow-up is required has yet to be determined due to the young age of the structures and only 2 years of data collection.

We found measureable, but constrained, functional improvements in the Little Coal River as a result of HES construction. Palmer et al. (2007) argues that due to the variability of aquatic ecosystems, a measurable increase from restoration may be a signal of successful restoration. Since monitoring stream restoration has only occurred in the past few decades, there is much debate over the success or failure of a project and the duration of post-construction monitoring (Thompson 2006). Also, Muotka et al. (2002) found some streams had 8 year biological recovery periods. In contrast, Tikkanen et al. (1994) found biological recovery was shown as quickly as 10 days. Due to the variability of aquatic ecosystems, monitoring on the Little Coal River will have to continue to determine the overall success of this project. 


\section{Literature cited}

Al-Chokhachy, R., B.B. Roper, and E.K. Archer. 2010. Evaluating the status and trends of physical stream habitat in headwater streams within the interior Columbia River and upper Missouri River basins using an index approach. Transactions of the American Fisheries Society. 139(4): 1041-1059.

Avery, E.L. 2004. A compendium of 58 trout stream habitat development evaluations in Wisconsin - 1985-2000. Wisconsin Department of Natural Resources Research Report No. 187, Bureau of Integrated Science Services, Waupaca, Wisconsin.

Barlaup, B.T., S.V. Gabrielsen, H. Skoglund, and T. Wiers. 2008. Addition of spawning gravel-a means to restore spawning habitat of Atlantic salmon (Salmo salar L.) and anadromous and resident brown trout (Salmo trutta L.) in regulated rivers. River Research and Applications 24: 543-550.

Barmuta, L. 2002. Monitoring, survey and experimentation in streams and rivers.Cambridge University Press, Cambridge, UK.

Baron, J.S., N.L Poff, P.L. Angermeier, C.N. Dahm, P.H. Gleick, N.G. Hairston, R.B. Jackson, C.A. Johnston, B.D. Richter, and A.D. Steinman.2002. Meeting ecological and societal needs for freshwater. Ecological Applications 12:12471260. 
Bash, J.S. and C.M. Ryan. 2002. Stream restoration and enhancement projects: is anyone monitoring? Environmental Management 26:877-885.

Beauger, A., N. Lair, R. Reyes-Marchant, and J.L. Peiry. 2006. The distribution of macroinvertebrate assemblages in a reach of the river Allier (France), in relation to riverbed characteristics. Hydrobiologia 571: 63-76.

Beechie, T.J., G. Pess, P. Roni, and G. Giannico. 2008. Setting river restoration priorities: A review of approaches and a general protocol for identifying and prioritizing actions. North American Journal of Fisheries Management 28: 891-905.

Benke, A. C., and J. B. Wallace. 1980. Trophic basis of production among netspinning caddisflies in a southern Appalachian stream. Ecology 61:108-118.

Bernhardt, E.S., M.A Palmer, and J.D. Allan et al. 2005. Synthesizing U.S. river restoration efforts. Science 205: 636-637.

Bernhardt, E.S., E.B. Sudduth, M.A. Palmer, J.D. Allan, J.L. Meyer, and G. Alexander. 2007. Restoring rivers one reach at a time: results from a survey of U.S. river protection practitioners. Restoration Ecology 15: 482-494. 
Beschta, R.L.,W.S. Platts,J.B. Kauffman, and M.T. Hill. 1994. Artificial stream restoration—money well spent or an expensive failure? In: Environmental restoration: UCOWR 1994 Annual Meeting. Big Sky, Montana,76-104.

Blackford, M. 2009. Fishers, Fishing, and Overfishing: American Experiences in Global Perspective, 1976-2006. Business History Review 82(3).

Bodkin, R., J. Kern, P. McClellan, A. Butt, and C. Martion. 2007.Limiting total dissolved solids to protect aquatic life. Journal of Soil and Water Conservation 62(3): 57A-61A.

Brinson, M.M. and R. Rheinhardt. 1996. The role of reference wetlands in functional assessment and mitigation. Ecological Applications 6: 69-76.

Bryant, M.D.,J.P. Caouette, and B.E. Wright. 2004. Evaluating stream habitat survey data and statistical power using an example from southeast Alaska. North American Journal of Fisheries Management. 24: 1353- 1362.

Bunn, S. E., and P. M. Davies. 2000. Biological processes in running waters and their implications for the assessment of ecological integrity. Hydrobiologia 422423(0):61-70 . 
Burns, S. 2005. Dissertation. Bringing Down the Mountains: The Impact of Mountaintop Removal Surface Coal Mining on Southern West Virginia Communities, 1970-2004. West Virginia University.

Champoux, O., P.M. Biron, and A.G. Roy. 2003. The Long-Term Effectiveness of Fish Habitat Restoration Practices: Lawrence Creek, Wisconsin. Annals of the Association of American Geographers 93: 42-54.

Chin A., S. Anderson, A. Collison, B.J. Ellis-Sugai, J.P. Haltiner, J.B. Hogervorst, G.M. Kondolf, L.S. O'Hirok, A.H. Purcell, A. Riley, and E.E. Wohl. 2009. Linking theory and practice for restoration of step-pool streams. Environmental Management 43: 645-661.

Chin A., F. Gelwick, D. Laurencio, L.R. Laurencio, M.S. Byars, and M. Scoggins. 2010. Linking Geomorphological and Ecological Responses in Restored Urban Pool-Riffle Streams. Ecological Restoration 28(4):460-474.

Conway, J.C., C.P. Nadeau, and L. Piest. 2010. Fire helps restore natural disturbance regime to benefit rare and endangered marsh birds endemic to the Colorado River. Ecological Applications 20(7): 2024-2035. 
Chakona A., C. Phiri, C.H.D. Magadza, and L. Brendonck. 2008. The influence of habitat structure and flow permanence on macroinvertebrate assemblages in temporary rivers in north-western Zimbabwe. Hydrobiologia 607:199-209.

Detenbeck, N.E., P.W. DeVore, G.J. Niemi, and A. Lima. 1992. Recovery of temperate-stream fish communities from disturbance: a review of case studies and synthesis of theory. Environmental Management 16: 33-53.

Edwards, C.J., B. L. Griswold, R. A. Tubb, E. C. Weber, and L.C. Woods. 1984. Mitigating effects of artificial riffles and pools on the fauna of a channelized warmwater stream. North American Journal of Fisheries Management 4:194-203.

Entrekin, S.A., T.J. Hoellein, G.A. Lamberti, J.L. Tank, and E.J. RosiMarshall.2008. Responses in organic matter accumulation and processing to an experimental wood addition in three headwater streams. Freshwater Biology $53: 1642-1657$.

Feger, B. T. and T.W. Spier. 2010. Evaluation of artificial PVC pipe structures as fish habitat in Spring Lake, Western Illinois, USA. Lakes \& Reservoirs: Research \& Management 15:335-340. 
Freund, J. G. and J. T. Petty. 2007. Response of fish and macroinvertebrate bioassessment indices to water chemistry in a mined Appalachian watershed. Environmental Management 39:707-720.

Fritz, K. M., S. Fulton, B. R. Johnson, C. C. Barton, J. D. Jack, D. A. Word, and R. A. Burke. 2010. Structural and functional characteristics of natural and constructed channels draining a reclaimed mountaintop removal and valley fill coal mine. Journal of the North American Benthological Society 29:673-689.

Giller, P. S. 2005. River restoration: seeking ecological standards. Editor's introduction. Journal of Applied Ecology 42(2):201-207.

Gomi, T.,R.C. Sidle, and J.S. Richardson. 2002. Understanding processes and downstream linkages of headwater systems.BioScience, 52 905-916.

Gørtz, P.1998. Effects of stream restoration on the macroinvertebrate community in the River Esrom, Denmark. Aquatic Conservation: Marine and Freshwater Ecosystems 8:115-130.

Habersack, H. and H.P. Nachtnebel. 1995. Short-term effects of local river restoration on morphology, flow field, substrate and biota. Regulated Rivers: Research \& Management 10:291-301. 
Harrison S.S.C., J.L. Pretty, D. Shepherd, A.G. Hildrew, C. Smith, and R.D. Hey. 2004. The effect of instream rehabilitation structures on macroinvertebrates in lowland rivers. The Journal of Applied Ecology, 41, 1140-1154.

Hartman, K.J., J.D. Kaller, J.W. Howell, and J.A. Sweka. 2005. How much do valley fills influence headwaters streams? Hydrobiologia 532:91-109.

Hesse, L. W. 1994. The status of Nebraska fishes in the Missouri River, 4. Flathead catfish Pylodictis olivaris, and blue catfish, Ictalurus furcatus (Ictaluridae). Proceedings of the Nebraska Academy of Sciences 21:89-98.

Hildebrand, R. H., A. C. Watts, and A. M. Randle. 2005. The myths of restoration ecology. Ecology and Society 10(1):19.

Hodel,M.B. "West Virginia Report Focuses on Environment," The Washington Post, April 22, 2004.

Hunt, R.L. 1988. Compendium of 45 trout stream habitat development evaluations in Wisconsin during 1953-1985. Technical Bulletin No. 126, Wisconsin Department of Natural Resources, Madison, Wisconsin. 
Jansson, R., H. Backx, A.J. Boulton, M. Dixon, D. Dudgeon, F. Hughes, K. Nakamura, E. Stanley, and K. Tockner. 2005. Stating mechanisms and refining criteria for ecologically successful river restoration: a comment on Palmer et al. (2005). Journal of Applied Ecology 42:218-222.

Jungwirth, M., O. Moog, and S. Muhar. 1993. Effects of river bed restructuring on fish and benthos of a fifth order stream, melk, Austria. Regulated Rivers: Research \& Management 8:195-204.

Karr, J. R. 1999. Defining and measuring river health. Freshwater Biology $41: 221-234$

Kentucky Department for Environmental Protection, Division of Water, Water Quality Branch.A Macroinvertebrate Bioassessment Index for Headwater Streams of the Eastern Coalfield Region, KY.Frankfort, KY: Kentucky Department for Environmental Protection, 2002

Kimmel, W. G. and D.G. Argent. 2010. Stream fish community responses to a gradient of specific conductance. Water, Air, and Soil Pollution 206:49-56.

Lake, P. S., N. Bond, and P. Reich. 2007. Linking ecological theory with stream restoration. Freshwater Biology 52(4):597-615. 
Laasonen, P., T. Muotka and I. Kivijärvi. 1998. Recovery of macroinvertebrate communities from stream habitat restoration. Aquatic Conservation: Marine and Freshwater Ecosystems 8:101-113.

Lehtinen, R.M., N.D. Mundahl, and J.C. Madejczyk. 1997. Autumn use of woody snags by fishes in backwater and channel border habitats of a large river. Environmental Biology of Fishes 49:7-19.

Lepori, F., D. Palm, E. Brannas, and B. Malmqvist. 2005. Does restoration of structural heterogeneity in streams enhance fish and macroinvertebrate diversity? Ecological Applications 15: 2060-2071.

Levell, A.P. and H. Chang. 2008. Monitoring the channel process of a stream restoration project in an urbanizing watershed: a case study of Kelley Creek, Oregon, USA. River Research and Applications 24:169-182.

Lund, J.A. 1976. Evaluation of channelization and mitigation on the fishery resources of the St. Regis River, Montana.Fish and Wildlife Service, USDI.FWS/OBS-76/06.Washington, D.C.

Madejczyk, J.C., N.D. Mundahl, and R. M. Lehtinen.1998. Fish assemblages of natural and artificial habitats within the channel border of the upper Mississippi River. American Midland Naturalist 139: 296-310. 
Malcom, J.W. and W.R. Radke. 2008. Effects or riparian and wetland restoration on an avian community in Southeast Arizona, USA. The Open Conservation Biology Journal 30-36.

Martin, R.W. 2004. Watershed-scale thermal regimes and the distribution of brook trout (Salvelinus fontinalis) and smallmouth bass (Micropterus dolomieui) in the Cheat River watershed, WV. Master's Thesis, West Virginia University College of Agriculture, Forestry, and Consumer Sciences.

McClurg, S. E., J. T. Petty, P. M. Mazik, and J. L. Clayton. 2007. Stream ecosystem response to limestone treatment in acid impacted watersheds of the Allegheny Plateau. Ecological Applications 17(4):1087-1104.

McManamay,R.A., D. J. Orth, C.A. Dolloffand,and M. A. Cantrell. 2010. Gravel addition as a Habitat Restoration Technique for Tailwaters. North American Journal of Fisheries Management 30(5):1238-1257.

Mecklenburg, D., and A. Ward. 2004. STREAM modules: Spreadsheet tools for river evaluation, assessment, and monitoring. In Proc. ASAE Specialty Conference Self-Sustaining Solutions For Streams, Watersheds, and Wetlands, 312-322. St. Joseph, Mich.: ASAE. 
Merovich, G.T. and J.T. Petty. 2010. Continuous response of benthic macroinvertebrate assemblages to a discrete disturbance gradient: consequences for diagnosing stressors. Journal of the North American Benthological Society 29(4):1241-1257.

Merovich, G. T. and J. T. Petty. 2007. Interactive effects of multiple stressors and restoration priorities in a mined Appalachian watershed. Hydrobiologia 575:1331.

Merovich, G. T., J. M. Stiles, J. T. Petty, P. F. Ziemkiewicz, and J. B. Fulton. 2007. Water chemistry-based classification of streams and implications for restoring mined Appalachian watersheds. Environmental Toxicology and Chemistry 26(7):1361-1369.

Merriam, E.R., J.T. Petty,G.T. Merovich, J.B. Fulton, and M.P. Strager.2011. Additive effects of mining and residential development on stream conditions in central Appalachian watershed. Journal of the North American Benthological Society 30(2)399-418.

Merritt, R. W., and K. W. Cummins. 2008. An introduction to the aquatic insects of North America, Fourth edition. Kendall/Hunt Publishing Co., Dubuque, IA. 
Meyer, J.L., D.L. Strayer, J.B. Wallace, S.L. Eggert, G.S. Helfman, and N.E. Leonard. 2007. The Contribution of Headwater Streams to Biodiversity in River Networks. Journal of the American Water Resources Association 43:86-103.

Meyer, J.L. \& Wallace, J.B. 2001. Lost linkages and lotic ecology: rediscovering small streams. Ecology: Achievement and Challenge 295-317.

Miller, S. W., P. Budy, and J.C. Schmidt. 2010. Quantifying Macroinvertebrate Responses to In-Stream Habitat Restoration: Applications of Meta-Analysis to River Restoration. Restoration Ecology 18:8-19.

Minter, M. 2009. Thesis. Organic matter processing and opportunities for stream mitigation in an intensively mined West Virginia watershed. West Virginia University.

Moerke A.H., K.J. Gerard, J.A. Latimore, R.A. Hellenthal and G.A. Lamberti. 2004. Restoration of an Indiana, USA, stream: bridging the gap between basic and applied lotic ecology. Journal of the North American Benthological Society 23(3):647-660.

Murawski, S.A. 2010. Rebuilding depleted fish stocks: the good, the bad, and, mostly, the ugly. ICES Journal of Marine Science 67: 1830-1840. 
Muotka, T. and P. Laasonen. 2002. Ecosystem recovery in restored headwater streams: the role of enhanced leaf retention. Journal of Applied Ecology, 39:145156.

Muotka, T., R. Paavola, A. Haapala, M. Novikmec, and P. Laasonen. 2002.

Long-term recovery of stream habitat structure and benthic invertebrate communities from in-stream restoration. Biological Conservation 105:243-253.

Palik, B.J. and D. Kastendick. 2010. Response of seasonal pond plant communities to upland forest harvest in northern Minnesota forests, USA. Forest Ecology and Management 260:628-637.

Palmer, M.A., R. Ambrose, and N.L. Poff.1997.Ecological theory and community restoration ecology. Journal of Restoration Ecology 5: 291-300.

Palmer M.A., E.S. Bernhardt, J.D. Allan et al. 2005. Standards for ecologically successful river restoration. The Journal of Applied Ecology 42:208-217.

Palmer, M. A., E.S.Bernhardt, W.H. Schlesinger, K.N. Eshleman, E.FoufoulaGeorgiou, M.S. Hendryx, A.D. Lemly, G.E. Likens, O.L. Loucks, M.E. Power, P.S. White, P.R. Wilcock. 2010. Mountaintop mining consequences. Science 327 (5962):148-149. 
Palmer, M.A., H.L. Menninger, and E.S. Bernhardt. 2010. River restoration, habitat heterogeneity and biodiversity: a failure of theory or practice? Freshwater Biology 55(1):205-222.

Paxton, K. O., and F. Stevenson. 1979. Influence of artificial structure on angler harvest from Killdeer Reservoir, Ohio. Pages 70276 in R. A. Stein and D. L. Johnson, editors. Response of fish to habitat structure in standing water. American Fisheries Society, North Central Division, Special Publication 6, Bethesda, Maryland.

Peckarsky, B. L., P. R. Fraissinet, M. A. Penton, and J. Conklin, D. J. 1990. Freshwater macroinvertebrates of Northeastern North America.CornellUniversity Press, Ithaca.

Petty, J. T., J. Freund, P. Lamothe, P. Mazik. 2001. Quantifying instream habitat in the upper Shavers Fork basin at multiple spatial scales. Proceedings of the Annual Conference of the Southeastern Association of Fish and Wildlife Agencies 55:81-94.

Petty, J. T., J. B. Fulton, M. Strager, G. T. Merovich, J. Stiles, and P. Ziemkiewicz. 2010. Landscape indicators and thresholds of stream ecological impairment in an intensively mined Appalachian watershed. Journal of the North American Benthological Society 29:1292-1309. 
Petty, J. T., and G. D. Grossman. 2004. Restricted movement by mottled sculpin (Pisces: Cottidae) in a southern Appalachian stream. Freshwater Biology $49: 631-645$

Petty J. T., P.J Lamothe, and P. M. Mazik. 2005. Spatial and seasonal dynamics of brook trout populations inhabiting a central Appalachian watershed. Transactions of the American Fisheries Society. 134:572-587.

Pond, G.J. 2010. Patterns of Ephemeroptera taxa loss in Appalachian headwater streams (Kentucky, USA). Hydrobiologia 642(1):185-201.

Pond, G. J., M. E. Passmore, F. A. Borsuk, L. Reynolds, and C. J. Rose. 2008. Downstream effects of mountaintop coal mining: comparing biological conditions using family- and genus-level macroinvertebrate bioassessment tools. Journal of the North America Benthological Society 27(3):717-737.

Pratt-Situala, B., Garde M, Burbank D, Oskin M, Heimsath A, and Gabet E. 2007. Bedload-to-suspended load ratio and rapid bedrock incision from Himalayan landslide-dam lake record. Quaternary Research 68:111-120.

Pretty, J.L., S.S.C. Harrison, D.J. Shephard, C. Smith, A.G. Hildrew and R.D. Hey 2003. River rehabilitation and fish populations: assessing the benefit of instream structures. Journal of Applied Ecology 40:251-265. 
Richardson, J. S., and R. J. Danehy. 2007. A Synthesis of the Ecology of Headwater Streams and their Riparian Zones in Temperate Forests. Forest Science 53:131-147.

Roberts, D. W. 2007. labdsv: Ordination and Multivariate Analysis for Ecology. R package version 1.3-1.

Roni, P., editor. 2005. Monitoring stream and watershed restoration. American Fisheries Society, Bethesda, Maryland.

Roni, P., T. J. Beechie, R. E. Bilby, F. E. Leonetti, M. M. Pollock, and G. R. Pess. 2002. A review of stream restoration techniques and a hierarchical strategy for prioritizing restoration in Pacific Northwest watersheds. North American Journal of Fisheries Management 22:1-20.

Roper, B. B., J. J. Dose, and J. E. Williams, 1997. Stream Restoration: Is Fisheries Biology Enough?. Fisheries 22(5):6.11.

Rosgen, D.L., 1998. The Reference Reach - A Blueprint for Natural Channel Design. In: Proc. Wetland Engineering and River Restoration Conf., ASCE, CDROM. 
Rosgen, D.L., 1994. A classification of natural rivers. Catena 22:169:199.

Rosgen, David 2006.Cross-vane, W-weir, and J-hook vane structure:

Description, design and application for stream stabilization and river restoration. Wildland Hydrology, Inc. Ft. Collins, Colorado.

Rosi-Marshall, E. J., A. H. Moerke, and G. A. Lamberti. 2006. Ecological responses to trout habitat rehabilitation in a northern Michigan stream. Environmental Management 38:99-107.

Salas, A. K. and E.B. Snyder. 2010. Diel Fish Habitat Selection in a Tributary Stream. Peer Reviewed Publications. Paper 28. http://scholarworks.gvsu.edu/biopeerpubs/28

Shaffer, A.J., M. Beirne, T. Ritchie, R. Paradis, D. Barry, and P. Crain. 2009. Fish habitat use response to anthropogenic induced changes of physical processes in the Elwha estuary, Washington, USA.Hydrobiologia 636:179-190.

Shields, F. D. Jr, S. S. Knight, N. Morin, and J. Blank. 2003. Response of fishes and aquatic habitats to sand-bed stream restoration using large woody debris. Hydrobiologia 494: 251-257. 
Simon, A., M. Doyle. M. Kondolf, F.D. Shields Jr., B. Rhoads, and M. McPhillips, 2007. Critical Evaluation of How the Rosgen Classification and Associated "Natural Channel Design" Methods Fail to Integrate and Quantify Fluvial Processes and Channel Response. Journal of the American Water Resources Association 43(5):1117-1131.

Steelhammer, Rick. "Millions planned for Coal River restoration work". The Charleston Gazette. January 27,2011.

Stewart ,G.B., H.R. Baliss, D.A. Showler, W.J. Sutherland and A.S. Pullen.2009. Effectiveness of engineered instream structure mitigation measures to increase salmonid abundance: a systematic review. Ecological Applications 19:931-941.

Sutherland, A.B., Meyer JL, Gardiner EP. 2002. Effects of land cover on sediment regime and fish assemblage structure in four southern Appalachian streams. Freshwater Biology 47:1791-805.

Sweka J.A., K.J. Hartman and J.M. Niles. 2010. Long-Term Effects of Large Woody Debris Addition on Stream Habitat and Brook Trout Populations. Journal of Fish and Wildlife Management 1(2):146-151.

Thompson, D.M. 2006.Did the pre-1980 use of instream structures improve streams: A reanalysis of historic data?.Ecological Applications 16:784-796. 
Thompson A.R., J.T Petty, and G.D. Grossman. 2001. Multi-scale effects of resource patchiness on foraging behaviour and habitat use by longnose dace, Rhinichthys cataractae. Freshwater Biology 46:145-160.

Thompson, D.M. and G.N. Stull. 2002. The development and historical use of habitat structures in channel restoration in the United States: The grand experiment in fisheries management. Ge'ographPhysQuatern 56:45-60

Tikkanen P., P. Laasonen, T. Muotka, A. Huhta, and K. Kuusela. 1994. Shortterm recovery of benthos following disturbance from stream habitat rehabilitation. Hydrobiologia 273:121-30.

Van Sickle, J. 1997. Using mean similarity dendrograms to evaluate classifications. Journal of Agricultural, Biological, and Environmental Statistics 2(4):370-388.

Van Sickle, J. and R. M. Hughes. 2000. Classification strengths of ecoregions, catchments and geographic clusters for aquatic vertebrates in Oregon. Journal of the North American Benthological Society 19(3):370-384.

van Zyll De Jong, M. C., I.G. Cox, and D.A. Scruton. 1997. An evaluation of instream habitat restoration techniques on salmonid populations in a 
Newfoundland stream. Regulated Rivers Research and Management 13:603614.

Wallace, J. B., J. R. Webster, and T. F. Cuffney.1982. Stream detritus dynamics: regulation by invertebrate consumers. Oecologia 53:197-200.

Warren, D.R., M.M. Mineau, E.J. Ward, C.E. Kraft. 2010. Relating fish biomass to habitat and chemistry in headwater streams of the northeastern United States. Environmental Biology of Fishes 88(1):51-62.

Weber-Scannell, P. K., and L.K. Duffey. 2007. Effects of total dissolved solids on aquatic organisms: a review of literature and recommendation for salmonid species. American Journal of Environmental Sciences 3:1-6.

West Virginia Department of Environmental Protection, West Virginia Save Our Streams Advanced Stream Assessment Manual (Charleston, WV: West Virginia Department of Environmental Protection, Division of Water and Waste Management, 2004).

Whiteway, S. L., P. M. Biron, A. Zimmermann, O. Venter, and J. W. A. Grant. 2010. Do instream restoration structures enhance salmonid abundance? A metaanalysis. Canadian Journal of Fisheries and Aquatic Sciences 67:831-841. 
Wilbur, R.L. (1978) Two Types of Fish Attractors Compared in Lake

Tohopekaliga, Florida. Transactions of the American Fisheries Society 107:689695.

Wiley J.B., R.D. Evaldi, J.H. Eychaner, and D.B. Chambers, Reconnaissance of Stream Geomorphology, Low Streamflow, and Stream Temperature in the Mountaintop Coal-Mining Region, Southern West Virginia, 1999-2000 (Charleston, WV: U.S. Department of the Interior, U.S. Geological Survey, in cooperation with the West Virginia Department of Environmental Protection, Office of Mining and Reclamation,Water-Resources Investigations Report 014092, 2001)

Wipfli, M.S., J.S. Richardson, and R.J. Naiman. 2007. Ecological linkages between headwaters and downstream ecosystems: Transport of organic matter, invertebrates, and wood down headwater channels. Journal of American Water Resources Association 43:72- 85.

Zhou P., O. Luukkanen, T. Tokola, and J. Nieminen. 2008. Effect of vegetation cover on soil erosion in a mountainous watershed. Catena 75:319-325. 


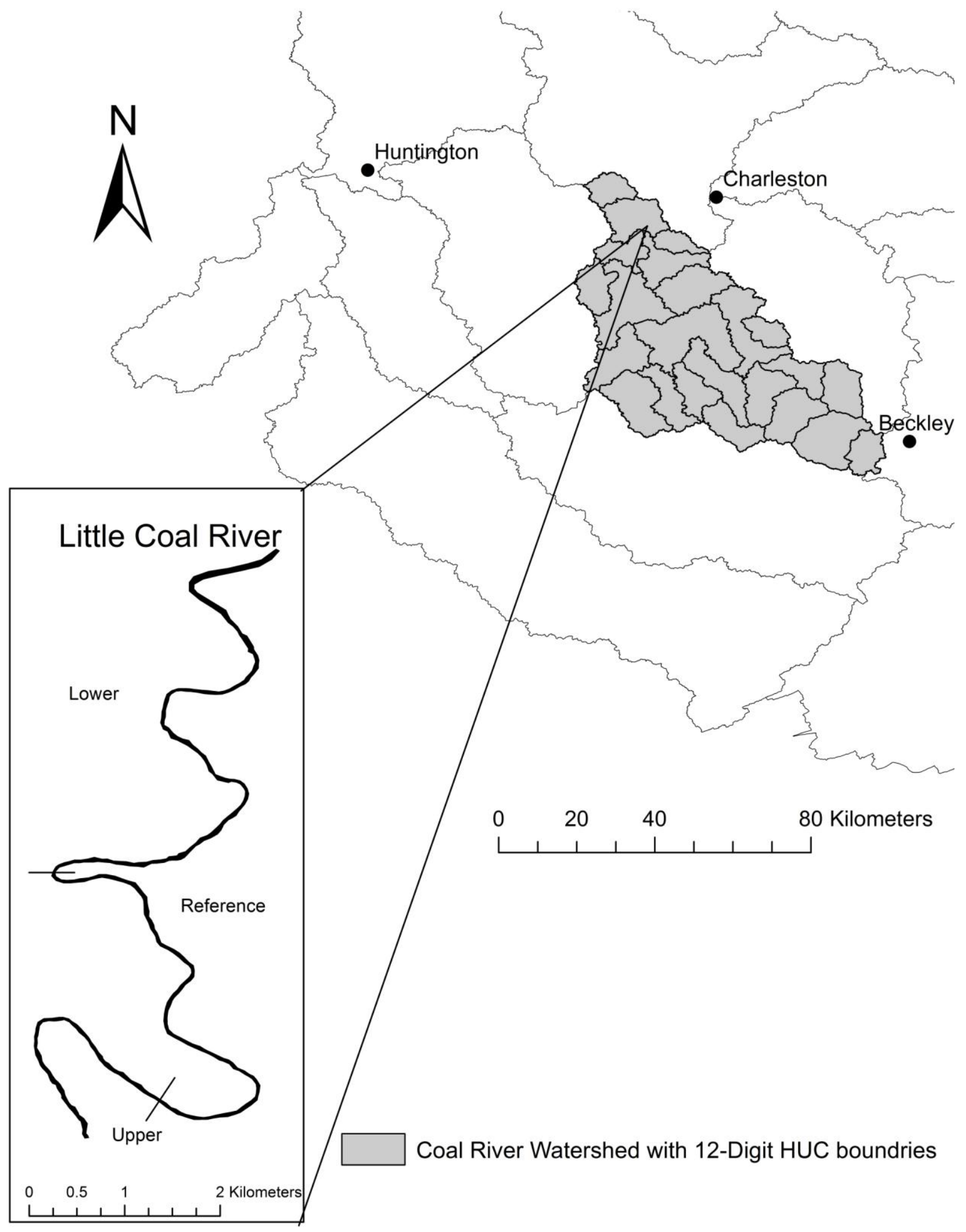

Figure 1. Location of study area and upper treatment, lower treatment, and reference reaches. 
A.
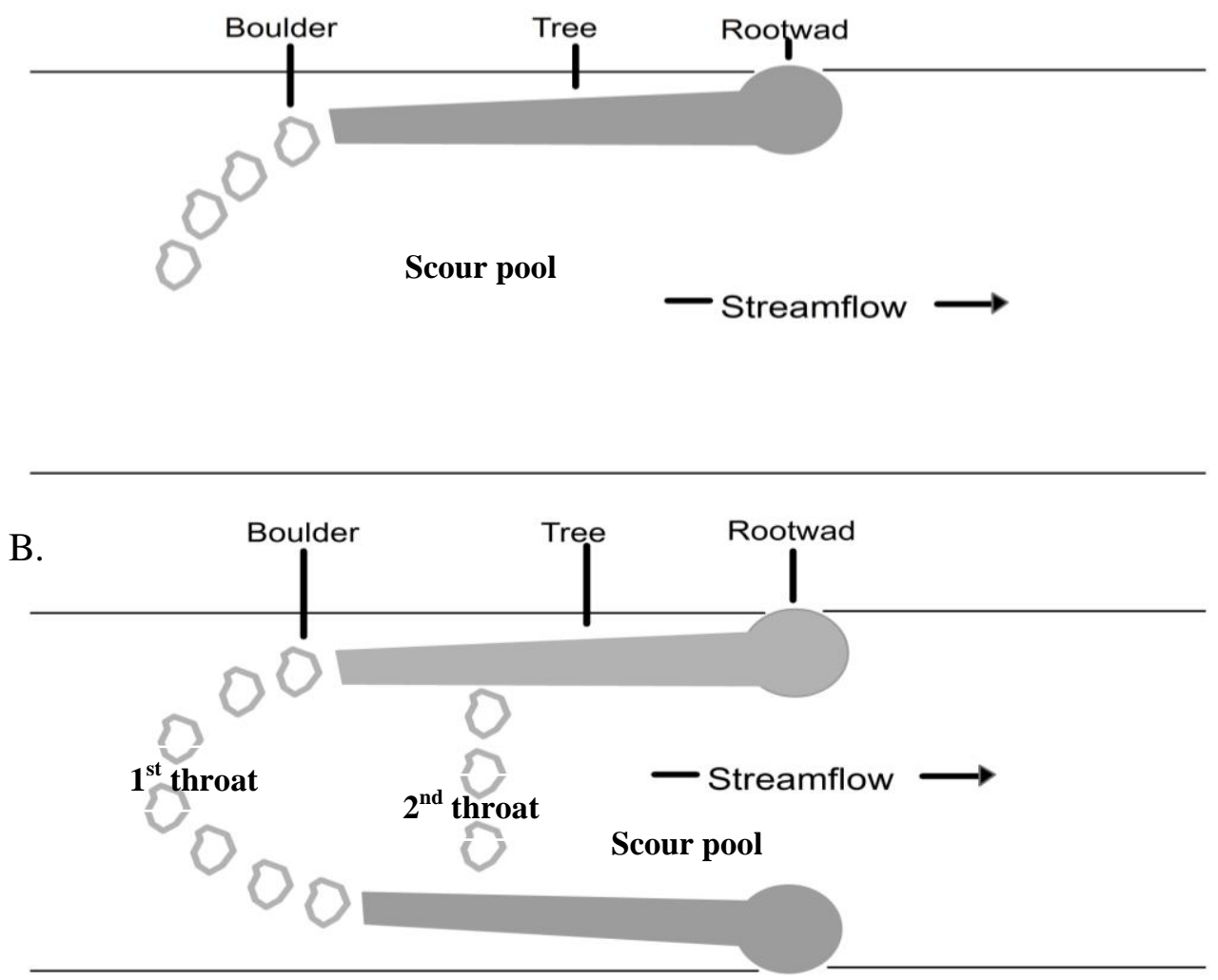

Figure 2. Diagrammatic representations of habitat enhancing structures (A. J-hook and B. cross-vane) 


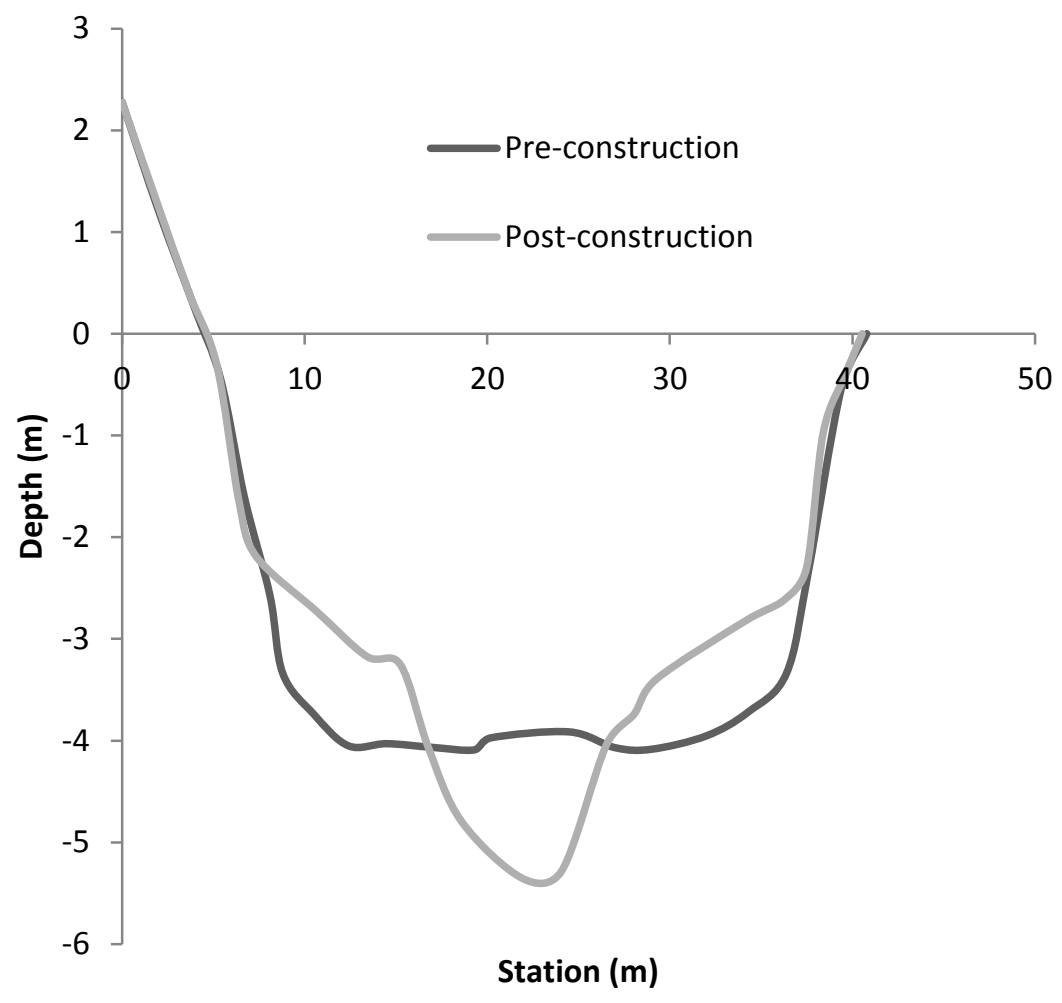

Figure 3. Representative cross-sectional survey conducted in the lower subreach (dark line represents the 2009 cross-section before the structure was placed and the light line represents the cross-section in 2010 after the structure was in place; cross-section was conducted "at rootwad". 
Table 1. Little Coal River water quality results with respect to year, season, and reach (dots represent missing values).

\begin{tabular}{|c|c|c|c|c|c|c|c|c|c|c|c|}
\hline Reach & $\begin{array}{c}\text { Conductivity } \\
\mu \mathrm{S} / \mathrm{cm}\end{array}$ & $\begin{array}{l}\text { Acidity } \\
\mathrm{mg} / \mathrm{L}\end{array}$ & $\begin{array}{c}\mathrm{Al} \\
\mathrm{mg} / \mathrm{L}\end{array}$ & $\begin{array}{c}\text { Alkalinity } \\
\mathrm{mg} / \mathrm{L}\end{array}$ & $\begin{array}{l}\mathrm{Ca} \\
\mathrm{mg} / \mathrm{L}\end{array}$ & $\begin{array}{c}\mathrm{Cd} \\
\mathrm{mg} / \mathrm{L}\end{array}$ & $\begin{array}{c}\mathrm{Cl} \\
\mathrm{mg} / \mathrm{L}\end{array}$ & $\begin{array}{c}\mathrm{Co} \\
\mathrm{mg} / \mathrm{L}\end{array}$ & $\begin{array}{c}\mathrm{Cr} \\
\mathrm{mg} / \mathrm{L}\end{array}$ & $\begin{array}{c}\mathrm{Cu} \\
\mathrm{mg} / \mathrm{L}\end{array}$ & $\begin{array}{c}\mathrm{Fe} \\
\mathrm{mg} / \mathrm{L}\end{array}$ \\
\hline \multicolumn{12}{|l|}{ Spring 2009} \\
\hline Upper & 693 & $<1$ & 0.85 & 138.14 & 56.4 & $<0.014$ & 13 & $<0.015$ & $<.012$ & 0.017 & 0.057 \\
\hline Reference & 667 & $<1$ & 0.066 & 145.36 & 52.73 & $<0.014$ & 13.09 & $<0.015$ & $<.012$ & $<0.015$ & 0.078 \\
\hline Lower & 701 & $<1$ & 0.071 & 143.58 & 56.57 & $<0.014$ & 13.7 & $<0.015$ & $<.012$ & $<0.015$ & 0.078 \\
\hline $\begin{array}{r}\text { Fall } 2009 \\
\text { Upper }\end{array}$ & 813 & $<1$ & 0.082 & 252.09 & 61.15 & $<0.014$ & 16.56 & $<0.015$ & 0.06 & 0.323 & 0.265 \\
\hline Reference & 790 & $<1$ & 0.067 & 229.98 & 53.19 & $<0.014$ & 16.39 & $<0.015$ & $<0.012$ & 0.025 & 1.07 \\
\hline Lower & 832 & $<1$ & 0.045 & 234.58 & 56.35 & $<0.014$ & 17.04 & 0.018 & $<0.012$ & 0.022 & 0.056 \\
\hline \multicolumn{12}{|l|}{ Spring 2010} \\
\hline Upper & 739 & $<1$ & $<0.021$ & 156.82 & 48.49 & $<0.014$ & 13.97 & $<0.015$ & $<0.012$ & $<0.015$ & 0.17 \\
\hline Reference & 725 & $<1$ & $<0.021$ & 117.42 & . & $<0.014$ & 9.79 & $<0.015$ & $<0.012$ & $<0.015$ & 0.14 \\
\hline Lower & 687 & $<1$ & $<0.021$ & 156.65 & 47.99 & $<0.014$ & 12.88 & $<0.015$ & $<0.012$ & $<0.015$ & 0.21 \\
\hline $\begin{array}{l}\text { Fall } 2010 \\
\text { Upper }\end{array}$ & 1030 & $<1$ & $<0.1$ & 351.32 & 45.42 & $<0.014$ & 36.7 & $<0.015$ & $<0.012$ & $<0.015$ & $<0.1$ \\
\hline Reference & 1068 & $<1$ & $<0.1$ & 324.27 & 37.08 & $<0.014$ & 36.8 & $<0.015$ & $<0.012$ & $<0.015$ & $<0.1$ \\
\hline Lower & 1027 & $<1$ & $<0.1$ & 338.17 & 37.93 & $<0.014$ & 36.5 & $<0.015$ & $<0.012$ & $<0.015$ & $<0.1$ \\
\hline
\end{tabular}


Table 1. Continued.

\begin{tabular}{|c|c|c|c|c|c|c|c|c|c|}
\hline Reach & $\begin{array}{c}\mathrm{Mg} \\
\mathrm{mg} / \mathrm{L}\end{array}$ & $\begin{array}{c}\mathrm{Mn} \\
\mathrm{mg} / \mathrm{L}\end{array}$ & $\begin{array}{c}\mathrm{Na} \\
\mathrm{mg} / \mathrm{L}\end{array}$ & $\begin{array}{c}\mathrm{Ni} \\
\mathrm{mg} / \mathrm{L}\end{array}$ & $\begin{array}{c}\mathrm{Se} \\
\mathrm{mg} / \mathrm{L}\end{array}$ & $\begin{array}{l}\mathrm{SO} 4 \\
\mathrm{mg} / \mathrm{L}\end{array}$ & $\begin{array}{l}\mathrm{TDS} \\
\mathrm{mg} / \mathrm{L}\end{array}$ & $\begin{array}{l}\mathrm{TSS} \\
\mathrm{mg} / \mathrm{L}\end{array}$ & $\begin{array}{c}\mathrm{Zn} \\
\mathrm{mg} / \mathrm{L}\end{array}$ \\
\hline \multicolumn{10}{|l|}{ Spring 2009} \\
\hline Upper & 35.83 & 0.043 & 98.96 & $<0.019$ & $<0.045$ & 209 & 138 & 43 & $<0.016$ \\
\hline Reference & 33.88 & 0.042 & 92.2 & $<0.019$ & $<0.045$ & 208 & 124 & 35 & $<0.016$ \\
\hline Lower & 35.79 & 0.038 & 122.82 & 0.019 & 0.047 & 224 & 604 & 6 & 0.026 \\
\hline \multicolumn{10}{|l|}{ Fall 2009} \\
\hline Upper & 37.64 & 0.07 & 126.91 & 0.047 & $<0.045$ & 253 & 649 & 22 & 0.546 \\
\hline Reference & 32.82 & 0.054 & 111.94 & 0.153 & 0.181 & 249 & 638 & 20 & $<0.016$ \\
\hline Lower & 34.3 & $<0.017$ & 107.94 & 0.038 & $<0.045$ & 235 & 575 & 15 & $<0.016$ \\
\hline \multicolumn{10}{|l|}{ Spring 2010} \\
\hline Upper & 26.76 & $<0.1$ & 72.75 & $<0.019$ & $<0.045$ & 200 & 493 & 17 & $<0.016$ \\
\hline Reference & $\cdot$ & $<0.1$ & 2.22 & $<0.019$ & $<0.045$ & 138 & 320 & 8 & $<0.016$ \\
\hline Lower & 27.61 & $<0.1$ & 76.69 & $<0.019$ & 0.051 & 188 & 480 & 7 & $<0.016$ \\
\hline \multicolumn{10}{|l|}{ Fall 2010} \\
\hline Upper & 27.99 & $<0.1$ & 196 & $<0.019$ & $<0.045$ & 337 & 880 & 3 & 0.035 \\
\hline Reference & 25.58 & $<0.1$ & 197 & $<0.019$ & $<0.045$ & 328 & 834 & $<2.37$ & $\cdot$ \\
\hline Lower & 28.44 & $<0.1$ & 201 & $<0.019$ & $<0.045$ & 338 & 834 & $<2.37$ & 0.025 \\
\hline
\end{tabular}


Table 2. Mean depth, coefficient of variation (CV) of water depth, mean distance to fish cover (DFC) in 2009 and 2010 of entire study reach and sub-reaches.

Standard error is in parenthesis.

\begin{tabular}{lcccccc}
\hline & \multicolumn{2}{c}{ Mean Depth $(\mathrm{m})$} & \multicolumn{2}{c}{ CV of depth } & \multicolumn{2}{c}{ DFC $(\mathrm{m})$} \\
\multicolumn{1}{c}{ Reach } & 2009 & 2010 & 2009 & 2010 & 2009 & 2010 \\
\hline Entire River & $0.93(0.0072)$ & $0.94(0.0086)$ & 0.48 & 0.58 & $16.15(0.53)$ & $14.44(0.59)$ \\
Upper & $0.56(0.003)$ & $0.5(0.0015)$ & 0.92 & 0.52 & $16.12(2.44)$ & $15.24(1.24)$ \\
Reference & $0.8(0.0027)$ & $0.76(0.0026)$ & 0.59 & 0.6 & $12.54(1.4)$ & $19.69(2.72)$ \\
Lower & $0.75(0.002)$ & $0.92(0.0026)$ & 0.46 & 0.48 & $22.07(2.45)$ & $11.19(2.01)$ \\
\hline
\end{tabular}



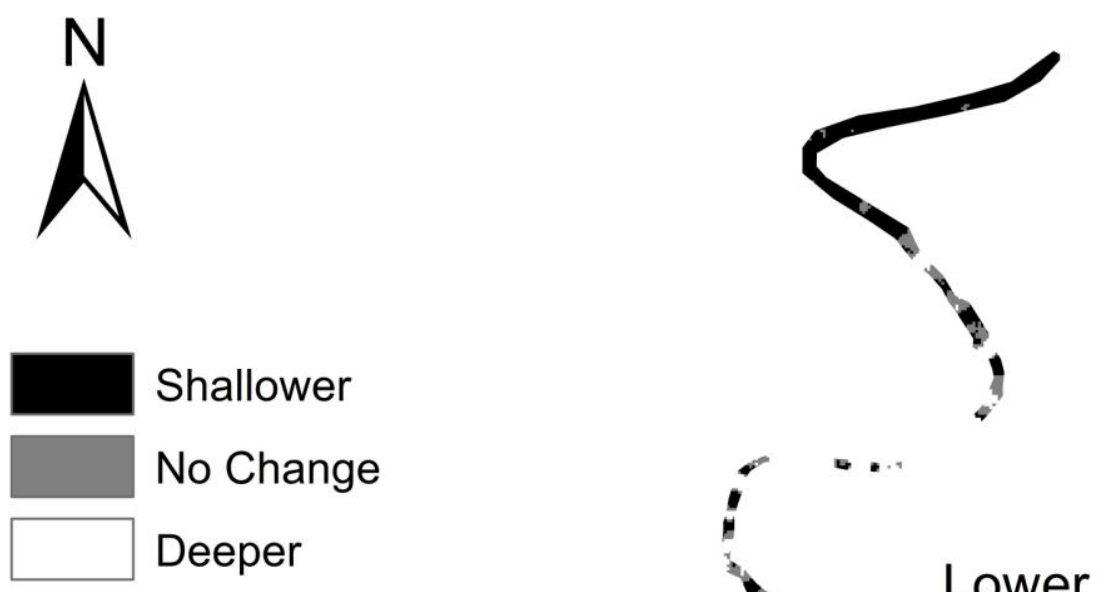

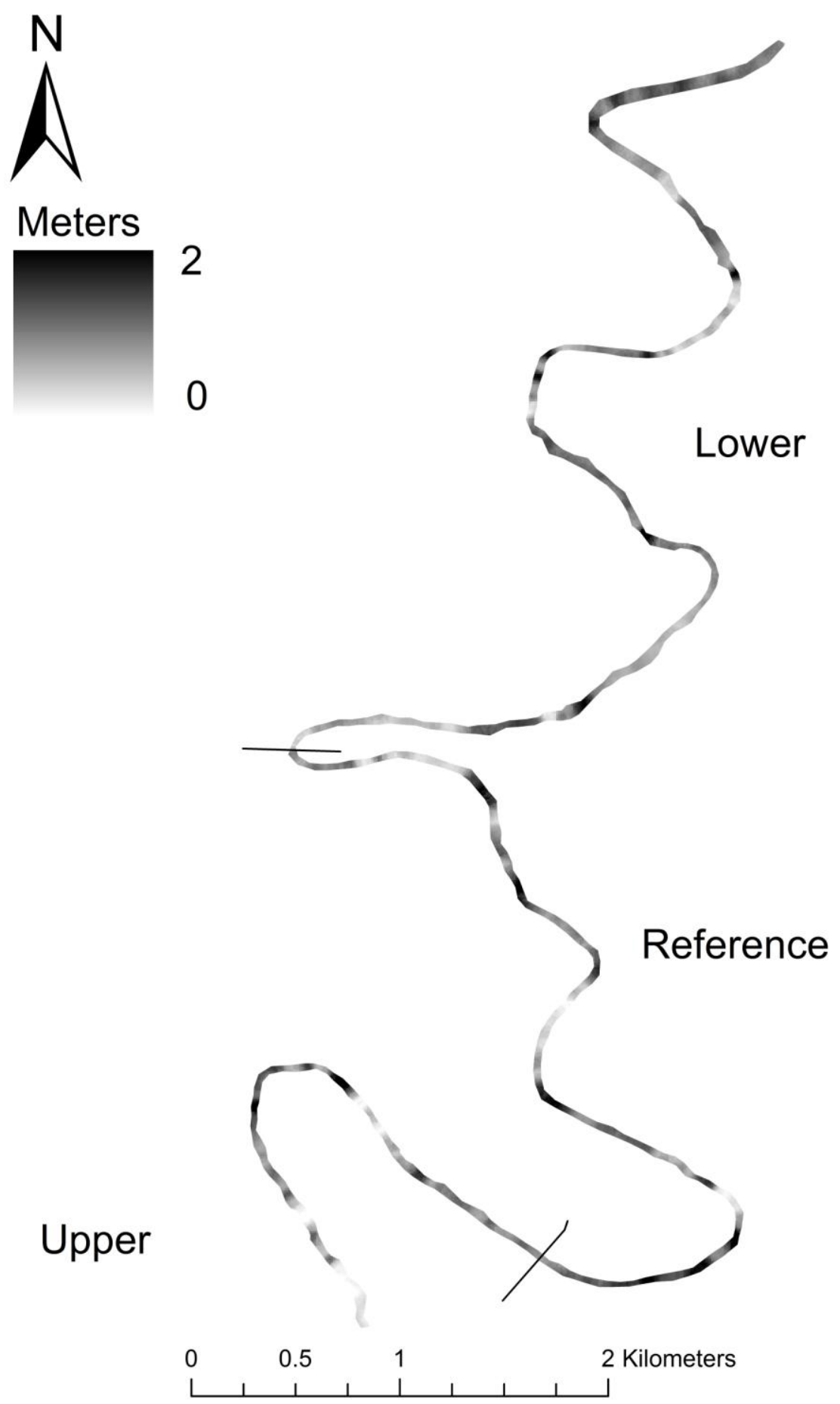

Figure 5. Depth mapping of the lower $13.7 \mathrm{~km}$ of the Little Coal River in 2009 (lighter colors indicate shallower areas and darker colors indicate the deeper segments). 

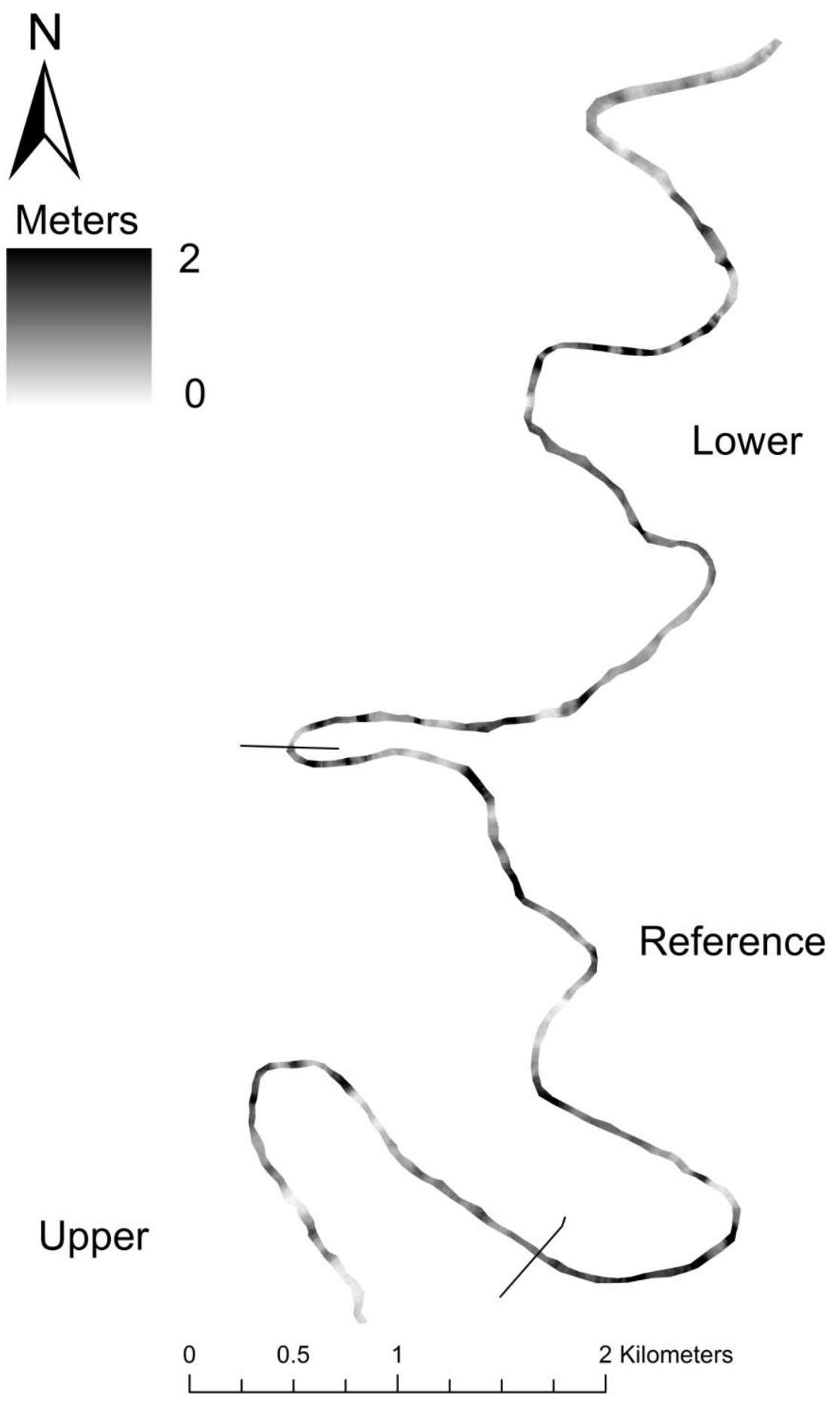

Figure 6. Depth mapping of the lower $13.7 \mathrm{~km}$ of the Little Coal River in 2010 (lighter colors indicate sallower areas and darker colors indicate the deeper segments). 


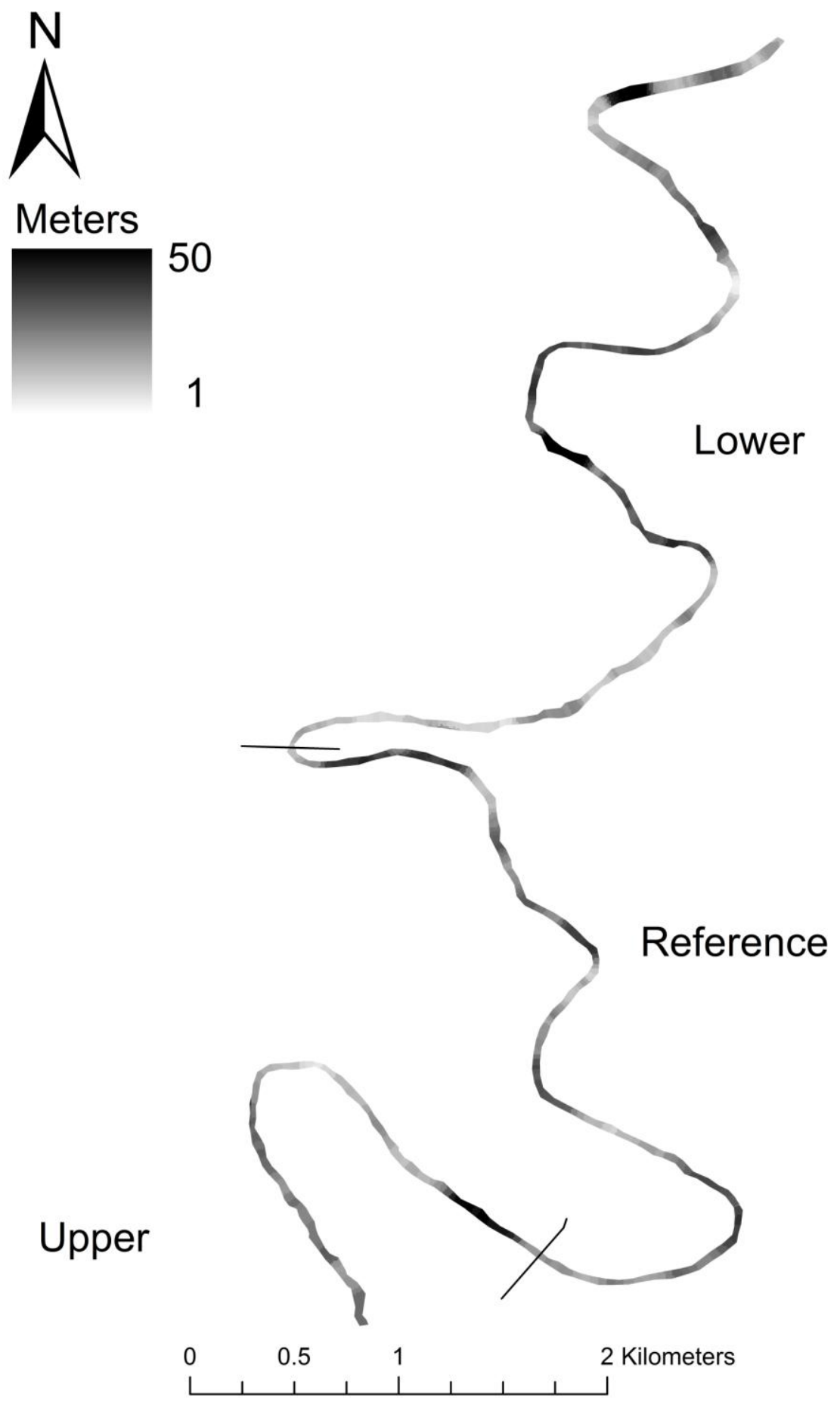

Figure 7. Distance to nearest fish cover in the lower $13.7 \mathrm{~km}$ of the Little Coal River in 2009 (lighter colors indicate areas with close fish cover and darker colors indicate areas of further fish cover). 


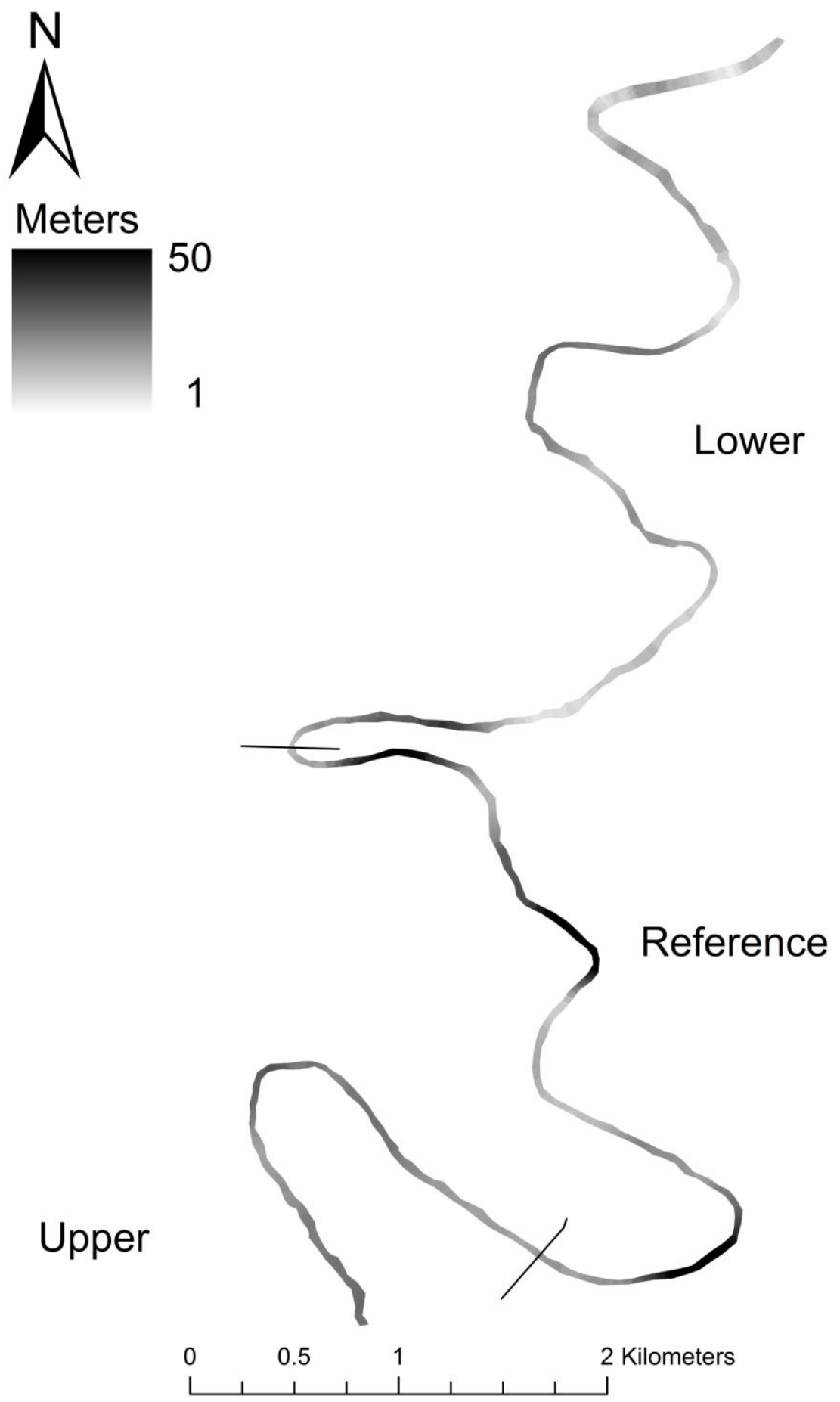

Figure 8. Distance to nearest fish cover in the lower $13.7 \mathrm{~km}$ of the Little Coal River in 2010 (lighter colors indicate areas with close fish cover and darker colors indicate areas of further fish cover). 


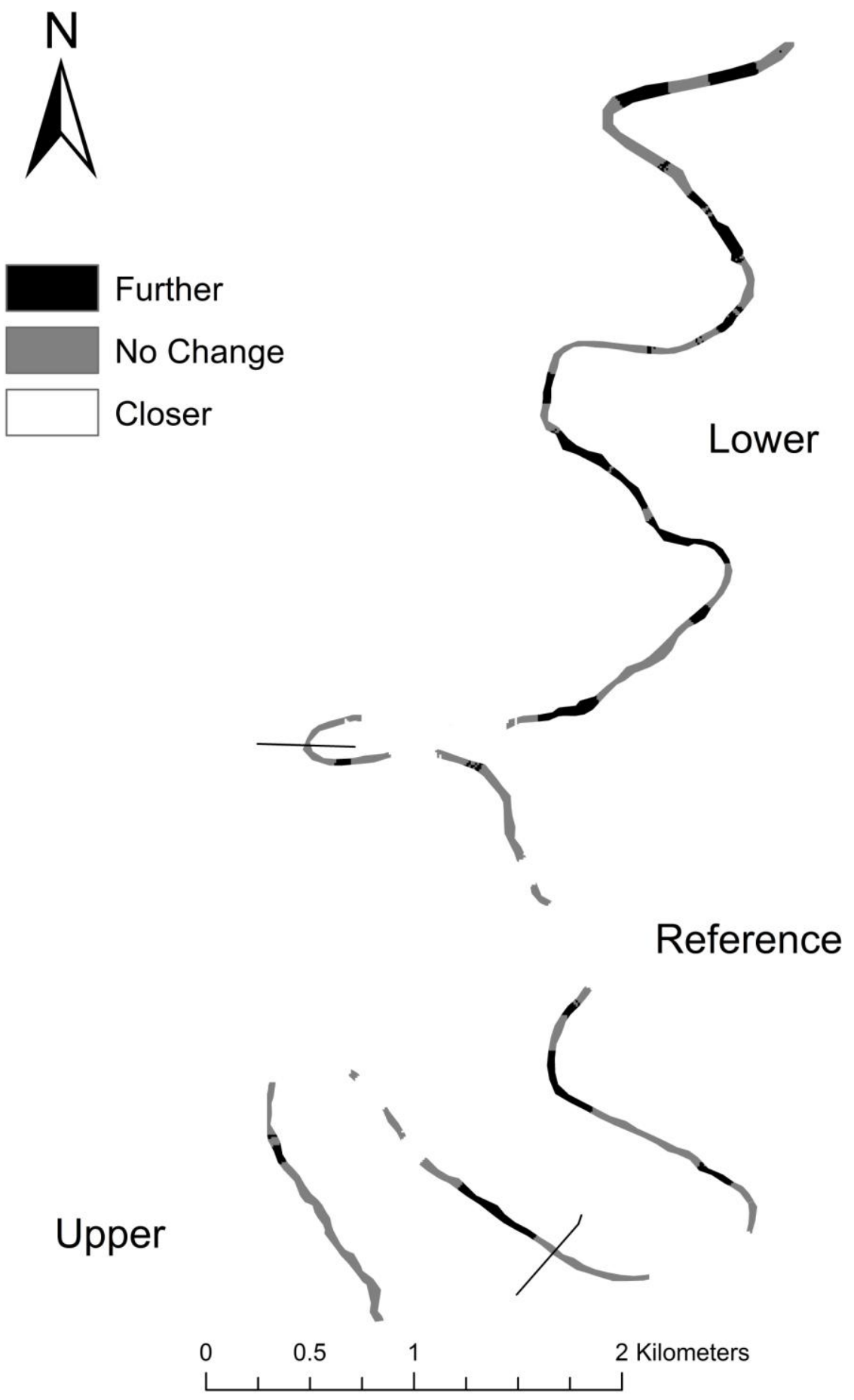

Figure 9. Change in distance to fish cover of the lower $13.7 \mathrm{~km}$ of the Little Coal River between 2009-2010. 
Table 3. Percent of substrate type within entire study reach and sub-reaches during pre-construction (2009) and post-construction (2010) periods.

\begin{tabular}{clcccc}
\hline \multicolumn{2}{c}{ Substrate } & Entire River & Upper & Reference & Lower \\
\hline \multirow{2}{*}{2009} & Sand & 48 & 17 & 47 & 61 \\
& Gravel & 30 & 58 & 32 & 28 \\
& Cobble & 15 & 19 & 13 & 8 \\
& Boulder & 7 & 6 & 8 & 3 \\
\hline \multirow{2}{*}{2010} & Sand & 51 & 24 & 47 & 46 \\
& Gravel & 29 & 54 & 30 & 39 \\
& Cobble & 15 & 19 & 17 & 12 \\
& Boulder & 5 & 3 & 6 & 3 \\
\hline \multirow{2}{*}{ Change } & Sand & +3 & +7 & 0 & -15 \\
& Gravel & -1 & -4 & -2 & +11 \\
& Cobble & 0 & 0 & +4 & +4 \\
& Boulder & -2 & -3 & -2 & 0 \\
\hline
\end{tabular}




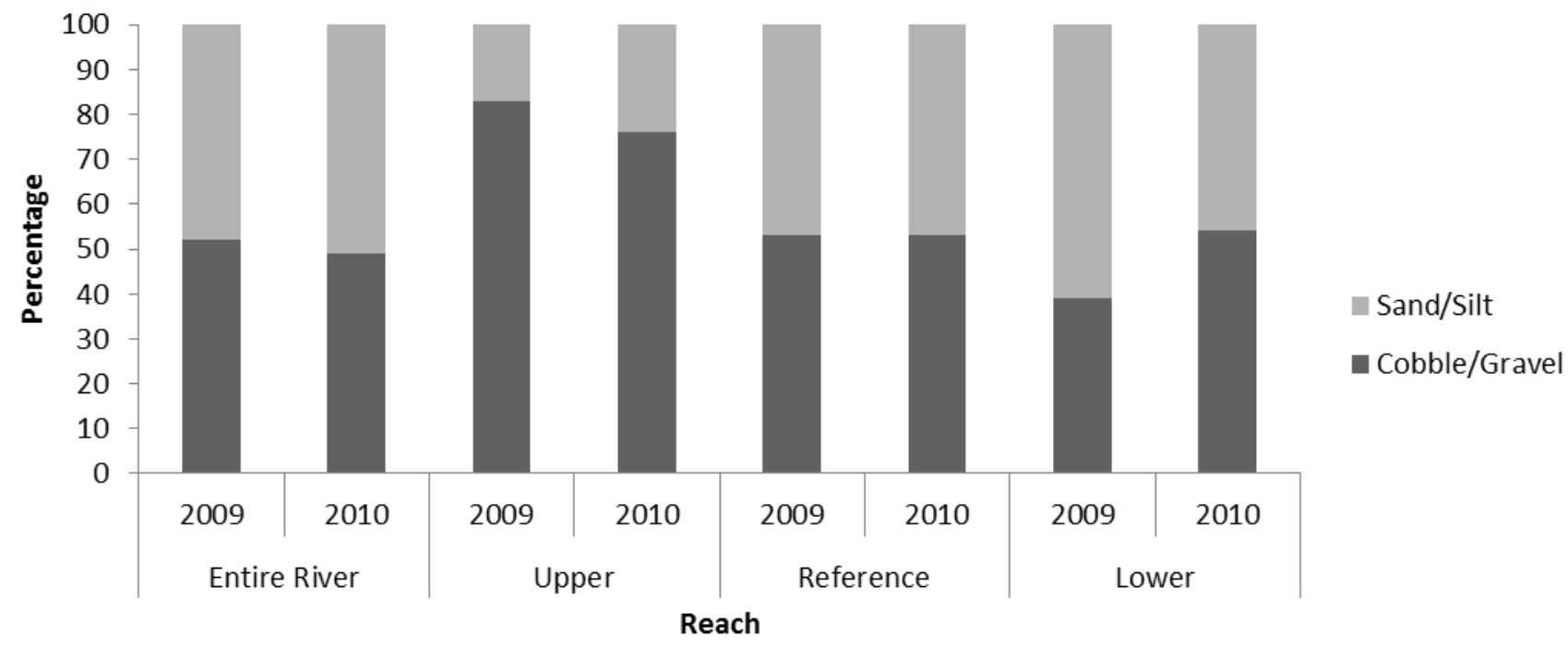

Figure 10. Changes in substrate composition between years and sub-reaches. 

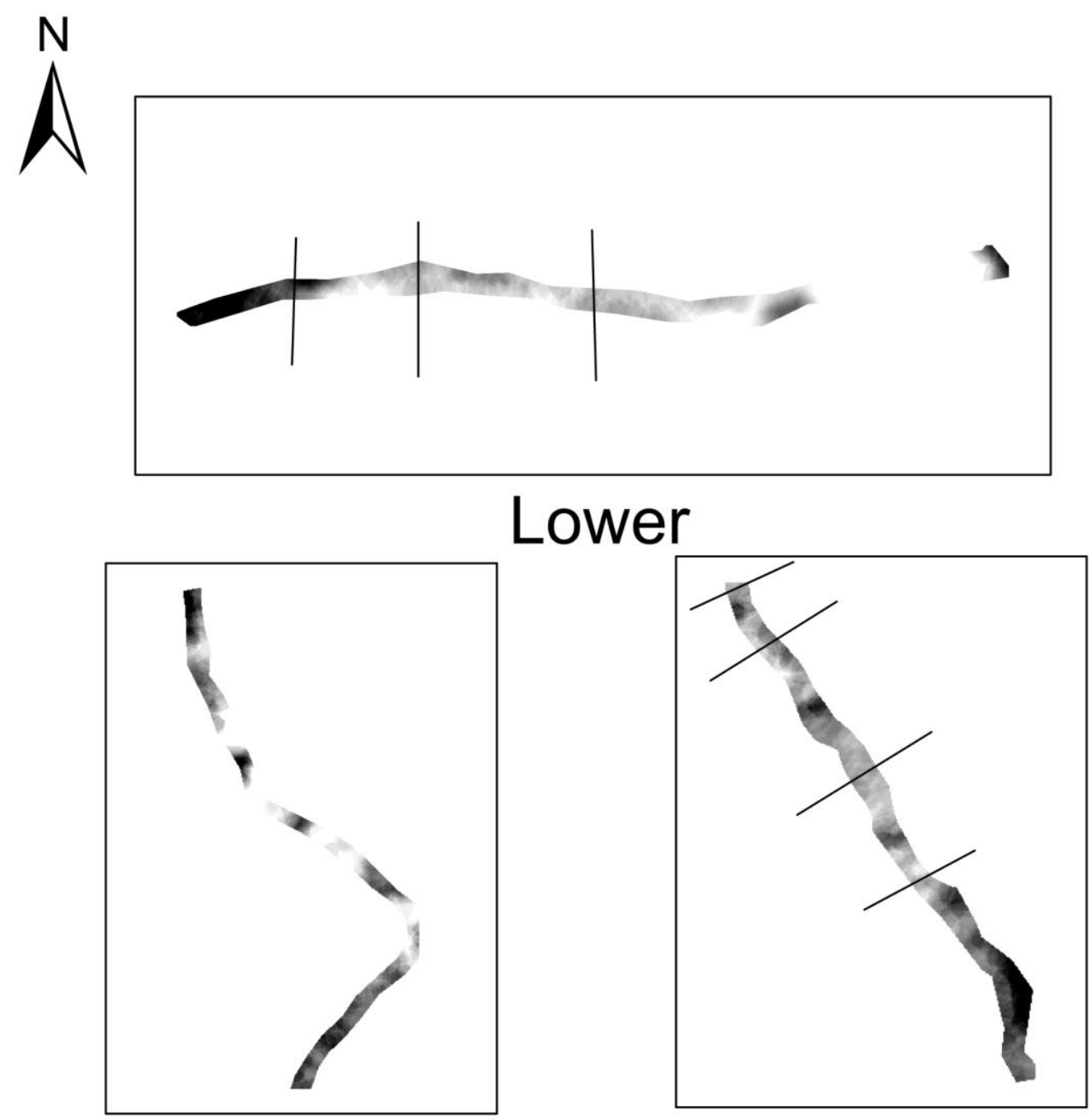

Reference

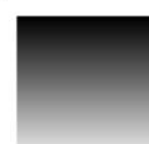

Boulder Upper

Sand

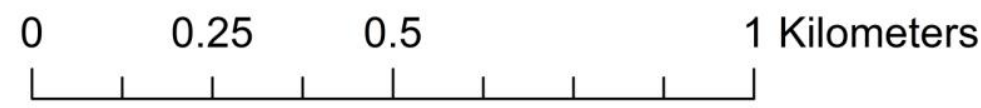

Figure 11. Substrate mapping of sub-reaches in 2009, lines represent structure locations (lighter colors indicate poor substrate for habitat use and darker colors indicate best substrate type for habitat use). 

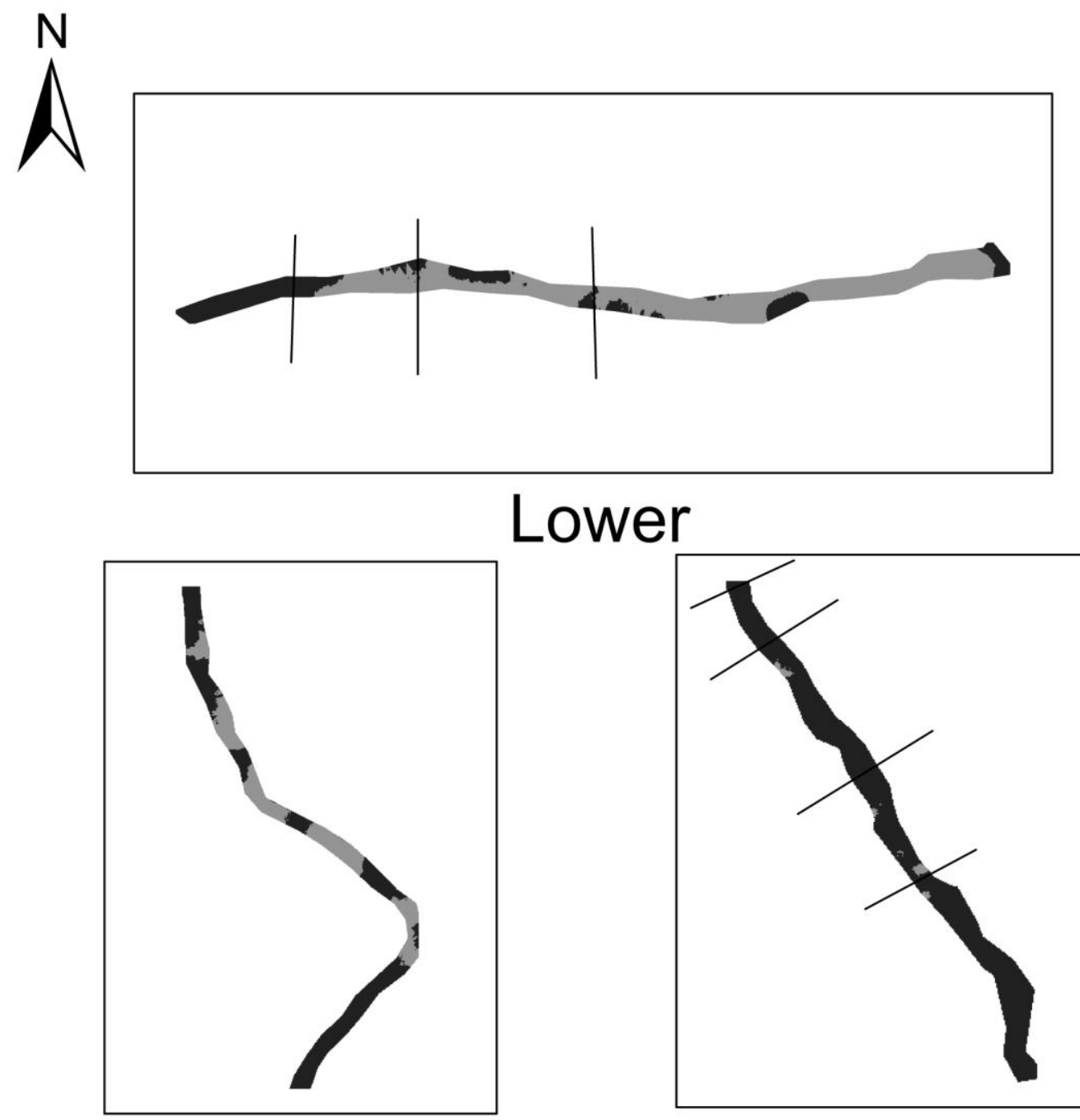

Reference

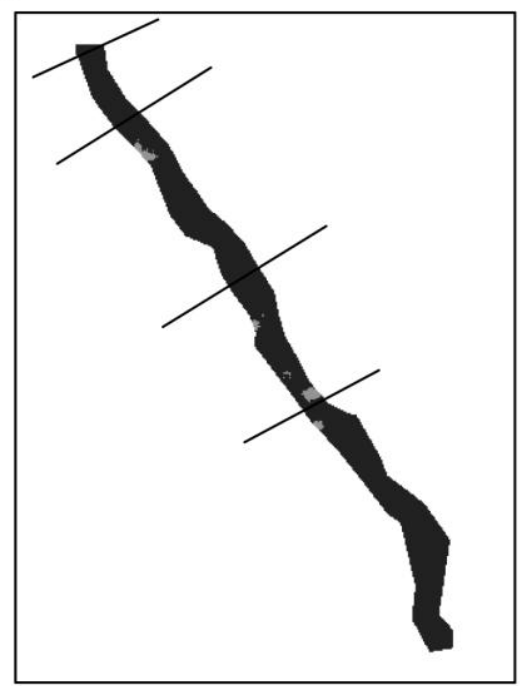

Upper

Sand

Not Sand

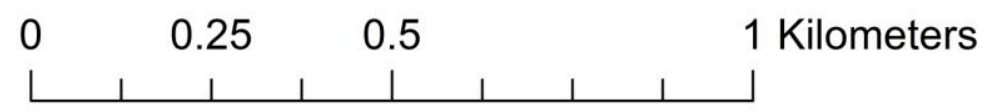

Figure 12. Substrate mapping of sub-reaches in 2009, lines represent structure locations (gray indicates sand substrate and black indicates gravel, cobble, and boulder substrates). 

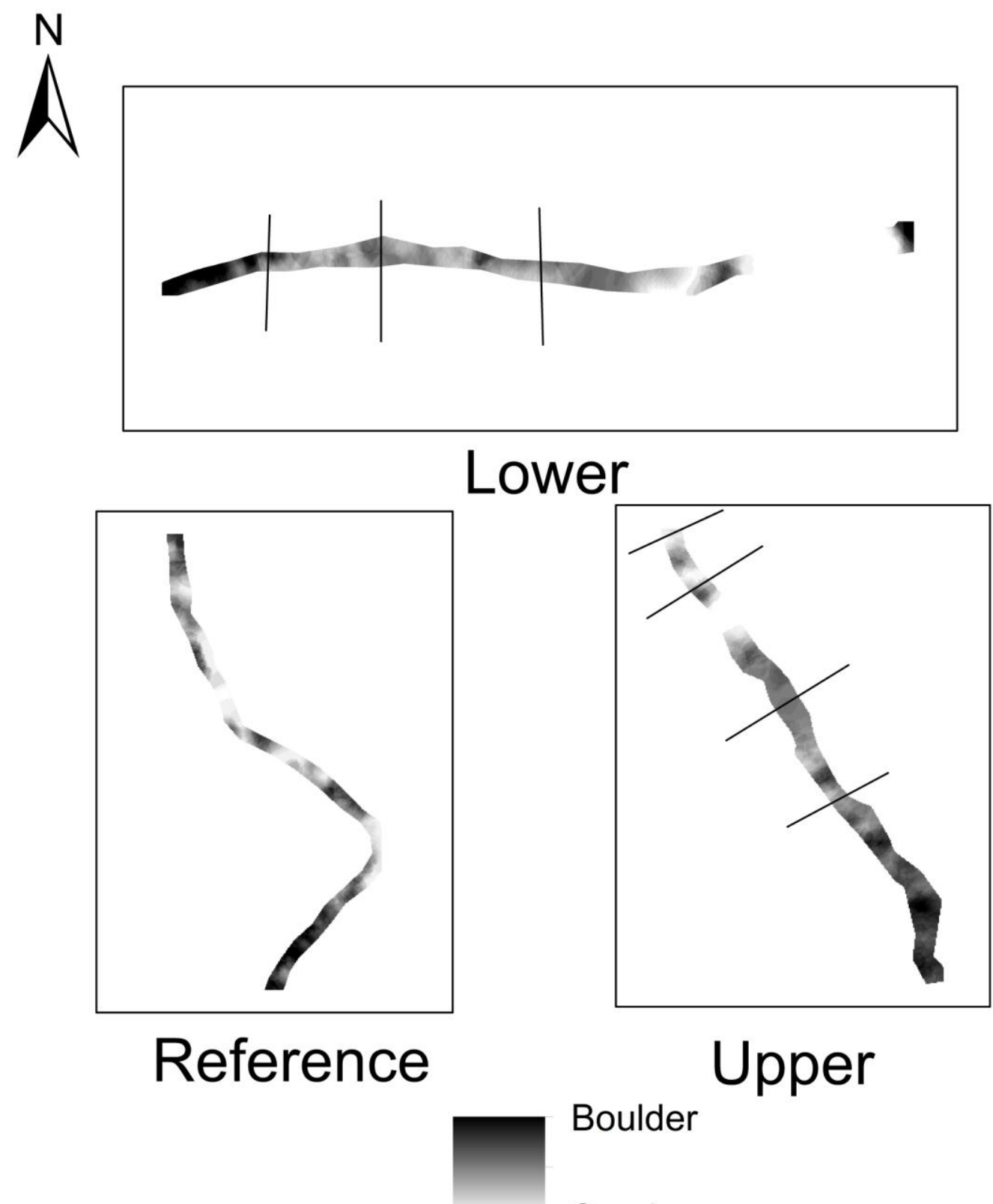

Boulder

Sand

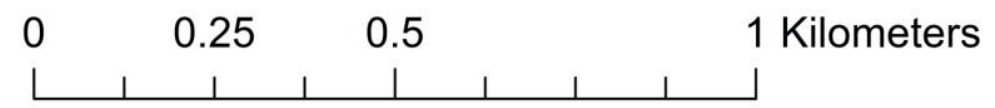

Figure 13. Substrate mapping of sub-reaches in 2010, lines represent structure locations (lighter colors indicate poor substrate for habitat use and darker colors indicate best substrate type for habitat use). 

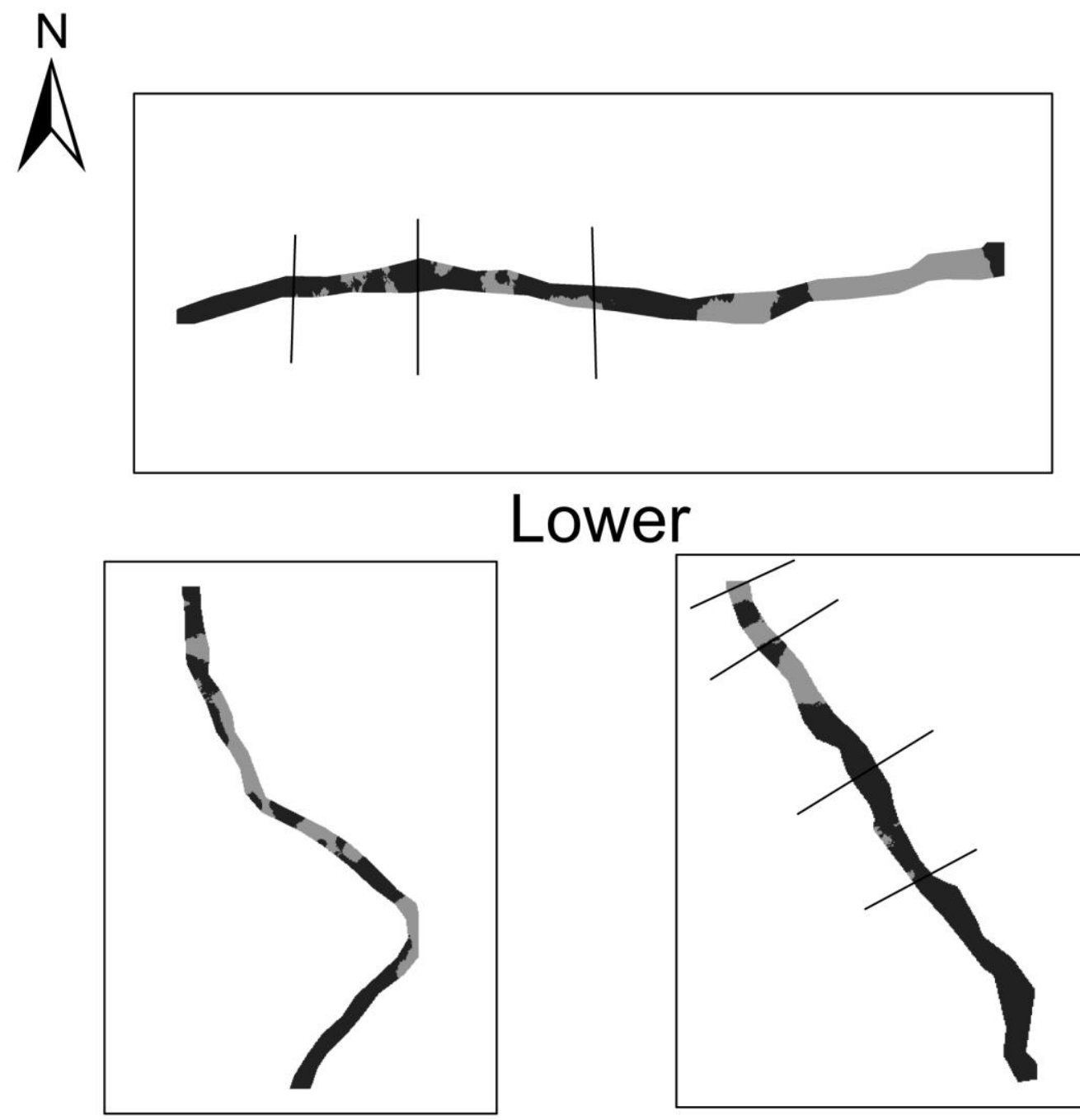

Reference

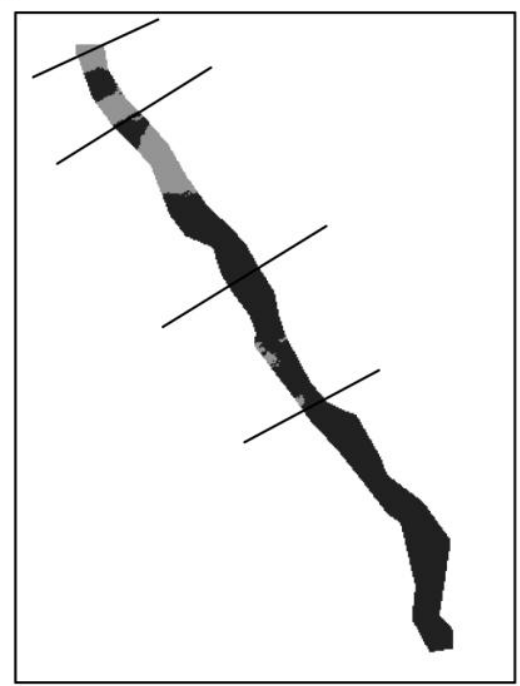

\section{Upper}

Sand

Not Sand

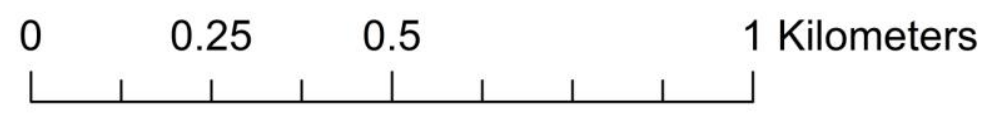

Figure 14. Substrate mapping of sub-reaches in 2010, lines represent structure locations (gray indicates sand substrate and black indicates gravel, cobble, and boulder substrates). 

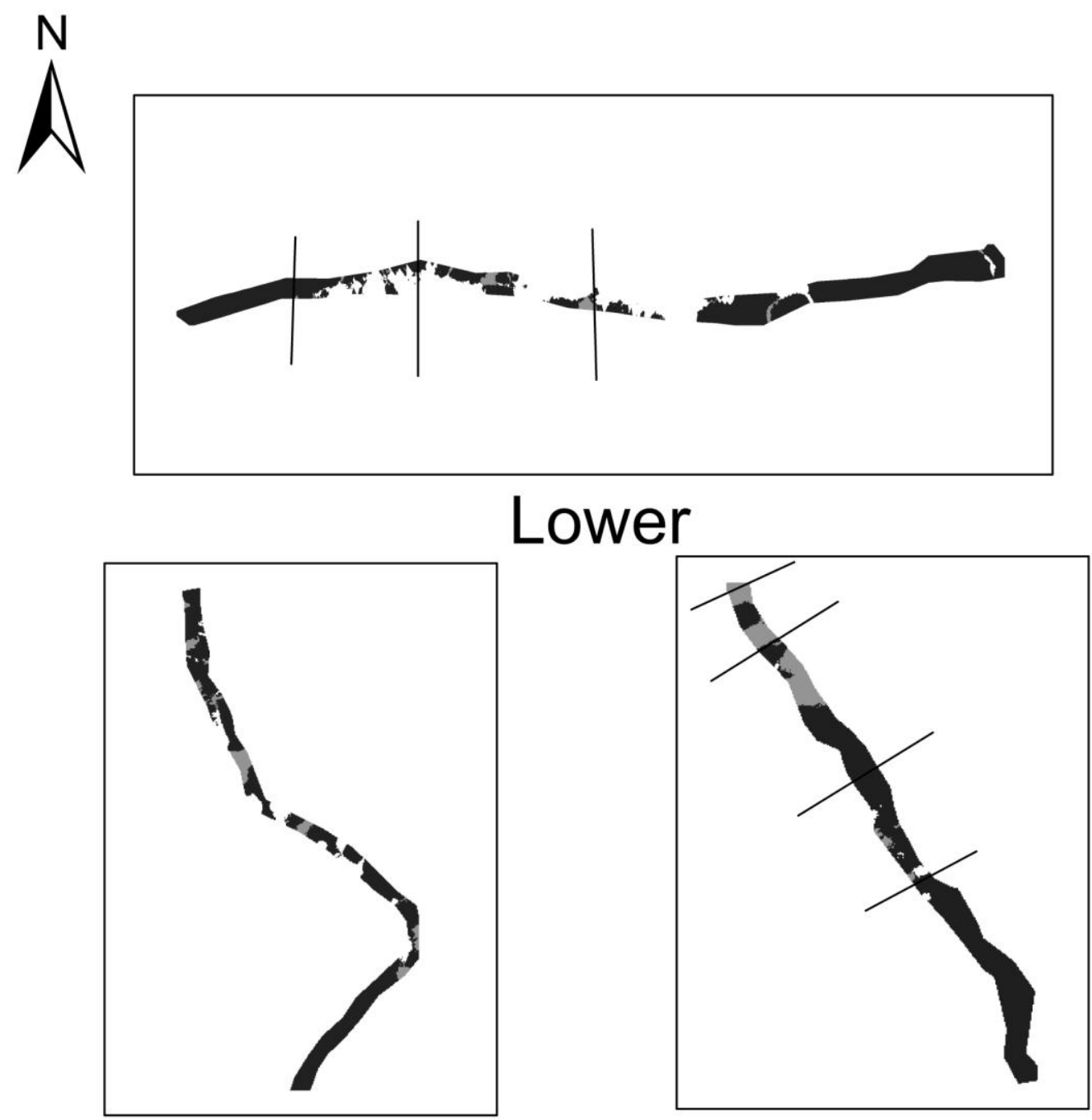

Reference
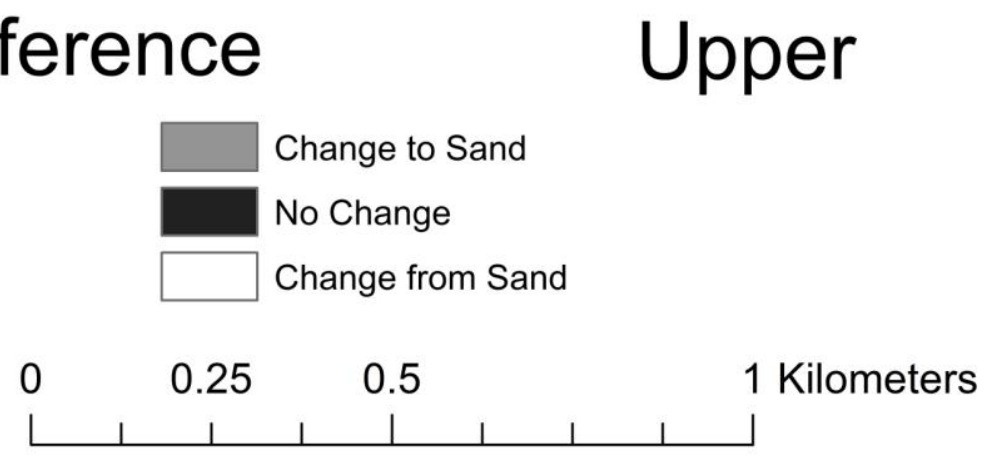

Figure 15. Change in substrate composition of sub-reaches between 2009-2010, lines represent structure locations. 

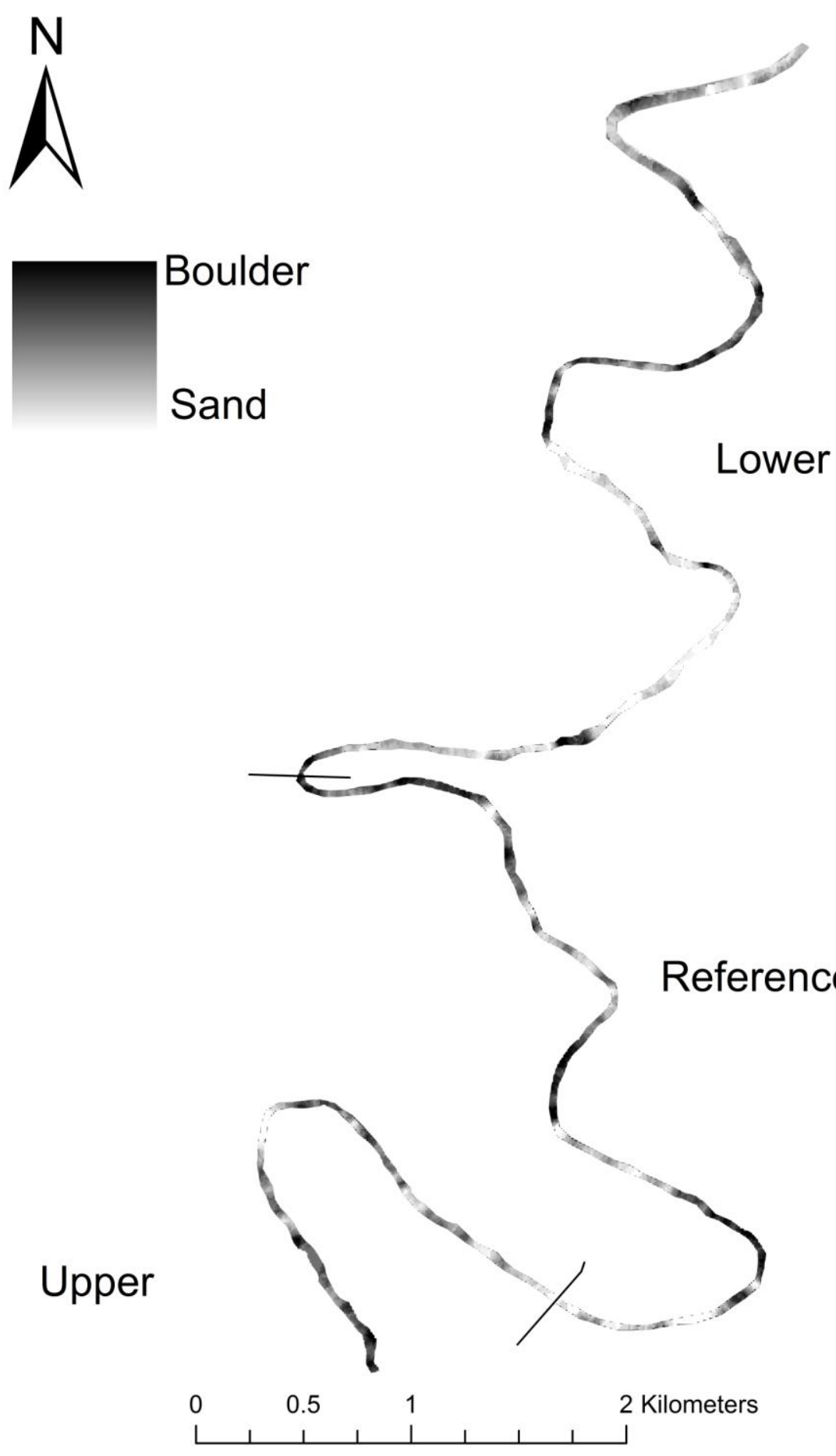

Figure 16. Substrate mapping of the lower $13.7 \mathrm{~km}$ of the Little Coal River in 2009 (lighter colors indicate poor substrate for habitat use and darker colors indicate best substrate type for habitat use). 

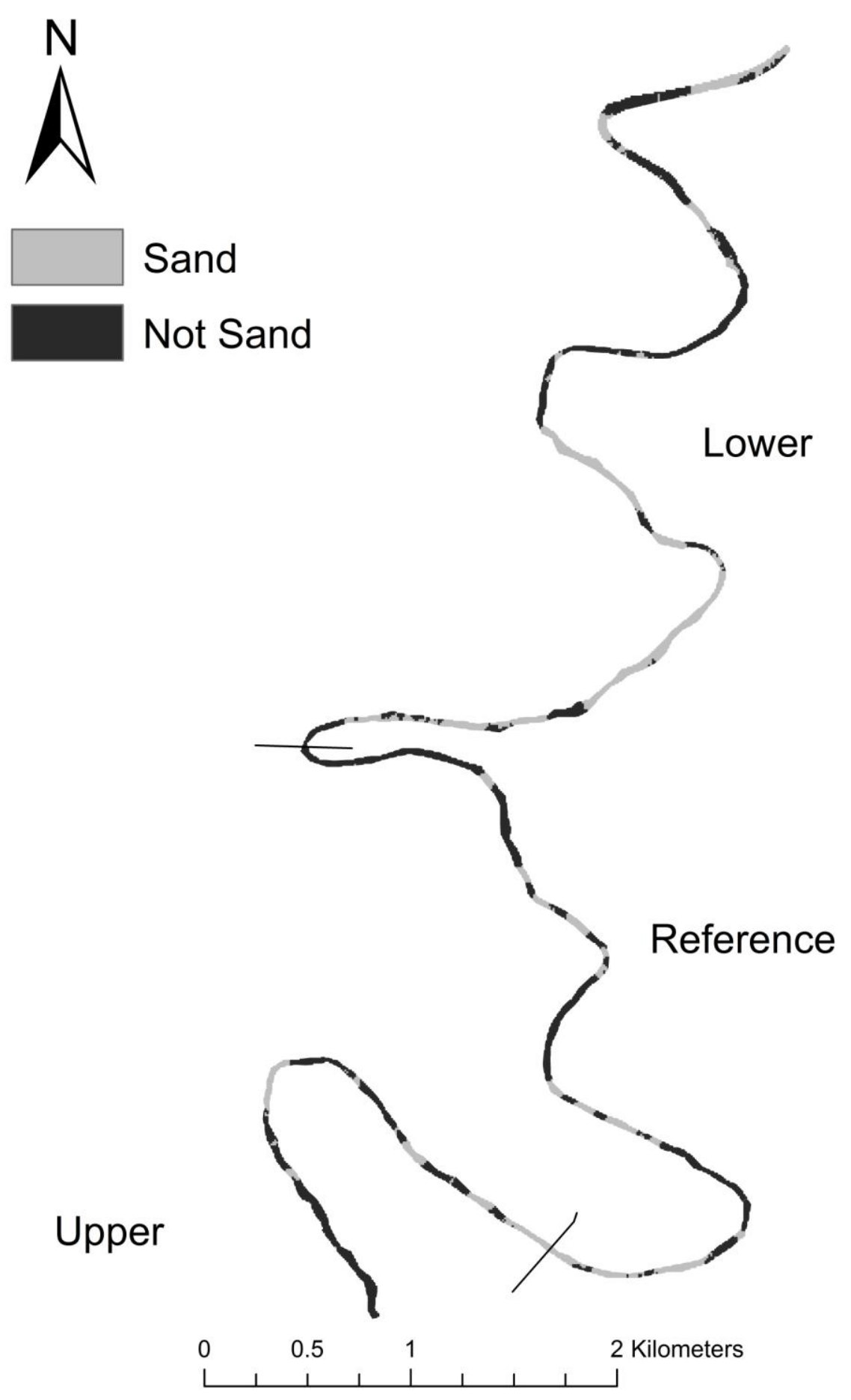

Figure 17. Substrate mapping of the lower $13.7 \mathrm{~km}$ of the Little Coal River in 2009 (gray indicates sand substrate and black indicates gravel, cobble, and boulder substrates). 

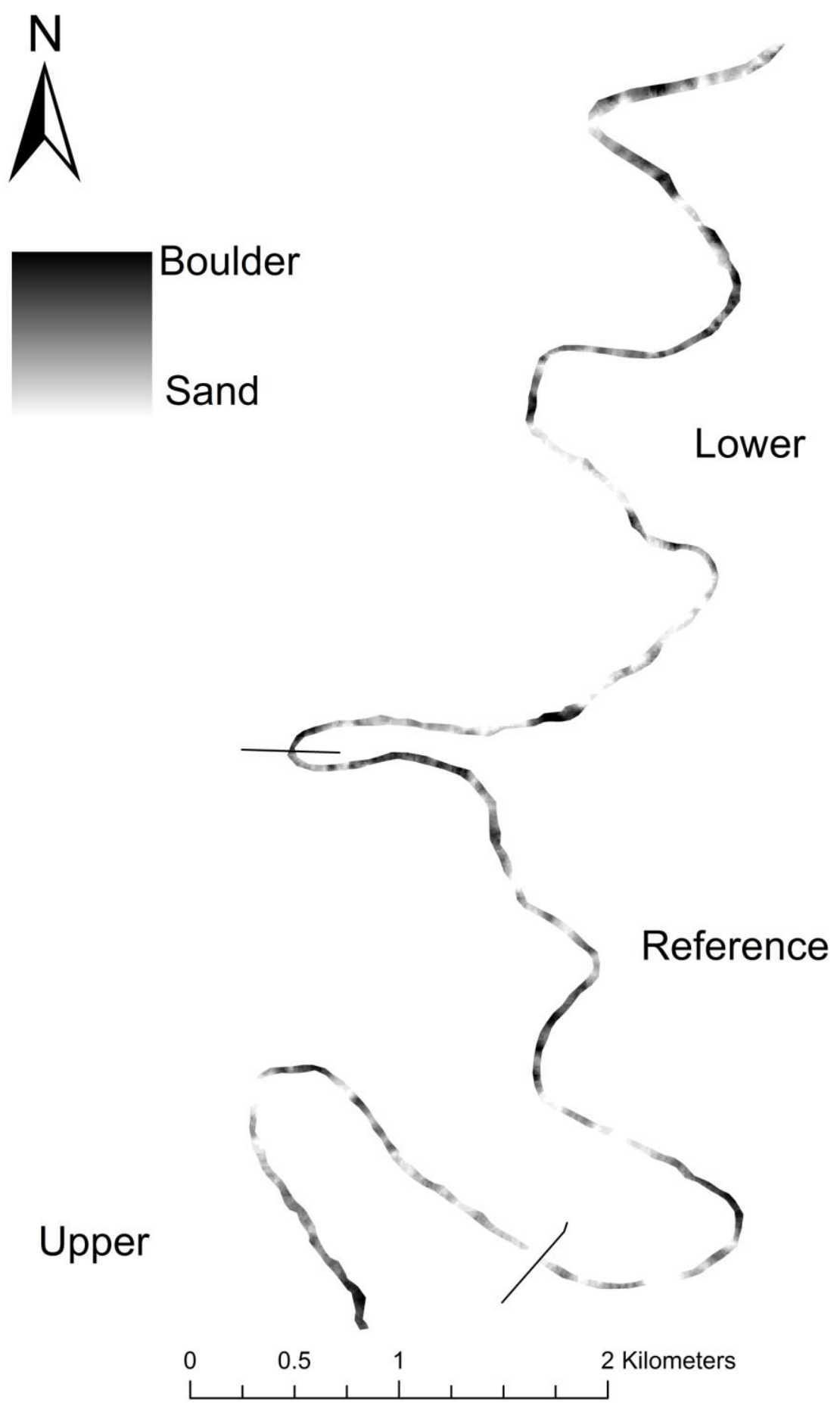

Figure 18. Substrate mapping of the lower $13.7 \mathrm{~km}$ of the Little Coal River in 2010 (lighter colors indicate poor substrate for habitat use and darker colors indicate best substrate type for habitat use). 

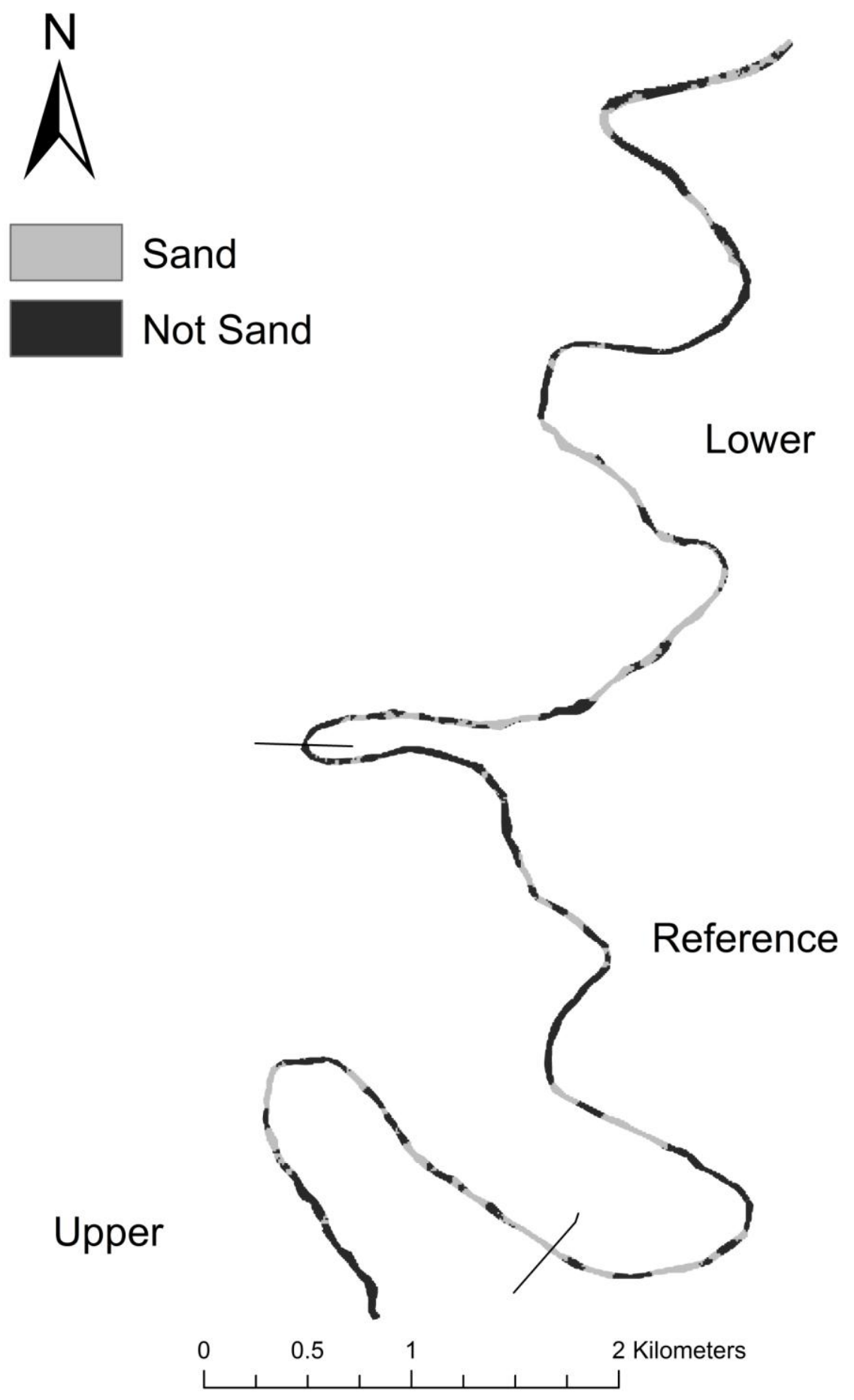

Figure 19. Substrate mapping of the lower $13.7 \mathrm{~km}$ of the Little Coal River in 2010 (gray indicates sand substrate and black indicates gravel, cobble, and boulder substrates). 

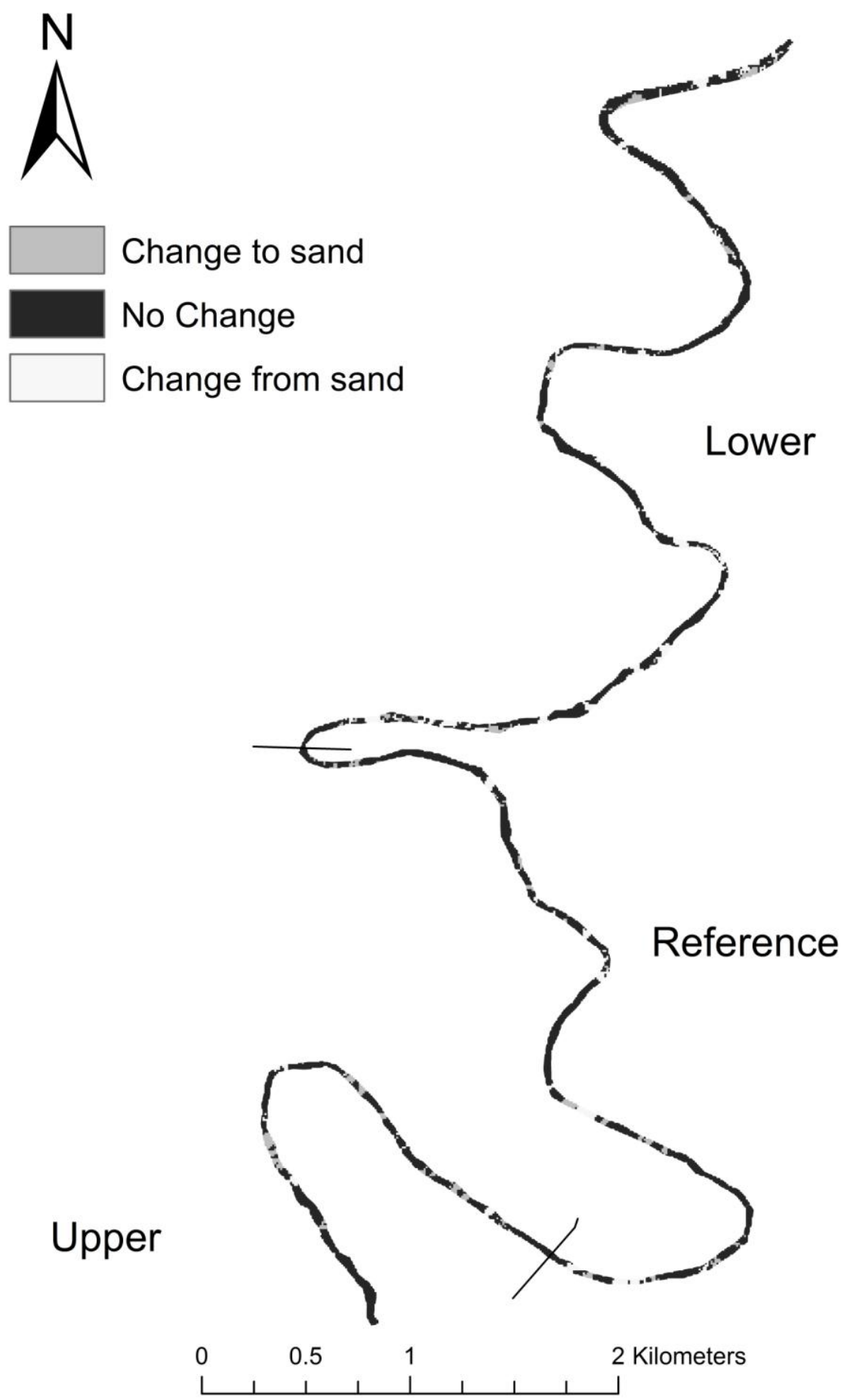

Figure 20. Change in substrate composition of the lower $13.7 \mathrm{~km}$ of the Little Coal River between 2009-2010. 
Table 4. Fishers Exact Test values of substrate type between 2009-2010.

\begin{tabular}{clc}
\hline Reach & $\chi^{2}$ & P-value \\
\hline Entire River & 0.44 & 0.95 \\
Upper & 2.34 & 0.51 \\
Reference & 0.88 & 0.83 \\
Lower & 4.38 & 0.22 \\
\hline
\end{tabular}


Table 5: Pool attributes (in meters) derived from the longitudinal profiles (mean pool depth was calculated from the monument point at the start of each subreach).

\begin{tabular}{lcccccc}
\hline & \multicolumn{2}{c}{ Upper } & \multicolumn{2}{c}{ Reference } & \multicolumn{2}{c}{ Lower } \\
& 2009 & 2010 & 2009 & 2010 & 2009 & 2010 \\
\hline \hline mean pool depth & 4.02 & 4.06 & 3.71 & 3.88 & 2.76 & 3.3 \\
mean pool length & 44 & 45 & 71 & 66 & 53 & 35 \\
mean distance to pool & 123 & 121 & 115 & 121 & 373 & 159 \\
number of pools & 5 & 5 & 5 & 5 & 2 & 5 \\
\hline
\end{tabular}


A)

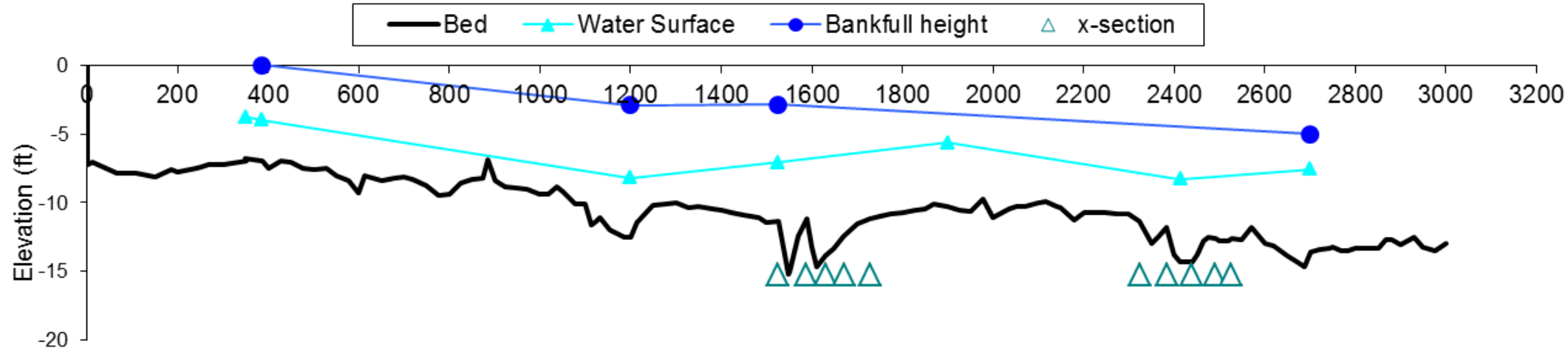

Station or Channel Distance (ft)

B)

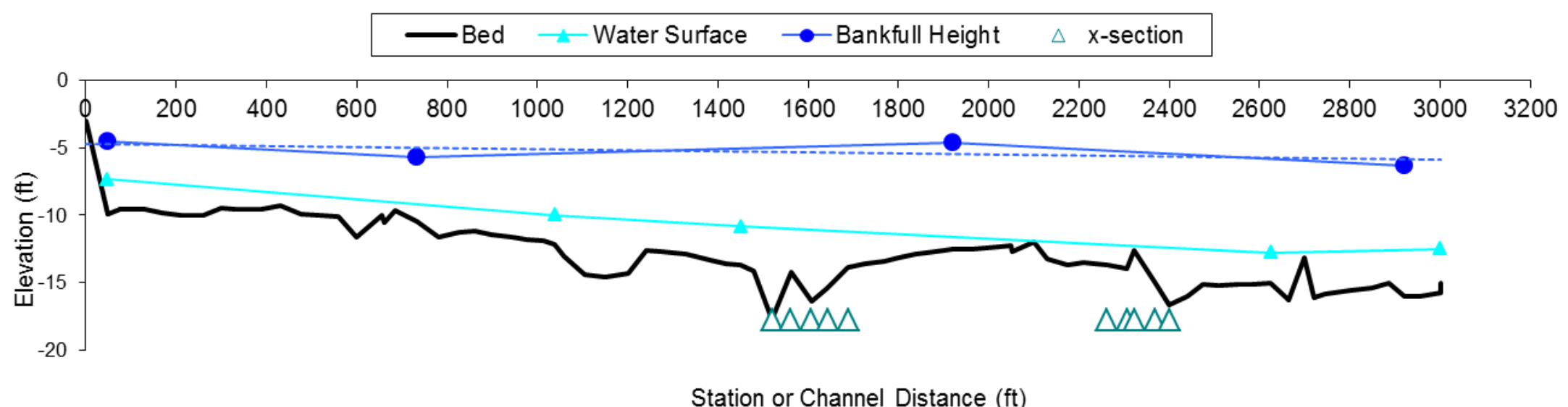

Figure 21. Longitudinal profile of the upper sub-reach in 2009 (A) and 2010 (B) (Open triangles represent areas where cross-sections were performed. 
A)

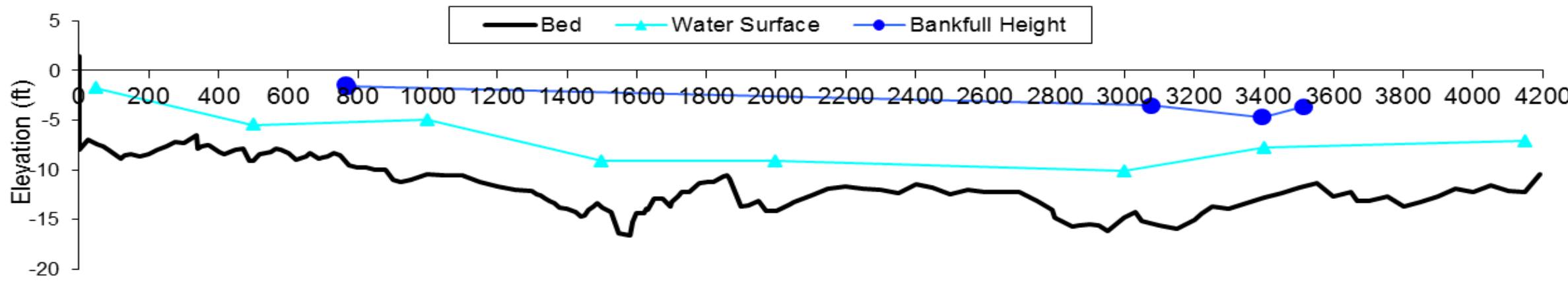

B)

Station or Channel Distance (ft)

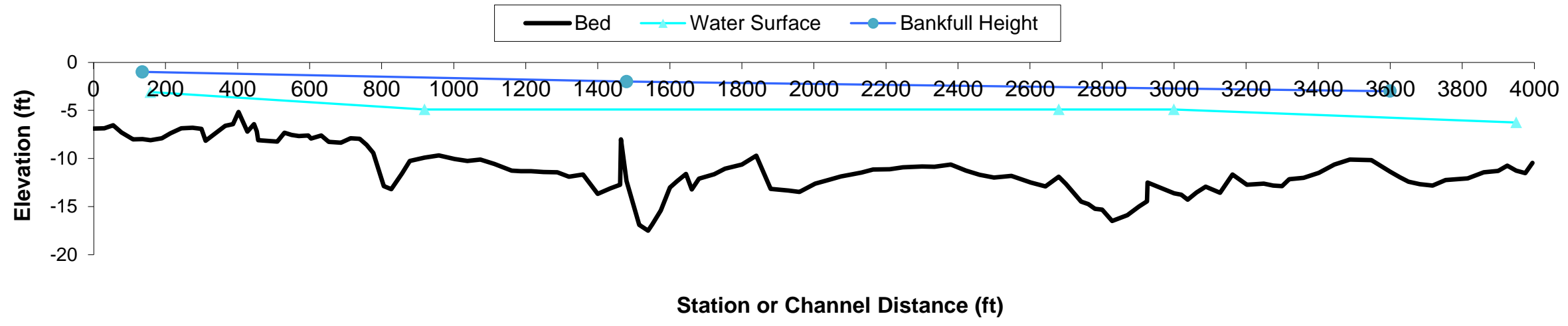

Figure 22. Longitudinal profile of the reference sub-reach in 2009 (A) 2010 (B). 
A)

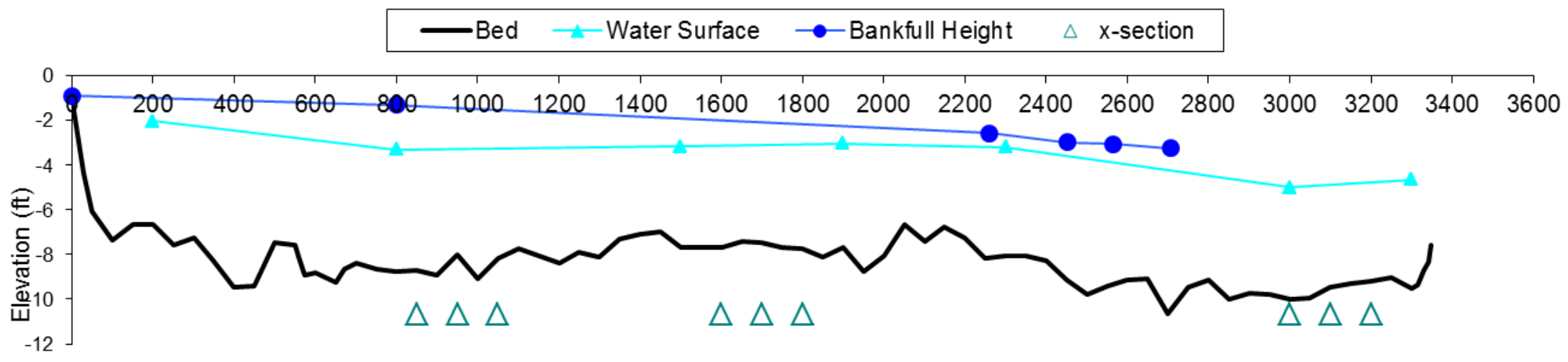

Station or Channel Distance (ft)

B)

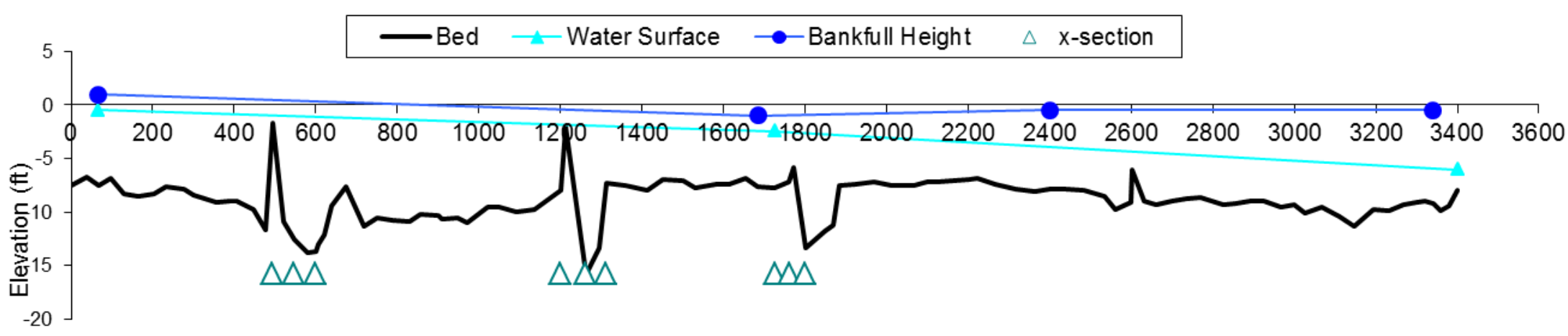

Station or Channel Distance (ft)

Figure 23. Longitudinal profile of the lower sub-reach in 2009 (A) and 2010 (B) (the triangles represent areas where crosssections were performed. 
Table 6. Pair-wise test statistics for comparisons of cross-sections between years (highlighted values indicate significance differences at the $90 \%$ confidence level).

\begin{tabular}{|c|c|c|c|c|c|c|}
\hline & \multirow[t]{2}{*}{$\underline{\text { Variable }}$} & \multicolumn{4}{|r|}{2009} & \multirow{2}{*}{$\frac{\underline{2010}}{\operatorname{Mean}( \pm S E)}$} \\
\hline & & $\begin{array}{c}\text { T- } \\
\text { value }\end{array}$ & Df & $\begin{array}{c}\mathrm{P}- \\
\text { value }\end{array}$ & Mean $( \pm S E)$ & \\
\hline \multirow[t]{5}{*}{ Treatment } & Area & 1.85 & 8 & 0.104 & $1895.42(85.71)$ & $1930.45(85.88)$ \\
\hline & Perimeter & 1.54 & 8 & 0.906 & $297.10(7.23)$ & $297.32(6.68)$ \\
\hline & Entrenchment Ratio & 0.5 & 8 & 0.0001 & $0.1426(0.01)$ & $0.1726(0.01)$ \\
\hline & Bank Height Ratio & 0.996 & 8 & 0.336 & $3.514(0.61)$ & $2.773(0.42)$ \\
\hline & Peri:Area Ratio & -1.24 & 8 & 0.12 & $0.1581(0.004)$ & (0.1555 (0.01) \\
\hline \multirow[t]{5}{*}{ Control } & Area & -1.83 & 11 & 0.18 & $2514.29(75.53)$ & 2416.94 (115.3) \\
\hline & Perimeter & -0.12 & 11 & 0.15 & 373.76 (11.79) & $369.22(11.92)$ \\
\hline & Entrenchment Ratio & -3.08 & 11 & 0.624 & $0.1303(0.007)$ & $0.129(0.008)$ \\
\hline & Bank Height Ratio & -0.303 & 11 & 0.764 & $2.326(0.09)$ & $2.369(0.11)$ \\
\hline & Peri:Area Ratio & 1.74 & 11 & 0.242 & $0.1015(0.03)$ & $0.1076(0.03)$ \\
\hline
\end{tabular}


Table 7. Global cross section results from $2 \times 3$ factorial analyses of variance (ANOVA) (highlighted values indicate results that are significant at the $90 \%$ confidence level).

\begin{tabular}{|c|c|c|c|}
\hline Variable & Df & F-Value & P-Value \\
\hline \multicolumn{4}{|l|}{ Area } \\
\hline Reach & 2 & 55.5023 & 0.0001 \\
\hline Year & 1 & 0.3838 & 0.5395 \\
\hline Reach x Year & 2 & 1.3464 & 0.273 \\
\hline \multicolumn{4}{|l|}{ Perimeter } \\
\hline Reach & 2 & 132.7423 & 0.0001 \\
\hline Year & 1 & 0.1961 & 0.6605 \\
\hline Reach x Year & 2 & 0.0974 & 0.9075 \\
\hline \multicolumn{4}{|c|}{ Perimeter:Area Ratio } \\
\hline Reach & 2 & 8.1755 & 0.0011 \\
\hline Year & 1 & 0.0216 & 0.88386 \\
\hline Reach x Year & 2 & 0.1959 & 0.82295 \\
\hline \multicolumn{4}{|l|}{$\mathrm{CV}$} \\
\hline Reach & 2 & 3.7021 & 0.0345 \\
\hline Year & 1 & 7.4021 & 0.0099 \\
\hline Reach x Year & 2 & 2.8107 & 0.07341 \\
\hline \multicolumn{4}{|l|}{ Bank Height Ratio } \\
\hline Reach & 2 & 3.055 & 0.0597 \\
\hline Year & 1 & 0.7735 & 0.3849 \\
\hline Reach x Year & 2 & 0.6849 & 0.5106 \\
\hline \multicolumn{4}{|c|}{ Entrenchment Ratio } \\
\hline Reach & 2 & 4.5489 & 0.0173 \\
\hline Year & 1 & 1.508 & 0.22742 \\
\hline Reach x Year & 2 & 1.2392 & 0.30166 \\
\hline
\end{tabular}


Table 8. Tukey's pairwise comparisons results of cross sections (only significant interactions are listed).

\begin{tabular}{|c|c|}
\hline Variable & P-adj \\
\hline \multicolumn{2}{|l|}{ Area } \\
\hline Upper 2009-Lower 2009 & 0.0001 \\
\hline Upper 2010-Lower 2009 & 0.0001 \\
\hline Upper 2010-Referenece 2009 & 0.0001 \\
\hline Lower 2010-Upper 2009 & 0.0001 \\
\hline Reference 2010-Upper 2009 & 0.0001 \\
\hline Upper 2009-Reference 2009 & 0.01 \\
\hline \multicolumn{2}{|l|}{ Perimeter } \\
\hline Upper 2009-Lower 2009 & 0.0001 \\
\hline Upper 2010-Lower 2009 & 0.0001 \\
\hline Upper 2009-Reference 2009 & 0.0001 \\
\hline Upper 2010-Reference 2009 & 0.0001 \\
\hline Lower 2010-Upper 2009 & 0.0001 \\
\hline Reference 2010-Upper 2009 & 0.0001 \\
\hline Upper 2010-Lower 2010 & 0.0001 \\
\hline Upper 2010-Reference 2010 & 0.0001 \\
\hline \multicolumn{2}{|l|}{ Perimeter Area Ratio } \\
\hline Upper 2009-Lower 2009 & 0.091 \\
\hline Upper 2010-Lower 2009 & 0.0966 \\
\hline \multicolumn{2}{|l|}{ CV } \\
\hline Upper 2010-Lower 2009 & 0.0028 \\
\hline Upper 2010-Upper 2009 & 0.0466 \\
\hline Upper 2010-Reference 2010 & 0.0999 \\
\hline \multicolumn{2}{|l|}{ Entrenchment Ratio } \\
\hline Lower 2010-Upper 2009 & 0.04 \\
\hline Upper 2010-Lower 2010 & 0.031 \\
\hline
\end{tabular}


A)

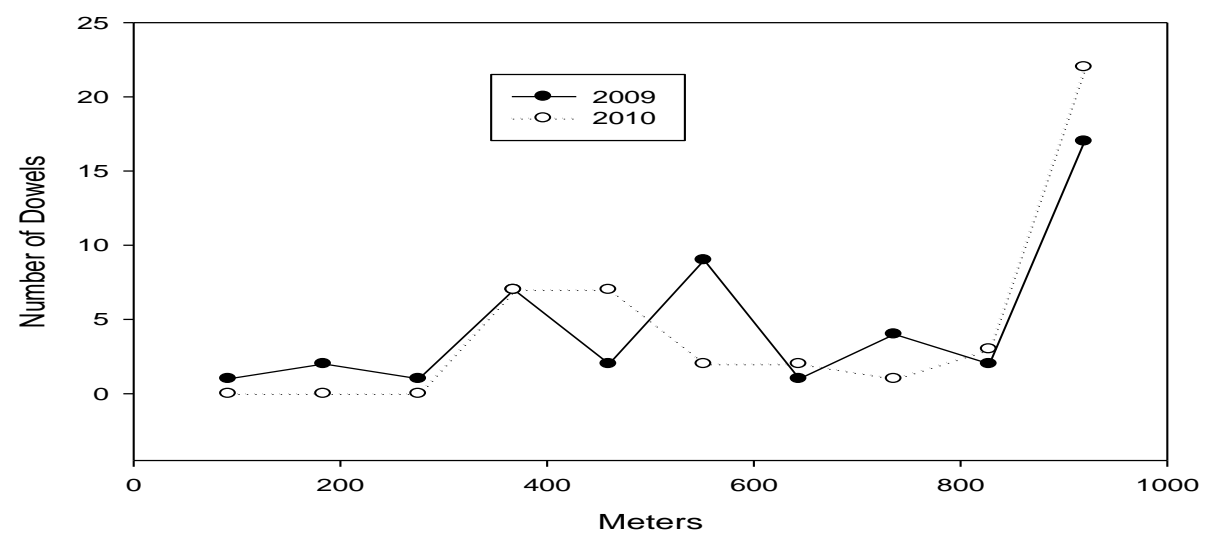

B)

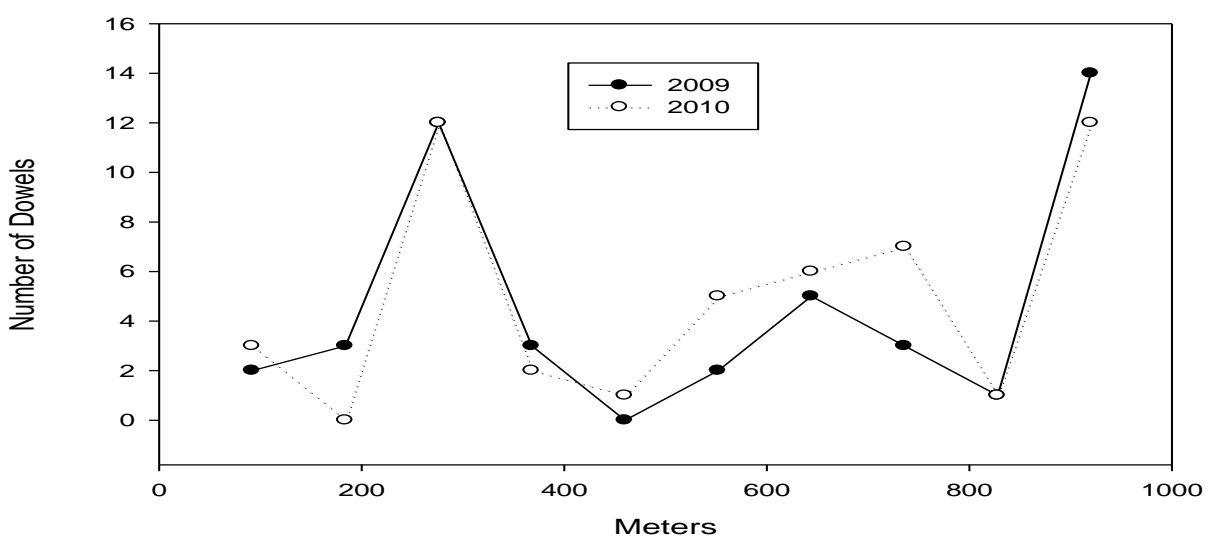

C)

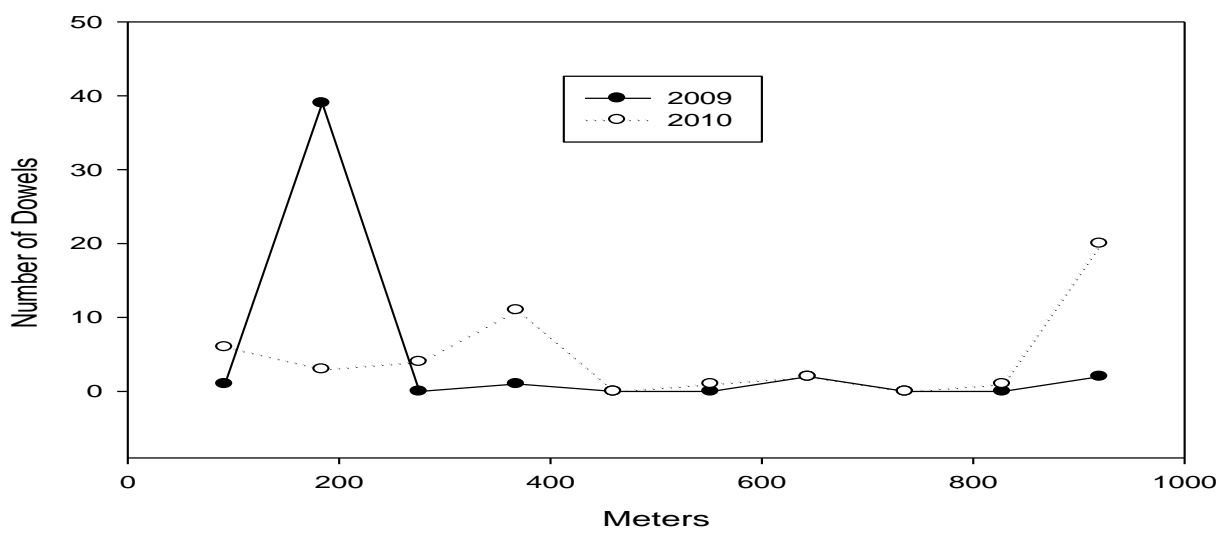

Figure 24. Dowel rod retention in each sub-reach A) Upper B) Reference and C) Lower with respect to distance traveled (at 920 meters dowel rods had passed through the entire reach unretained). 
Table 9: Retained and not retained dowel rods in each sub-reach and year.

\begin{tabular}{ccccccc}
\hline & \multicolumn{2}{c}{ Upper } & \multicolumn{2}{c}{ Reference } & \multicolumn{2}{c}{ Lower } \\
& 2009 & 2010 & 2009 & 2010 & 2009 & 2010 \\
\hline \hline Retained & 31 & 22 & 31 & 37 & 45 & 30 \\
Not Retained & 17 & 22 & 14 & 12 & 2 & 20 \\
\hline
\end{tabular}


Table 10: Results from 3×2x2 factorial analysis of variance (ANOVA) on our macroinvertebrate community, highlighted values indicate results that are significant at the $90 \%$ confidence level. $\mathrm{mWVSCl}$ represent the Modified Stream Condition Index scores; \%EPT is the percent of ephemeroptera, plecoptera, and tricoptera; and total abundance is the abundance of all macroinvertebrates.

\begin{tabular}{|c|c|c|c|c|}
\hline Variable & & Df & F-Value & P-Value \\
\hline \multicolumn{5}{|l|}{$m \mathrm{WVSCl}$} \\
\hline & Substrate & 1 & 495.17 & 0.0001 \\
\hline & Season & 1 & 56.11 & 0.0001 \\
\hline & Reach & 2 & 1.19 & 0.401 \\
\hline & Substrate $x$ Season & 1 & 0.94 & 0.331 \\
\hline & Substrate $\mathrm{x}$ Reach & 2 & 0.09 & 0.726 \\
\hline & Season x Reach & 2 & 0.45 & 0.483 \\
\hline & Substrate $\times$ Season $\times$ Reach & 2 & 0.33 & 0.671 \\
\hline \multicolumn{5}{|l|}{$\%$ EPT } \\
\hline & Substrate & 1 & 303.18 & 0.0001 \\
\hline & Season & 1 & 81.02 & 0.0001 \\
\hline & Reach & 2 & 1.52 & 0.152 \\
\hline & Substrate $x$ Season & 1 & 17.20 & 0.0001 \\
\hline & Substrate $\times$ Reach & 2 & 0.53 & 0.304 \\
\hline & Season x Reach & 2 & 0.03 & 0.789 \\
\hline & Substrate $\times$ Season $\times$ Reach & 2 & 0.09 & 0.979 \\
\hline \multicolumn{5}{|c|}{ Total Abundance } \\
\hline & Substrate & 1 & 256.38 & 0.0001 \\
\hline & Season & 1 & 143.52 & 0.0001 \\
\hline & Reach & 2 & 0.88 & 0.328 \\
\hline & Substrate $x$ Season & 1 & 121.23 & 0.0001 \\
\hline & Substrate x Reach & 2 & 1.56 & 0.235 \\
\hline & Season x Reach & 2 & 0.24 & 0.625 \\
\hline & Substrate $\mathrm{x}$ Season $\mathrm{x}$ Reach & 2 & 0.40 & 0.826 \\
\hline
\end{tabular}


Table 11. Tukey's pairwise comparisons results of macroinvertebrate community structure (highlighted values indicate results that are significant at the $90 \%$ confidence level). SS represent sand/silt samples and CG represents cobble/gravel samples.

\begin{tabular}{lcc}
\hline & $\begin{array}{c}\text { Total Abundance } \\
\text { P adj }\end{array}$ & $\begin{array}{c}\text { \%EPT } \\
\text { P adj }\end{array}$ \\
\hline Spring SS-Spring CG & $\mathbf{0 . 0 0 3}$ & $\mathbf{0 . 0 0 0 1}$ \\
Fall CG-Spring CG & $\mathbf{0 . 0 0 0 1}$ & $\mathbf{0 . 0 0 0 1}$ \\
Fall SS-Spring CG & $\mathbf{0 . 0 2 6}$ & $\mathbf{0 . 0 0 0 1}$ \\
Fall CG-Spring SS & $\mathbf{0 . 0 0 0 1}$ & $\mathbf{0 . 0 0 0 1}$ \\
Spring SS-Fall SS & 0.8986 & $\mathbf{0 . 0 0 4}$ \\
Fall SS-Fall CG & $\mathbf{0 . 0 0 0 1}$ & $\mathbf{0 . 0 0 0 1}$ \\
\hline
\end{tabular}




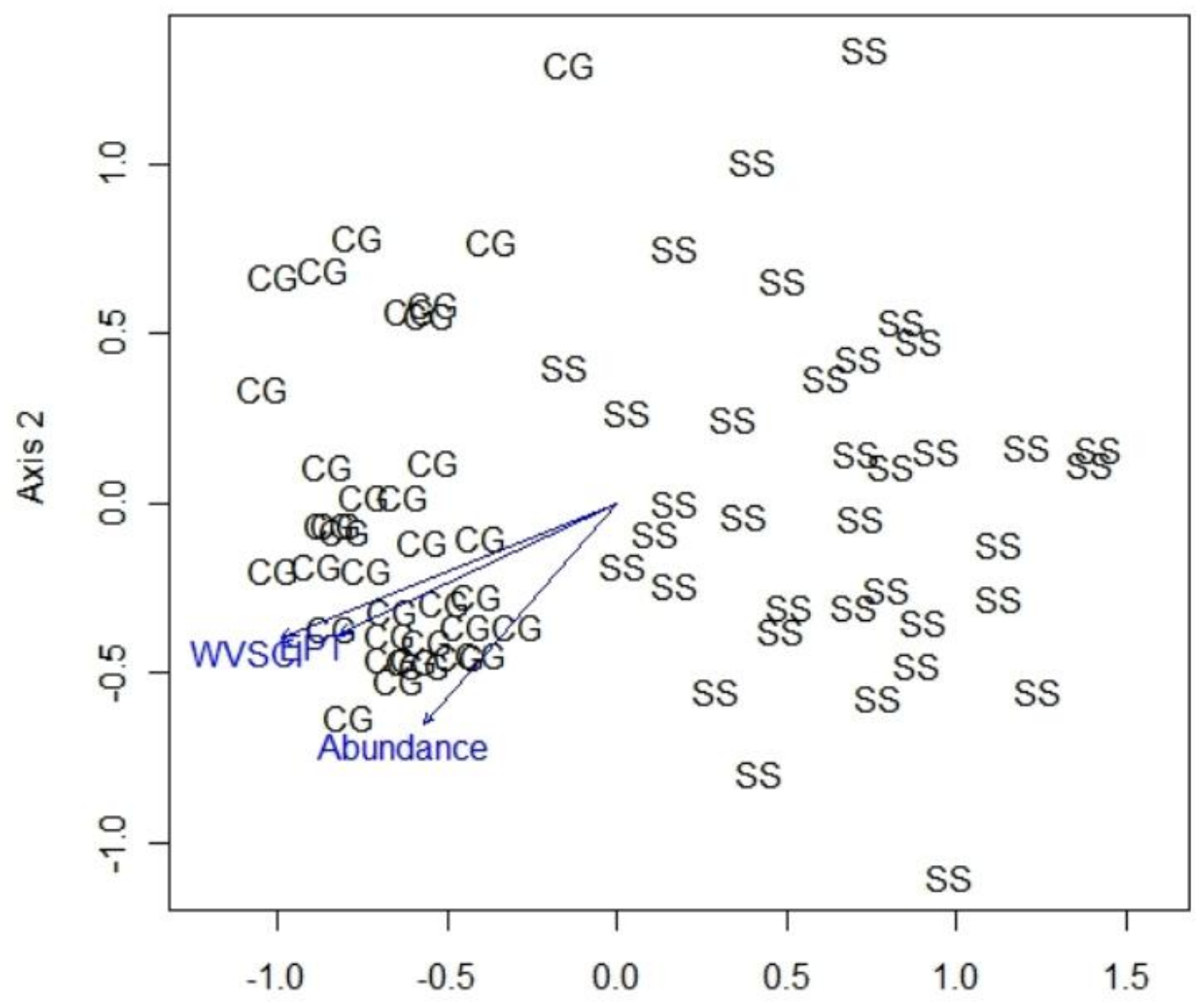

Axis 1

Figure 25. A NMDS plot of genus level invertebrate community structure based on substrate type $(C G=$ cobble and gravel, $S S=$ sand and silt substrate, WVSCI $=$ West Virginia Stream Condition Index, EPT = \% emphemeroptera, plecoptera and trichoptera, and Abundance $=$ total number of macroinvertabrates). 


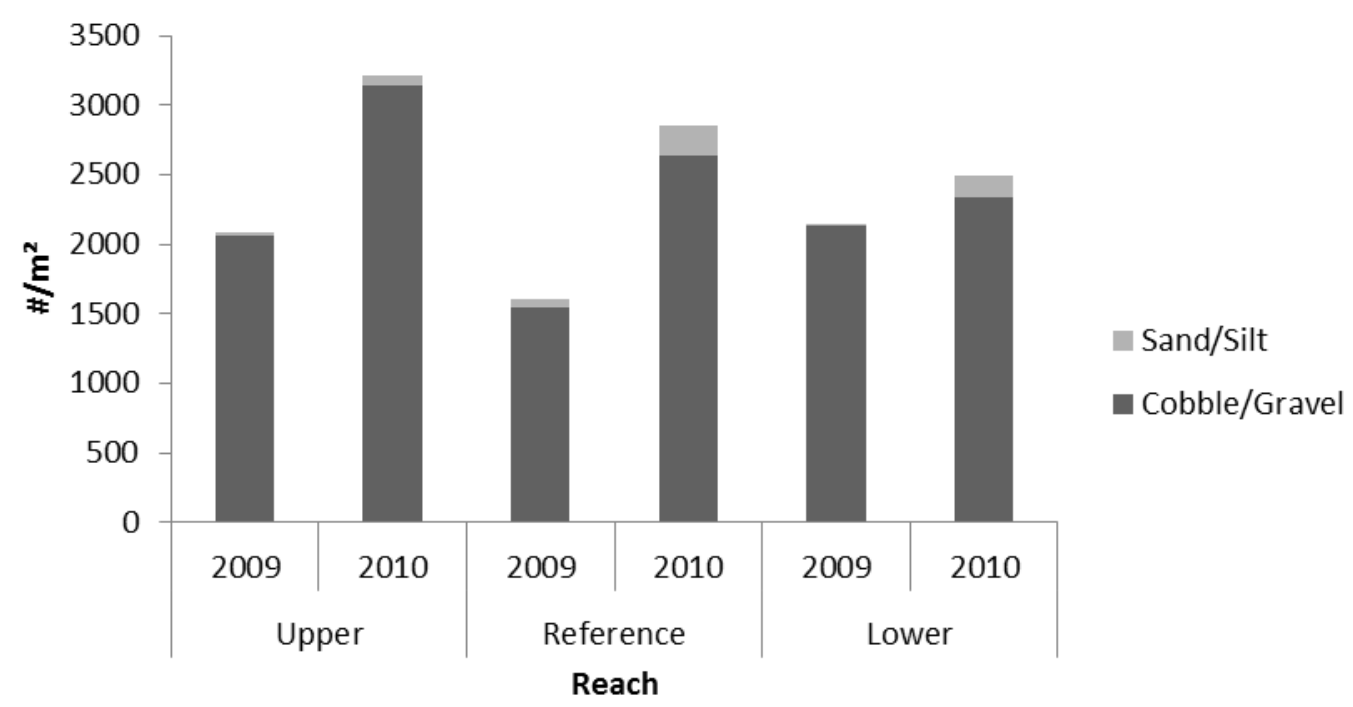

Figure 26. Macroinvertabrate abundance by year, reach, and substrate. 


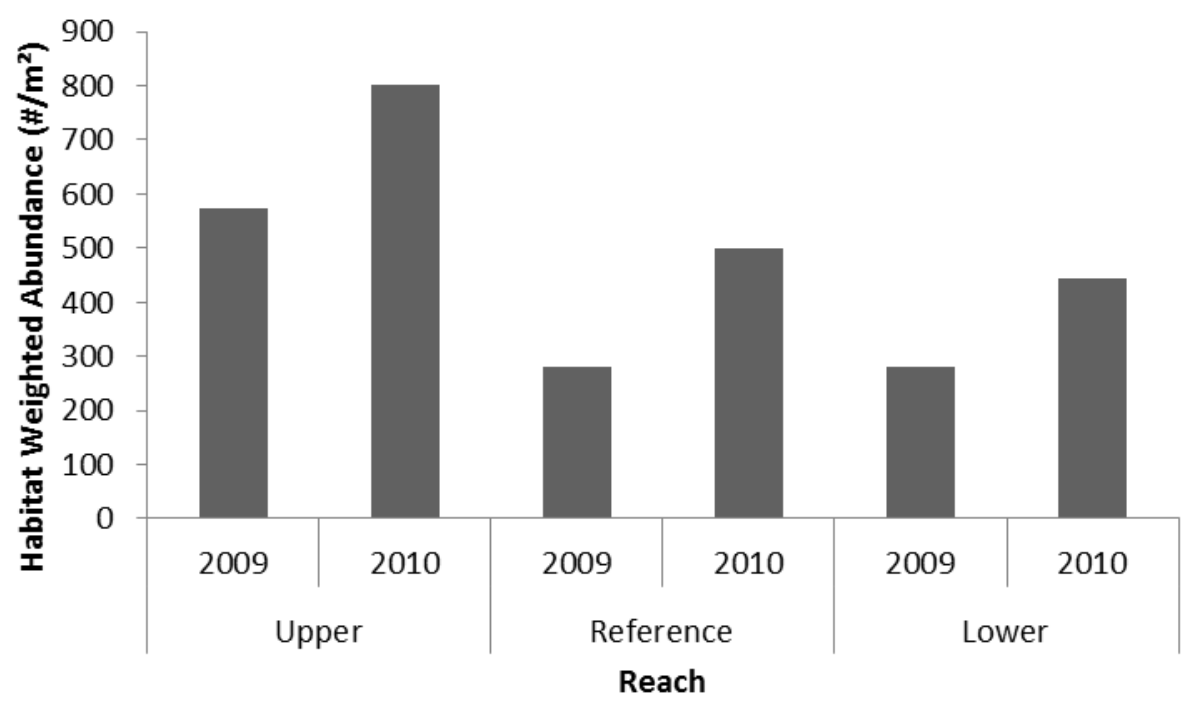

Figure 27. Macroinvertebrate habitat weighted abundance by reach and year. 
Table 12. Fish community structure by year and sub-reach. Percent represents the percentage of the population that comprising that species. Mean \# per $500 \mathrm{~s}$ is the number of fish collected in 500 of the total 2500 seconds.

\begin{tabular}{|c|c|c|c|c|c|c|c|c|c|c|c|c|}
\hline \multirow{3}{*}{ Species } & \multicolumn{4}{|c|}{ Upper } & \multicolumn{4}{|c|}{ Reference } & \multicolumn{4}{|c|}{ Lower } \\
\hline & \multicolumn{2}{|c|}{2009} & \multicolumn{2}{|c|}{2010} & \multicolumn{2}{|c|}{2009} & \multicolumn{2}{|c|}{2010} & \multicolumn{2}{|c|}{2009} & \multicolumn{2}{|c|}{2010} \\
\hline & Percent\% & $\begin{array}{c}\text { Mean \# per } \\
500 \mathrm{~s}\end{array}$ & Percent\% & $\begin{array}{c}\text { Mean \# per } \\
500 \mathrm{~s} \\
\end{array}$ & Percent\% & $\begin{array}{c}\text { Mean \# per } \\
500 \mathrm{~s}\end{array}$ & Percent\% & $\begin{array}{c}\text { Mean \# per } \\
500 \mathrm{~s} \\
\end{array}$ & Percent\% & $\begin{array}{c}\text { Mean \# per } \\
500 \mathrm{~s}\end{array}$ & Percent\% & $\begin{array}{c}\text { Mean \# per } \\
500 \mathrm{~s}\end{array}$ \\
\hline Rock Bass & 1.18 & 0.2 & 3.33 & 0.2 & 3.65 & 1 & 1.64 & 0.6 & 3.45 & 0.4 & 2.27 & 0.2 \\
\hline \multicolumn{13}{|c|}{ Ambloplties rupestris } \\
\hline Freshwater Drum & . & $\cdot$ & $\cdot$ & . & . & $\cdot$ & $\cdot$ & . & 1.72 & 0.2 & 2.27 & 0.2 \\
\hline \multicolumn{13}{|c|}{ Aplodinotus grunniens } \\
\hline Common Carp & . & . & 3.33 & 0.2 & 1.46 & 0.4 & 0.55 & 0.2 & . & . & & . \\
\hline \multicolumn{13}{|c|}{ Cyprinus carpio } \\
\hline Central Stoneroller & . & $\cdot$ & $\cdot$ & $\cdot$ & 37.96 & 10.4 & 55.19 & 20.2 & $\cdot$ & $\cdot$ & & $\cdot$ \\
\hline \multicolumn{13}{|c|}{ Campostoma anomalum } \\
\hline Spotfin Shiner & 2.35 & 0.4 & 10 & 0.6 & 1.46 & 0.4 & 0.55 & 0.2 & $\cdot$ & . & & $\cdot$ \\
\hline \multicolumn{13}{|c|}{ Cyprinella spiloptera } \\
\hline \multicolumn{13}{|c|}{ Dorosoma cepedianum } \\
\hline Greenside Darter & 1.18 & 0.2 & $\cdot$ & . & 2.92 & 0.8 & 5.46 & 2 & $\cdot$ & . & & . \\
\hline \multicolumn{13}{|c|}{ Etheostoma blennioides } \\
\hline Streamline Chub & . & $\cdot$ & $\cdot$ & . & $\cdot$ & $\cdot$ & $\cdot$ & . & . & . & 2.27 & 0.2 \\
\hline \multicolumn{13}{|c|}{ Erimystax dissimilis } \\
\hline Rinabow Dater & . & . & . & . & 1.46 & 0.4 & 3.28 & 1.2 & . & . & & . \\
\hline \multicolumn{13}{|c|}{ Etheostoma caeruleum } \\
\hline Variegate Darter & $\cdot$ & $\cdot$ & $\cdot$ & $\cdot$ & 2.19 & 0.6 & 4.92 & 1.8 & $\cdot$ & . & & . \\
\hline \multicolumn{13}{|c|}{ Etheostoma variatum } \\
\hline Banded Darter & 2.35 & 0.4 & . & . & 9.49 & 2.6 & 2.73 & 1 & . & . & & . \\
\hline
\end{tabular}


Table 12. Continued

\section{Bigeye Chub \\ Hybopsis amblops}

Northern Hog Sucker

Hypentelium nigricans

Longnose Gar

Lepisosteus osseus

\section{Ohio Lamprey}

Ichthyomyzon bdellium

Smallmouth Buffalo Ictiobus bubalus

Channel Catfish

$$
\text { Ictalurus punctatus }
$$

Least Brook Lamprey

$$
\text { Lampetra aepyptera }
$$

Green Sunfish

Lepomis cyanellus

Longear Sunfish

Lepomis megalotis

Striped Shiner

$$
\text { Luxilus chrysocephalus }
$$

Smallmouth Bass

Micropterus dolomieu

Spotted Bass

Micropterus punctulatus
23.53

4

11.76

2

10

0.6

15.33

4.2

36.21

4.2

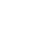

1

2.19

0.8

1.72

0.2

9.09

0.8

0.55

0.2

3.33

0.2

1.46

0.4

2.73

0.2
0.73

1.64

3.33

0.2

2.35

0.4

2.92

0.8

0.55

0.2

33

0.2

0.55

0.2

1.72

0.2

9.09

0.8

1.09

0.4

11.76

6.67

0.4

2.92

0.8

0.55

0.2

17.24

0.55

0.2

5.17

0.6

4.55

0.2

$\begin{array}{llll}1.18 & 0.2 & 6.67 & 0.4\end{array}$

0.4

(1)

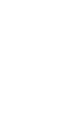




\section{Table12.Continued}

River Redhorse

Moxostoma carinatum

Golden Redhorse

Moxostoma erythrurum

Shorthead Redhorse

14.12

2.35

0.4

3.33

Moxostoma macrolepidotum

Dusky Shiner

Notropis cummingsae

Sand Shiner

Notropis stramineus

Silver Shiner

Notropis photogenis

\section{Rosyface Shiner}

Notropis rubellus

Logperch

Percina caprodes

Blackside Dater

Percina maculata

Bluntnose Minnow

Pimephales notatus

Flathead Catfish

Pylodictis olivaris

Sauger

1.18

3.33

1.18

0.2

3.33

1.18

0.2

3.33
1.46

0.4

$1.2 \quad 4.38$

0.2

$1.2 \quad 1.09$

0.4

10.34

1.2

$\begin{array}{ll}0.55 & 0.2\end{array}$

0.73

0.2

4.92

1.8

0.2

0.2

0.73

0.2

1.64

0.6

1.72

0.2

34.09

0.55

0.2

3.45

0.4

0.2

6.9

0.8

.


Table 13. Similarity analyses based on fish community (highlighted values indicate reaches that are significantly dissimilar at the $90 \%$ confidence level).

\begin{tabular}{lcc}
\hline \multicolumn{1}{c}{ Reach } & R statistic & P-value \\
\hline 2009-2010 & 0.194 & $\mathbf{0 . 0 3 5}$ \\
2009 Across Reaches & -0.036 & 0.640 \\
2010 Across Reaches & 0.116 & 0.147 \\
Upper 2009-Upper 2010 & 0.166 & 0.126 \\
Upper 2009-Reference 2010 & 0.001 & 0.461 \\
Upper2009-Lower 2010 & 0.296 & $\mathbf{0 . 0 2 2}$ \\
Reference 2009-Upper 2010 & 0.172 & 0.150 \\
Reference 2009-Reference 2010 & 0.016 & 0.450 \\
Reference 2009-Lower 2010 & 0.238 & $\mathbf{0 . 0 9 7}$ \\
Lower 2009-Upper 2010 & 0.226 & $\mathbf{0 . 0 5 6}$ \\
Lower 2009-Reference 2010 & 0.100 & 0.257 \\
Lower 2009-Lower 2010 & 0.332 & $\mathbf{0 . 0 4 4}$ \\
\hline
\end{tabular}




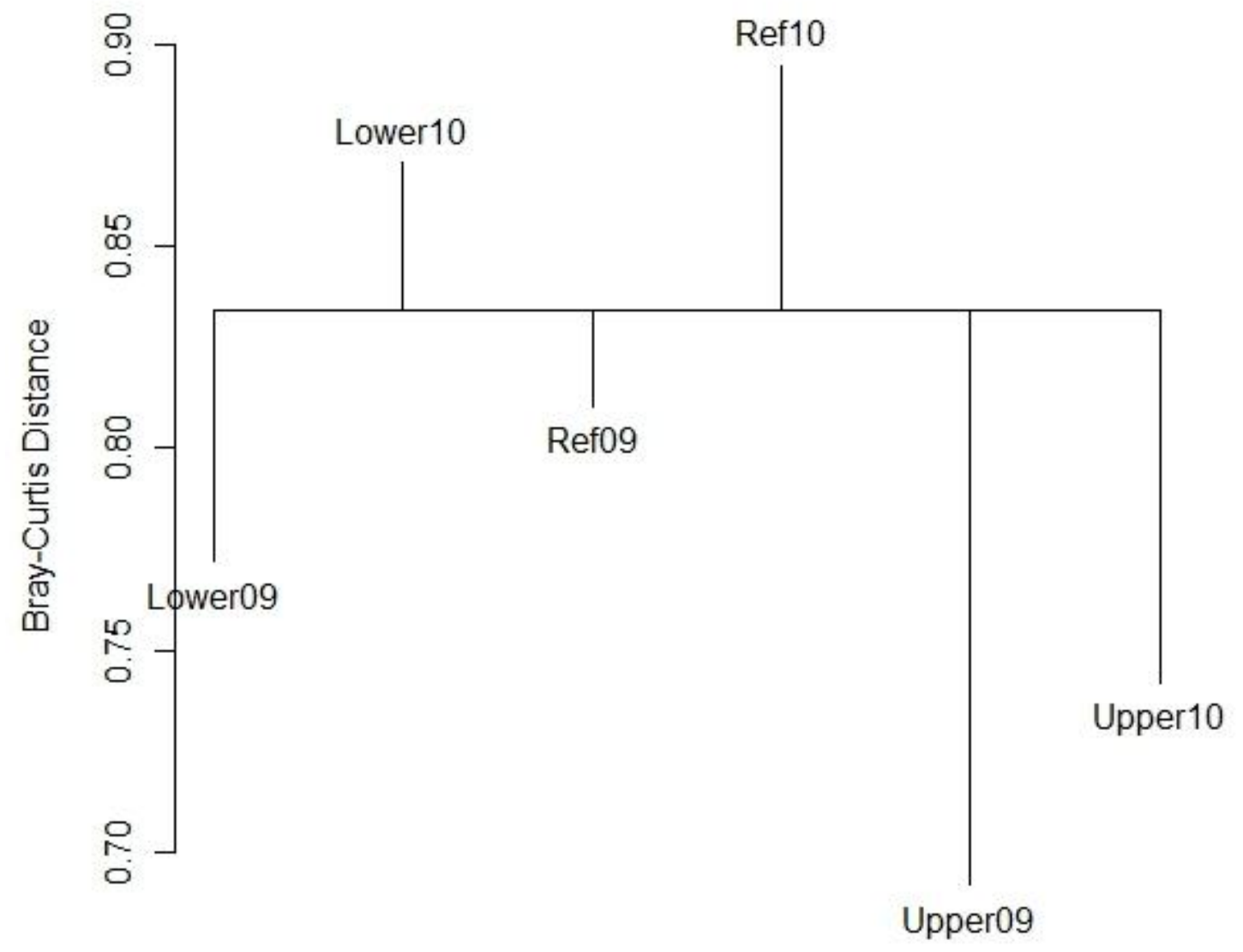

Figure 28. Mean similarity dendrogram for fish assemblage. The horizontal line is the overall mean between group similarity and the vertical lines are the withingroup similarity for each reach and year. 


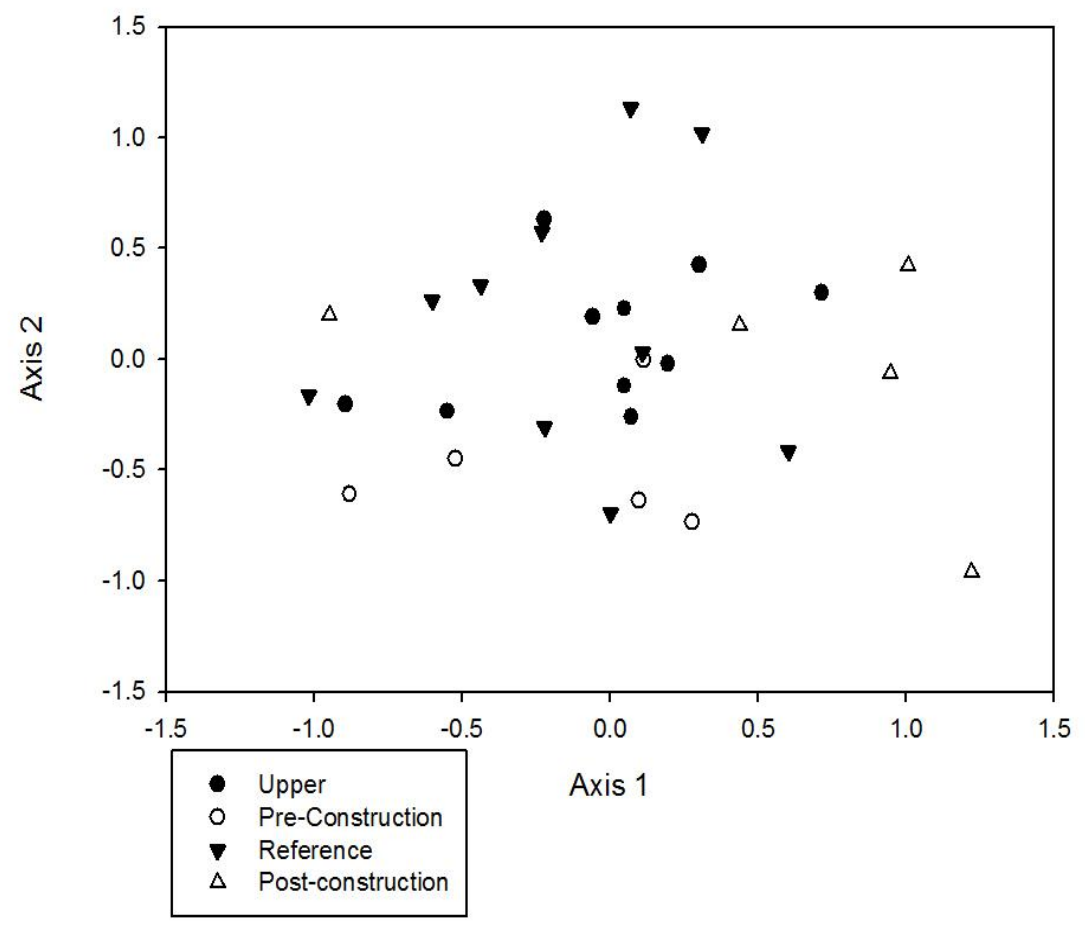

Figure 29. Non-Metric Multidimensional Scaling (NMDS) ordination of fish community similarity matrix (each symbol represents a single site and separation of sites is based on Bray-Curtis distances). 


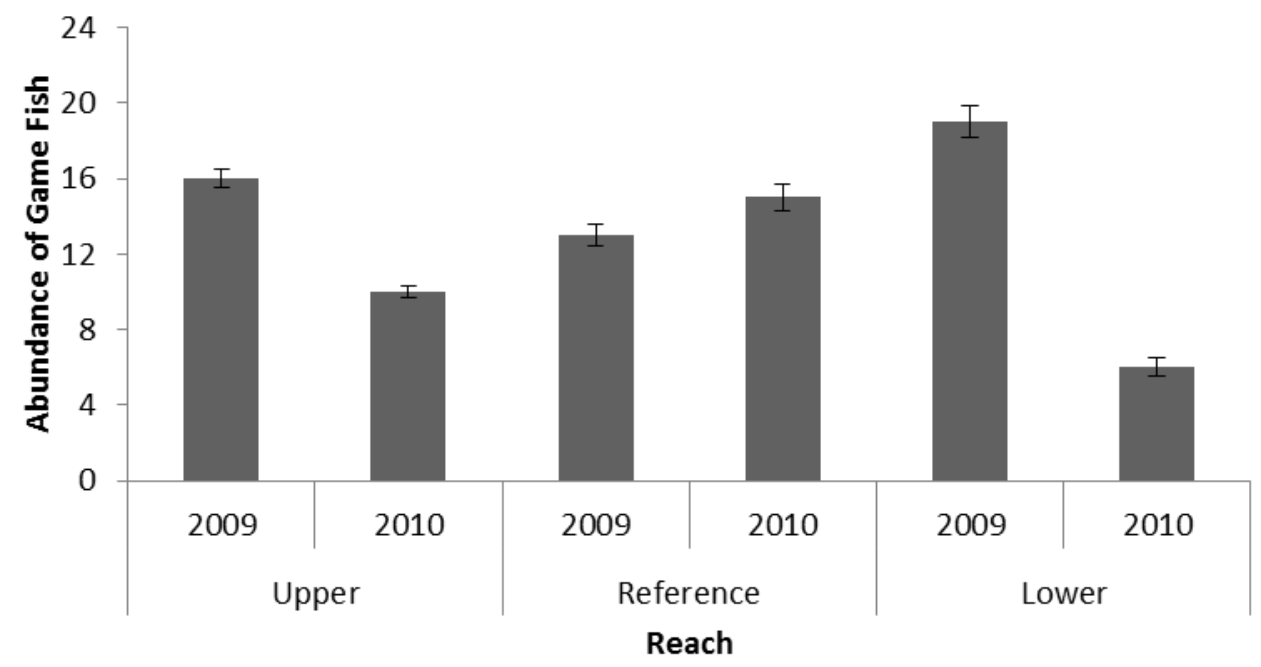

Figure 30. Game fish abundance collected by year and reach with standard error bars. 


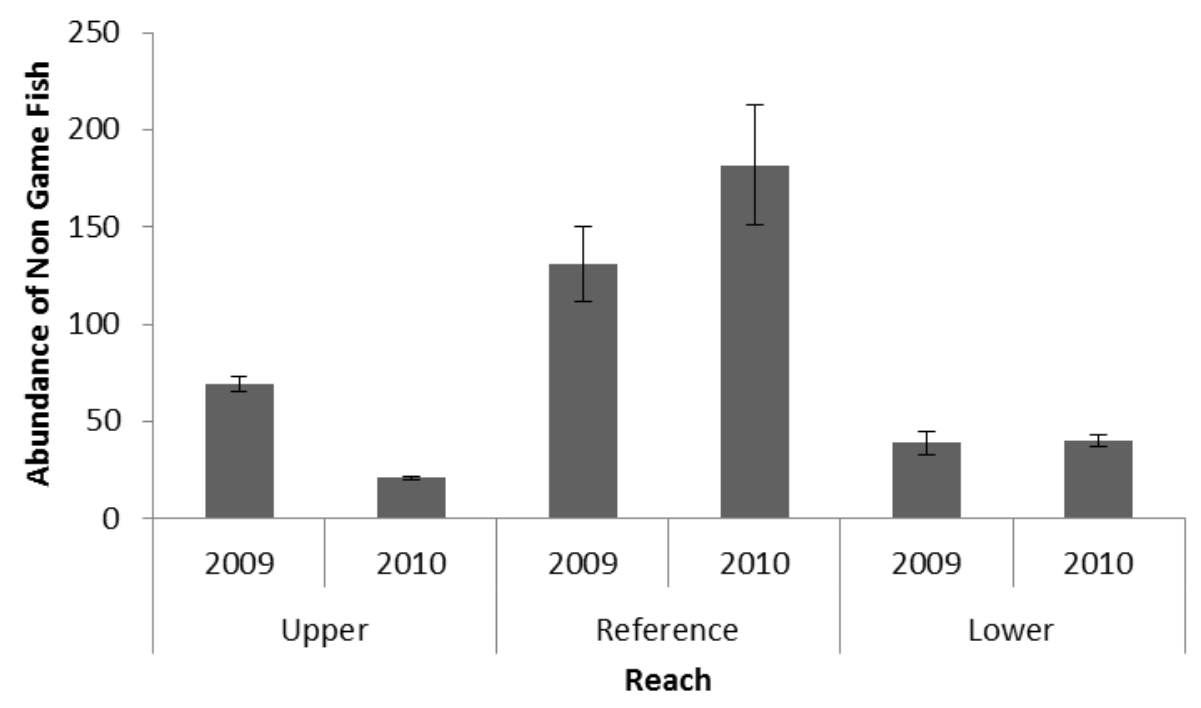

Figure 31. Non game fish abundance collected by year and reach with standard error bars. 


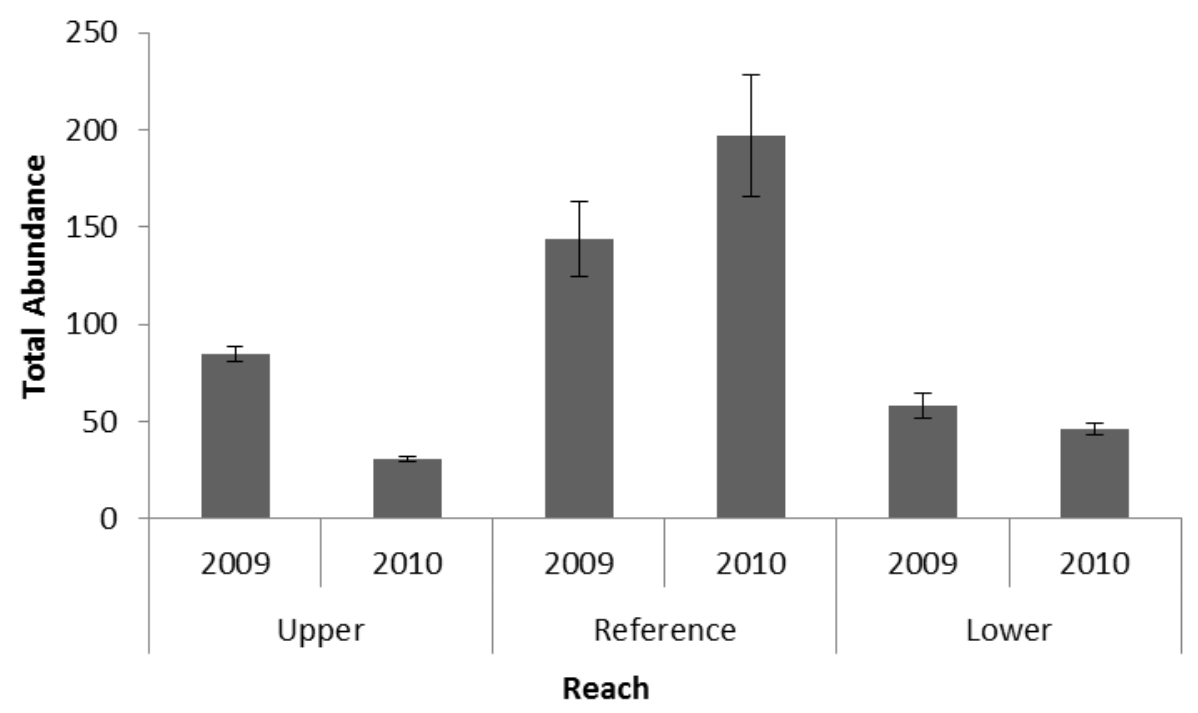

Figure 32. Total fish abundance collected by year and reach with standard error bars. 


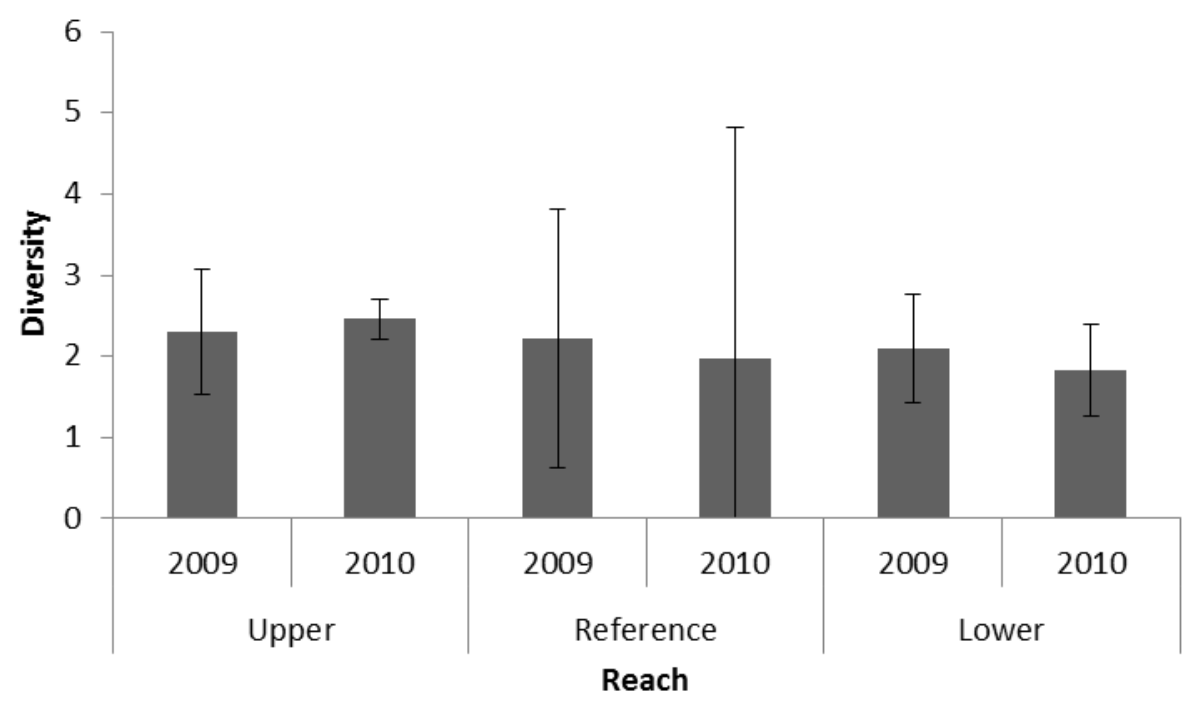

Figure 33. Shannon-Weiner Index of fish diversity by year and reach with standard errors bars. 


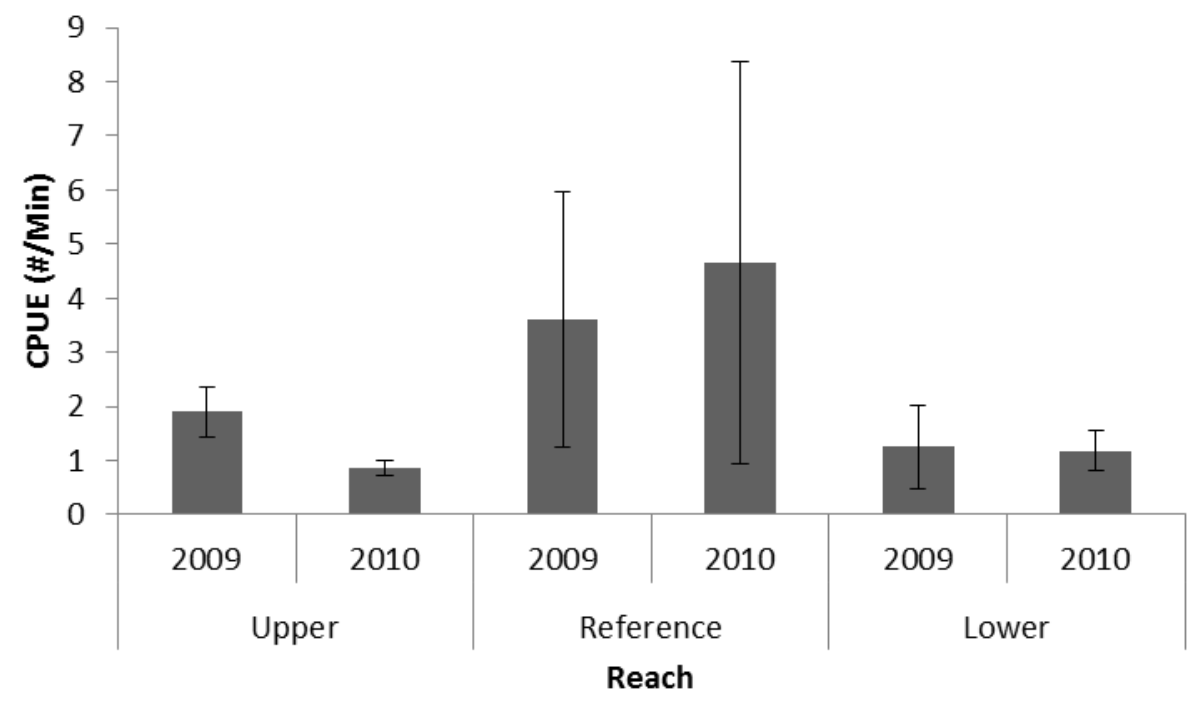

Figure 34. Fish catch per unit effort (fish/minute) by year and reach with standard error bars. 
Table 14. Fish results of $2 \times 3$ factorial analysis of variance (ANOVA), highlighted values indicate results that are significant at the $90 \%$ confidence level).

\begin{tabular}{lllll}
\hline Variable & & Df & F-value & P-value \\
\hline Total Abundance & & & & \\
& Reach & 2 & 1.52 & 0.239 \\
& Year & 1 & 0.01 & 0.945 \\
& Reach x Year & 2 & 0.26 & 0.773 \\
Total Diversity & & & & \\
& Reach & 2 & 4.58 & 0.021 \\
& Year & 1 & 1.75 & 0.198 \\
$\quad$ Reach x Year & 2 & 0.70 & 0.508 \\
Game Fish Abundance & & & \\
& Reach & 2 & 0.57 & 0.575 \\
& Year & 1 & 6.30 & 0.019 \\
$\quad$ Reach x Year & 2 & 1.76 & 0.193 \\
Non-Game Fish Abundance & & & \\
$\quad$ Reach & 2 & 1.43 & 0.26 \\
$\quad$ Year & 1 & 0.00 & 0.971 \\
& Reach x Year & 2 & 0.22 & 0.806 \\
\hline
\end{tabular}


Appendix 1: Genera level macroinvertebrate habitat weighted scores with respect to year and reach.

\begin{tabular}{|c|c|c|c|c|c|c|}
\hline \multirow[t]{2}{*}{ Genera } & \multicolumn{2}{|c|}{ Upper } & \multicolumn{2}{|c|}{ Reference } & \multicolumn{2}{|c|}{ Lower } \\
\hline & 2009 & 2010 & 2009 & 2010 & 2009 & 2010 \\
\hline Oligochaeta & 7.72 & 8.08 & 2.17 & 6.63 & 0.85 & 5.36 \\
\hline Hirudinidae & $\cdot$ & $\cdot$ & $\cdot$ & $\cdot$ & $\cdot$ & 0.01 \\
\hline Clams & 10.08 & 7.30 & 5.49 & 22.13 & 2.53 & 9.56 \\
\hline Snails & 2.94 & 1.80 & 2.65 & 2.19 & 0.63 & 1.47 \\
\hline Cambaridae & $\cdot$ & $\cdot$ & $\cdot$ & $\cdot$ & $\cdot$ & 0.04 \\
\hline Gammaridae & $\cdot$ & 0.01 & $\cdot$ & $\cdot$ & $\cdot$ & 0.08 \\
\hline Caecidotea & 0.02 & $\cdot$ & . & . & . & $\cdot$ \\
\hline Baetidae(UNK) & $\cdot$ & . & 0.16 & $\cdot$ & . & . \\
\hline Accentrella & . & 1.35 & $\cdot$ & 0.37 & 0.01 & 0.10 \\
\hline Baetis & 2.61 & 60.52 & 3.83 & 14.40 & 1.52 & 4.90 \\
\hline Caenis & 0.02 & 0.03 & 0.06 & $\cdot$ & 0.01 & $\cdot$ \\
\hline Heptageniidae(UNK) & 0.86 & $\cdot$ & 0.40 & . & 0.29 & . \\
\hline Epeorus & $\cdot$ & . & 0.01 & . & 0.01 & . \\
\hline Heptagenia & $\cdot$ & $\cdot$ & $\cdot$ & $\cdot$ & 0.07 & $\cdot$ \\
\hline Stenonema & 11.70 & 4.82 & 4.62 & 1.75 & 6.78 & 4.57 \\
\hline Isonychia & 8.65 & 8.34 & 2.39 & 3.05 & 5.59 & 3.89 \\
\hline Leptophelbiidae(UNK) & $\cdot$ & $\cdot$ & 1.47 & $\cdot$ & $\cdot$ & $\cdot$ \\
\hline Ephemerellidae(UNK) & . & $\cdot$ & $\cdot$ & $\cdot$ & 0.01 & $\cdot$ \\
\hline Ephemerella & . & $\cdot$ & 0.17 & $\cdot$ & $\cdot$ & . \\
\hline Drunella & . & 0.01 & $\cdot$ & 0.01 & 0.01 & $\cdot$ \\
\hline Dannella & . & $\cdot$ & $\cdot$ & $\cdot$ & $\cdot$ & 0.02 \\
\hline Eurylophella & . & 0.03 & 0.01 & 0.01 & 0.04 & $\cdot$ \\
\hline Ameletus & $\cdot$ & $\cdot$ & $\cdot$ & $\cdot$ & 0.01 & $\cdot$ \\
\hline Tricorythalus & 437.35 & 331.95 & 189.59 & 236.09 & 229.71 & 238.36 \\
\hline Unknown Mayfly & 0.25 & $\cdot$ & 0.09 & $\cdot$ & 0.01 & 0.08 \\
\hline Hydropsychidae(UNK) & 0.66 & 0.59 & 0.02 & $\cdot$ & 0.75 & 0.08 \\
\hline Parapsyche & $\cdot$ & $\cdot$ & 0.03 & $\cdot$ & $\cdot$ & $\cdot$ \\
\hline Hydropsyche & 4.66 & 9.47 & 0.59 & 2.94 & 0.07 & 3.05 \\
\hline Diplectrona & $\cdot$ & $\cdot$ & 0.13 & $\cdot$ & 0.07 & $\cdot$ \\
\hline Ceratopsyche & $\cdot$ & $\cdot$ & $\cdot$ & $\cdot$ & $\cdot$ & 0.07 \\
\hline Cheumatopsyche & 21.45 & 102.84 & 27.74 & 43.87 & 15.39 & 32.48 \\
\hline Wormaldia & $\cdot$ & $\cdot$ & 0.01 & $\cdot$ & $\cdot$ & $\cdot$ \\
\hline Chimarra & $\cdot$ & 0.41 & $\cdot$ & 0.08 & . & 0.01 \\
\hline Rhyacophilla & $\cdot$ & 0.28 & 0.01 & $\cdot$ & $\cdot$ & 0.08 \\
\hline Polycentropus & 0.05 & 0.25 & 0.03 & 0.01 & 0.01 & 0.02 \\
\hline
\end{tabular}




\begin{tabular}{|c|c|c|c|c|c|c|}
\hline Cyrnellus & $\cdot$ & 0.01 & 0.01 & 0.03 & $\cdot$ & . \\
\hline Lepidostoma & 0.02 & $\cdot$ & $\cdot$ & $\cdot$ & $\cdot$ & . \\
\hline Leptoceridae(UNK) & $\cdot$ & . & . & . & . & 0.01 \\
\hline Oecetis & $\cdot$ & 2.48 & $\cdot$ & 0.94 & $\cdot$ & 0.47 \\
\hline Leptocerus & $\cdot$ & $\cdot$ & $\cdot$ & $\cdot$ & 0.01 & $\cdot$ \\
\hline Hydroptila & 5.34 & 10.84 & 1.96 & 15.88 & 0.58 & 8.76 \\
\hline Orthotrichia & 1.72 & $\cdot$ & $\cdot$ & $\cdot$ & $\cdot$ & 0.02 \\
\hline Ochrotrichia & $\cdot$ & $\cdot$ & $\cdot$ & 0.02 & $\cdot$ & $\cdot$ \\
\hline Palaeagapetus & 0.12 & $\cdot$ & . & $\cdot$ & . & $\cdot$ \\
\hline Leucotrichia & $\cdot$ & 0.01 & . & 0.10 & . & 0.01 \\
\hline Stactobiella & $\cdot$ & $\cdot$ & $\cdot$ & 0.08 & $\cdot$ & $\cdot$ \\
\hline Glossosoma & $\cdot$ & $\cdot$ & 0.02 & $\cdot$ & 0.01 & $\cdot$ \\
\hline Brachycentrus & . & 1.07 & $\cdot$ & 1.00 & $\cdot$ & 0.86 \\
\hline Psychomyia & . & 1.51 & . & 0.77 & . & 1.68 \\
\hline UnkownCaddisfly & 3.82 & $\cdot$ & 2.44 & 0.49 & 0.87 & 0.02 \\
\hline Plecoptera(UNK) & $\cdot$ & . & $\cdot$ & $\cdot$ & 0.01 & $\cdot$ \\
\hline Chloroperlidae(UNK) & 0.37 & 0.11 & $\cdot$ & · & $\cdot$ & 0.01 \\
\hline Utaperla & 0.12 & $\cdot$ & 0.47 & . & . & $\cdot$ \\
\hline Alloperla & $\cdot$ & 0.01 & $\cdot$ & . & . & . \\
\hline Leuctridae(UNK) & . & $\cdot$ & 0.08 & . & . & . \\
\hline Leuctra & 0.74 & 2.31 & 0.59 & 0.51 & 0.06 & 0.68 \\
\hline Perlidae(UNK) & $\cdot$ & 1.39 & 0.02 & 0.11 & 1.50 & 0.21 \\
\hline Acroneuria & 0.10 & 0.06 & 0.19 & 0.13 & 0.01 & 0.01 \\
\hline Neoperla & 0.003 & $\cdot$ & $\cdot$ & $\cdot$ & $\cdot$ & $\cdot$ \\
\hline Perlodidae(UNK) & 1.23 & 0.08 & $\cdot$ & . & . & 0.03 \\
\hline Remenus & $\cdot$ & $\cdot$ & 0.09 & . & 0.01 & $\cdot$ \\
\hline Diploperla & 0.02 & $\cdot$ & $\cdot$ & $\cdot$ & $\cdot$ & $\cdot$ \\
\hline Peltoperla & $\cdot$ & 0.23 & $\cdot$ & . & . & . \\
\hline Nemouridae(UNK) & $\cdot$ & $\cdot$ & 0.02 & . & . & $\cdot$ \\
\hline Amphinemuera & $\cdot$ & 0.17 & $\cdot$ & $\cdot$ & . & $\cdot$ \\
\hline Taeniopteryx & 0.25 & 10.06 & 0.73 & 3.48 & $\cdot$ & 2.93 \\
\hline Unknown Stonefly & 1.35 & 0.11 & 0.63 & $\cdot$ & 0.35 & 0.01 \\
\hline Gomphidae(UNK) & $\cdot$ & $\cdot$ & $\cdot$ & 0.08 & $\cdot$ & $\cdot$ \\
\hline Gomphus & 0.15 & 0.38 & 0.04 & 0.12 & 0.13 & 0.36 \\
\hline Lanthus & 0.18 & 0.03 & $\cdot$ & 0.01 & $\cdot$ & 0.04 \\
\hline Progomphus & 0.09 & 0.02 & 0.09 & $\cdot$ & 0.17 & 0.06 \\
\hline Stylogomphus & 0.02 & $\cdot$ & 0.01 & 0.01 & $\cdot$ & 0.02 \\
\hline Arigomphus & 0.03 & $\cdot$ & $\cdot$ & $\cdot$ & $\cdot$ & $\cdot$ \\
\hline Cordulegaster & $\cdot$ & $\cdot$ & . & 0.01 & $\cdot$ & $\cdot$ \\
\hline Aeshna & $\cdot$ & 0.01 & . & $\cdot$ & 0.01 & . \\
\hline Boyeria & . & $\cdot$ & 0.01 & . & 0.01 & 0.09 \\
\hline Calopteryx & $\cdot$ & 0.01 & 0.01 & 0.01 & $\cdot$ & $\cdot$ \\
\hline Libellulidae & . & $\cdot$ & 0.03 & $\cdot$ & . & . \\
\hline
\end{tabular}




\begin{tabular}{|c|c|c|c|c|c|c|}
\hline Bezzia & $\cdot$ & $\cdot$ & 0.01 & $\cdot$ & $\cdot$ & · \\
\hline Enallagma & 0.02 & . & 0.19 & 0.01 & . & . \\
\hline Nehalennia & 0.14 & . & $\cdot$ & $\cdot$ & . & . \\
\hline Chromagrion & 0.02 & . & . & $\cdot$ & . & . \\
\hline Coenagrionidae(UNK) & 0.02 & . & $\cdot$ & 0.11 & 0.01 & 0.12 \\
\hline Amphiagrion & $\cdot$ & . & . & $\cdot$ & 0.01 & $\cdot$ \\
\hline Unkown Dragonfly & . & 0.01 & 0.08 & 0.01 & $\cdot$ & . \\
\hline Elmidae(UNK) & 0.27 & $\cdot$ & 0.16 & $\cdot$ & $\cdot$ & $\cdot$ \\
\hline Optioservus & 7.14 & 5.96 & 4.70 & 2.47 & 2.25 & 3.19 \\
\hline Oulimnius & 0.74 & 2.48 & 0.48 & 1.06 & 0.26 & 1.00 \\
\hline Ancyronyx & $\cdot$ & 0.01 & $\cdot$ & $\cdot$ & $\cdot$ & 0.01 \\
\hline Microcylloepus & $\cdot$ & 8.51 & $\cdot$ & 8.01 & . & 2.15 \\
\hline Macronychus & 0.03 & $\cdot$ & . & 0.07 & . & $\cdot$ \\
\hline Stenelmis & 0.37 & 9.61 & 0.04 & 2.96 & . & 4.70 \\
\hline Dubiraphia & 0.44 & 3.43 & 0.32 & 0.29 & 0.04 & 1.03 \\
\hline Unknown Beetle & $\cdot$ & $\cdot$ & 0.16 & $\cdot$ & $\cdot$ & $\cdot$ \\
\hline Ectopria & 0.12 & 0.11 & $\cdot$ & $\cdot$ & $\cdot$ & $\cdot$ \\
\hline Psephenus & 0.14 & 0.28 & . & 0.01 & 0.01 & 0.03 \\
\hline Anchytarsus & $\cdot$ & $\cdot$ & $\cdot$ & $\cdot$ & $\cdot$ & 0.01 \\
\hline Curculionidae(UNK) & . & 0.03 & . & . & . & 0.01 \\
\hline Dytiscidae(UNK) & . & 0.04 & . & . & . & . \\
\hline Staphylinidae(UNK) & . & 0.03 & . & . & . & . \\
\hline Hydrophilidae(UNK) & $\cdot$ & $\cdot$ & $\cdot$ & $\cdot$ & $\cdot$ & 0.01 \\
\hline Helichus & $\cdot$ & 0.03 & . & . & . & 0.06 \\
\hline Dineutus & 0.57 & 0.23 & 0.07 & 0.06 & 0.01 & 0.31 \\
\hline Nigronia & 0.02 & 0.01 & $\cdot$ & 0.01 & $\cdot$ & 0.03 \\
\hline Corydalus & 1.08 & 0.90 & 0.91 & 0.44 & 0.56 & 0.59 \\
\hline Sialis & $\cdot$ & 0.01 & 0.08 & 0.01 & $\cdot$ & 0.01 \\
\hline Pyralidae(UNK) & 0.05 & 0.63 & $\cdot$ & 0.76 & . & 1.65 \\
\hline UknownHemiptera & $\cdot$ & 0.15 & 0.01 & $\cdot$ & . & 0.01 \\
\hline Corixidae & . & $\cdot$ & 0.01 & . & . & $\cdot$ \\
\hline Trepobates & . & $\cdot$ & $\cdot$ & . & . & 0.01 \\
\hline Rhagovelia & . & 0.03 & . & . & . & 0.72 \\
\hline Microvelia & $\cdot$ & 0.04 & $\cdot$ & $\cdot$ & $\cdot$ & 0.23 \\
\hline Chironomidae & 24.83 & 147.87 & 20.03 & 88.33 & 7.43 & 72.78 \\
\hline Tipulidae(UNK) & 0.12 & $\cdot$ & 0.57 & $\cdot$ & . & $\cdot$ \\
\hline Antocha & 0.25 & 0.77 & 0.08 & 1.35 & $\cdot$ & 1.31 \\
\hline Tipula & 0.81 & 0.50 & 0.70 & 0.67 & 0.12 & 0.50 \\
\hline Hexatoma & 0.02 & $\cdot$ & $\cdot$ & $\cdot$ & $\cdot$ & 0.01 \\
\hline Molophilus & $\cdot$ & . & . & . & . & 0.01 \\
\hline Limnophila & 0.05 & . & . & . & . & $\cdot$ \\
\hline Tabanus & $\cdot$ & 0.004 & $\cdot$ & $\cdot$ & $\cdot$ & $\cdot$ \\
\hline Simulium & 6.10 & 12.75 & 2.38 & 2.16 & 0.55 & 9.28 \\
\hline
\end{tabular}




\begin{tabular}{|c|c|c|c|c|c|c|}
\hline Atherix & 2.32 & 0.23 & 0.61 & 0.02 & . & . \\
\hline Empididae(UNK) & · & 0.77 & $\cdot$ & 0.52 & . & 0.15 \\
\hline Chelifera & . & 0.59 & . & 0.31 & . & . \\
\hline Hemerodromia & . & 4.45 & 0.02 & 2.35 & 0.23 & 1.85 \\
\hline Ceratopogonidae(UNK) & $\cdot$ & $\cdot$ & $\cdot$ & $\cdot$ & 0.01 & 0.07 \\
\hline Bezzia & 0.04 & 0.65 & 0.50 & 2.00 & 0.06 & 0.43 \\
\hline Dasyhelea & $\cdot$ & 0.56 & $\cdot$ & 0.17 & $\cdot$ & $\cdot$ \\
\hline Atrichopogon & . & $\cdot$ & . & 0.01 & . & 0.09 \\
\hline Unknown Diptera & 0.58 & · & 0.43 & · & 0.25 & 0.16 \\
\hline Neophylax & $\cdot$ & . & 0.31 & . & $\cdot$ & · \\
\hline Hydracarina & 1.48 & 30.20 & $\cdot$ & 24.63 & 0.17 & 20.39 \\
\hline Aphididae(UNK) & $\cdot$ & 0.28 & . & 0.80 & $\cdot$ & 0.84 \\
\hline Agreniabidenticulata & 0.12 & 0.07 & 0.08 & 0.94 & 0.06 & 0.07 \\
\hline UNK Isotomidae & 0.03 & $\cdot$ & 0.14 & $\cdot$ & 0.09 & . \\
\hline Thaumaleidae(UNK) & $\cdot$ & . & $\cdot$ & . & 0.02 & . \\
\hline Baetisca & $\cdot$ & 0.01 & . & $\cdot$ & $\cdot$ & 0.08 \\
\hline Cyclopoida & . & $\cdot$ & . & 0.07 & . & $\cdot$ \\
\hline
\end{tabular}

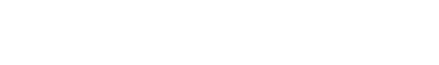

